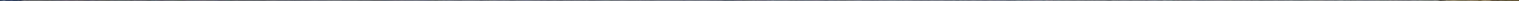



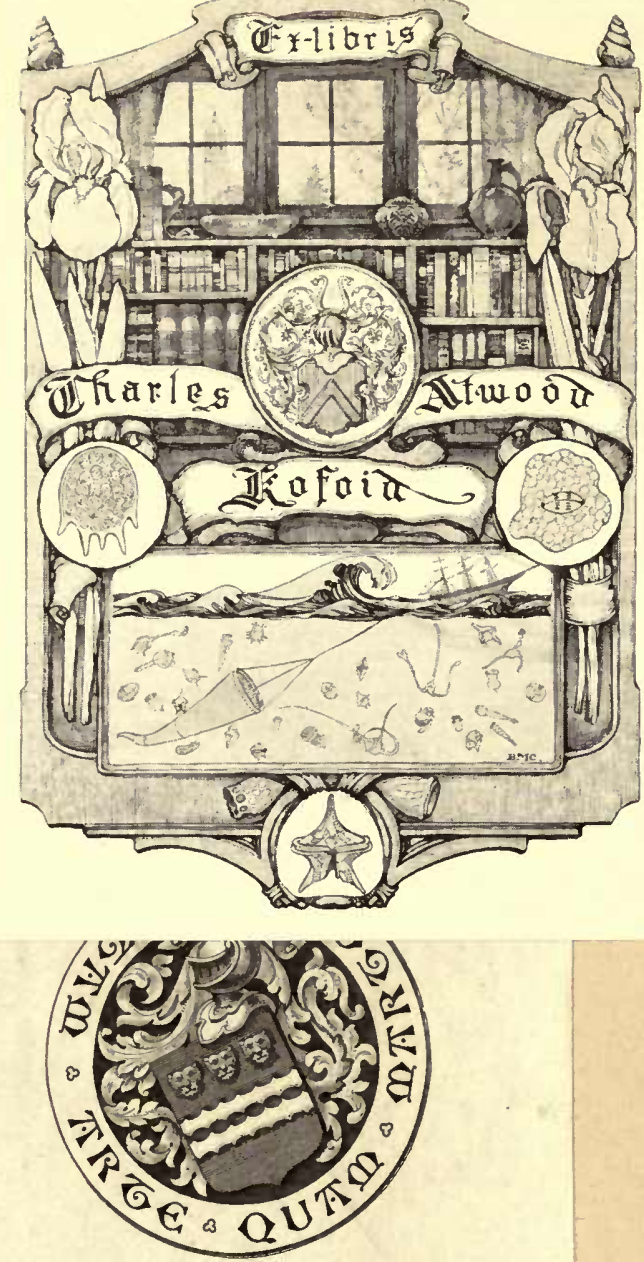

fohn Havery Whight. 

Edinburgh

Printed by Porteous \& Denholm

Elder Street 



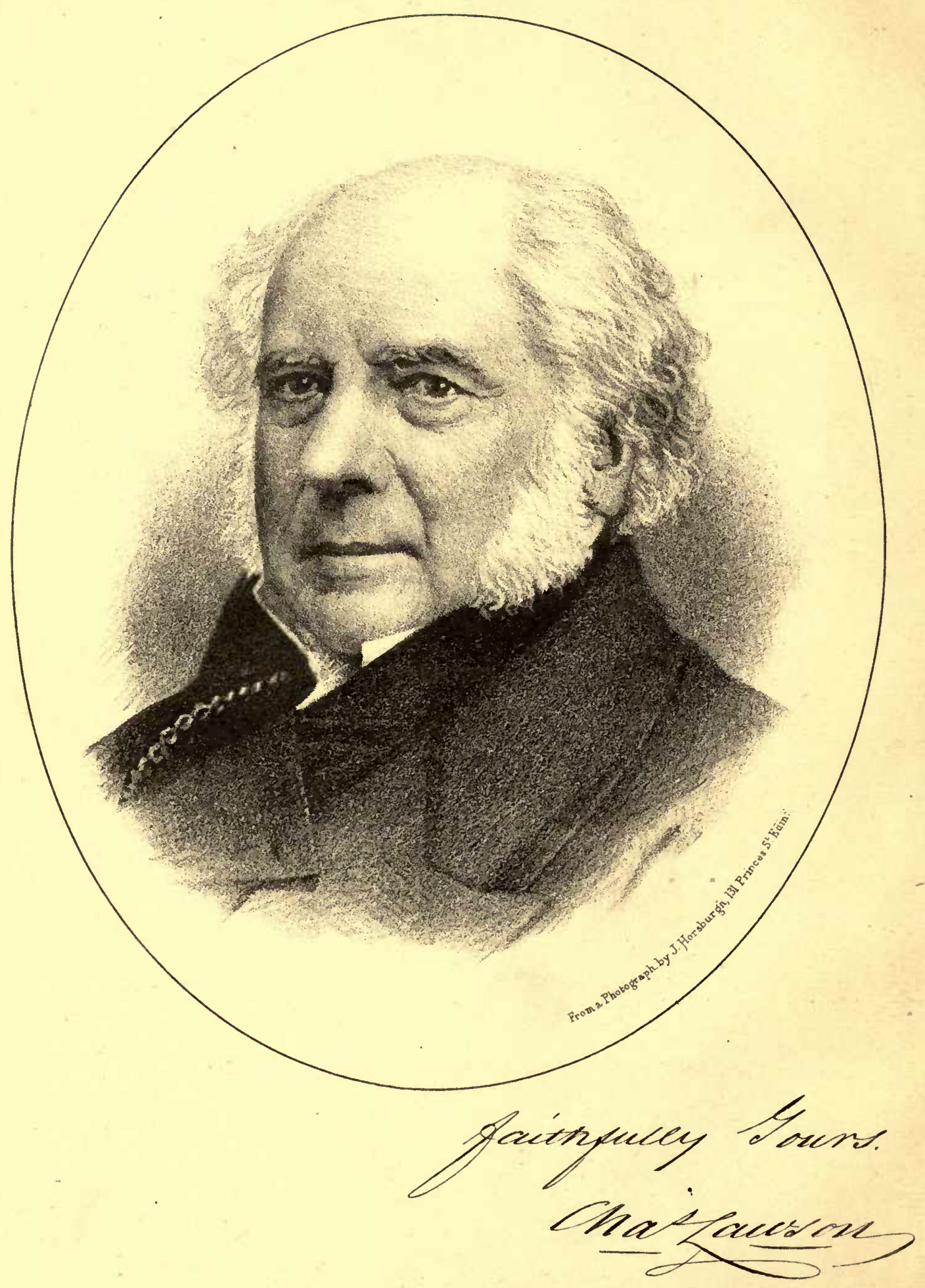




\section{AGROSTOGRAPHIA}

A TREATISE ON THE

\section{ULTIVATED GRASSES}

AND OTHER

\section{HERBAGE AND FORAGE PLANTS}

THE LAWSON SEED AND NURSERY COMPANY (LIMITED) SUCCESSORS TO PETER LAWSON AND SON (The Qucen's Seedsmen, etc., etc.)

WILLIAM BLACKWOOD \& SONS

EDINBURGH AND LONDON

1877 
Monographers, come from whence they may, have, I think, fair pretence to challenge some regard and approbation from the lovers of Natural History; for as no man can alone investigate all the works of Nature, these partial writers may each in his department be more accurate in their discoveries and freer from errors than more general writers, and so by degrees may pave the way to a universal correct Natural History.-GILBERT WhITE. 
013147

43

1877

$\overline{\mathrm{M}} 320583$ 


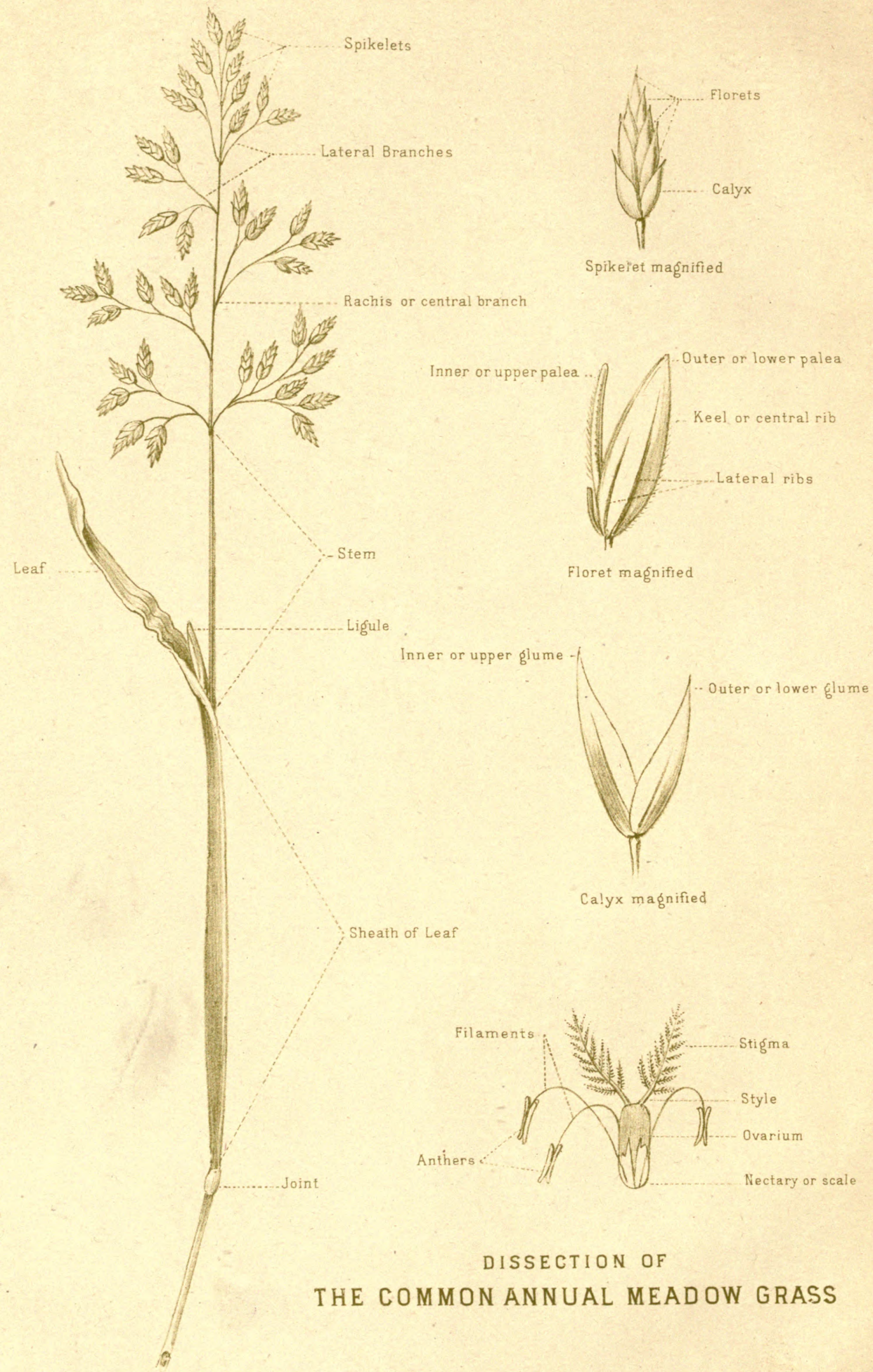




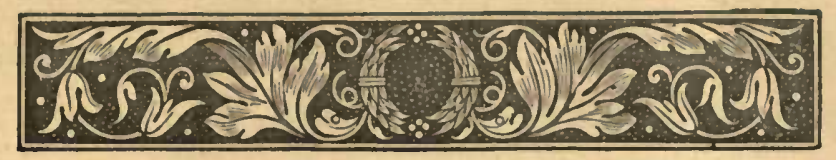

\section{PREFACE TO THE FOURTH EDITION}

(Published in 1853)

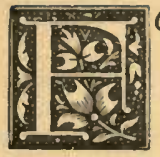

$O R$ more than forty years the attention of the Authors has been particularly directed to that branch of Agriculture which comprises the cultivation of the Grasses and other Herbage and Forage Plants used for Pasturing and Feeding Cattle. Twenty years ago (in I833) they drew up the results of their accumulated observations and experiments, with accompanying Tables, specifying the kinds and quantities of Seeds necessary to be sown for securing proper Pasturage: which observations were, the following year, published in the "Quarterly Journal of Agriculture." In I836, after undergoing revision, these Tables were republished in the "Agriculturist's Manual."

A continuation of careful and minute trials and comparisons led them, in 1842 , again to revise these Tables, which were then embodied in the First Edition of the present Treatise, a Second Edition of which was called for in 1846, and a Third in 1850. The circulation of three large editions of a practical Treatise on Grasses proves, at least, that considerable attention is now paid to this important subject; and the Authors would fain hope that their efforts to diffuse useful information on this branch of Agriculture have, in some degree, been the means of bringing about so satisfactory a result.

A Fourth Edition being now called for, the Authors have, with the view of rendering it of still greater utility, bestowed considerable care in its preparation. All the Tables have been carefully revised, and in some instances reconstructed, and now embody the results of their long experience and extended experiments. The descriptions of the various Natural and Artificial Grasses have been entirely rewritten, and embrace all that is useful or interesting regarding 
their nature and habits, the particular soils for which they are adapted, and the peculiar curcumstances under which their culture is necessary or desirable. The engravings explanatory of the different parts of a Grass, botanically distinguished, will, it is hoped, be found useful, enabling the farmer to understand the scientific terms used in the Treatise, and which cannot always be avoided in describing a plant.

It may, perhaps, be as well to notice here, that, as the herbage of Pastures is infuenced by the different kinds of soils, especially with relation to their states of dryness or wetness, the Tables have, for practical purposes been constructed in three divisions, viz., Grasses for light soils, for medium soils, and for heavy soils. The light embrace soils more or less of a sandy or gravelly nature; the heavy soils include clay and heavy loams; while the medium are to be regarded as an intermediate class between these two extremes. A light wet soil, with respect to the Grasses suited to it, may be considered as approximating to the heavy soils, and a dry heavy soil as approaching towards the light soils.

\section{PREFACE TO THE FIFTH EDITION}

(Published in 1855)

The present Edition has been very carefully revised, and some errors corrected and omissions supplied. The Table of English Names at the end has been reconstructed, and now serves as a general index to the work. A Table is likewise appended shewing the times of flowering and of ripening seeds of all Cultivated Grasses, which it is considered may be found useful to the observing Agriculturist. 


\section{PREFACE TO THE SIXTH EDITION}

HIS well-knozen little work, which has been out of print for a considerable time, being frequently asked for, The Lawson Seed and NuRsery Company have much pleasure in issuing the present edition in a different, but, they trust, not less acceptable form.

There is scarcely anything newe to be said on a subject which has already been so exhaustively treated. There have been no additional introductions of HERBAGE and FORAGE Plants during the past score of years considered worthy of notice here. It is, honezer, remarkable that the cultivation of the most important grasses, to which earnest attention was called many years ago in the early editions of these pages, has increased over the world to an extent little anticipated by the Pioneers in their introduction; several sub-varieties formerly noticed, not being of practical value to the agriculturist, are nowe discarded.

The Tables for regulating the various mixtures of Grass Seeds remain nearly as they were; many years of careful study of the subject, and the almost universal adoption of the system, having demonstrated the wisdom and forethought of their original compilers. The illustrations of leading sorts of grasses form a new feature in the book, and, considering the life-long devotion to, and interest in, this and kindred subjects, evinced by one lately passed away, the Frontispiece may perhaps be considered not inappropriate on this occasion. 



\section{TABLE OF CONTENTS}

\section{CHAPTER I.}

\section{Which treats of the Introduction and Cultivation of Species and Varieties}

Introductory Remarks-Culture of Plants for Cattle Food not attended to in the Early Ages - Cultivation of, commenced in England about the middle of the Seventeenth Century; in Scotland at the beginning of the Eighteenth, and in Ireland from about the middle of the same Century-Publication of the "Hortus Gramineus Woburnensis" in $182 \mathrm{r}$, from which period more particular attention directed to cultivation of Natural Grasses-Important results to be anticipated from extended culture of recently introduced varieties $\quad \ldots \quad \ldots$

\section{CHAPTER II.}

Which enumerates the Kinds and specifies the Quantities of Seeds for Sowing down Land to Pasture

Unaccountable disparity of quantity and proportion of Grass Seeds sown by different cultivators ...

Here follow a series of Tables, shewing the Kinds and Quantities of Grass Seeds required for sowing the Imperial Acre :-

$\begin{array}{llllllllllll}\text { I Alternate Husbandry } & \ldots & \ldots & \ldots & \ldots & \ldots & \ldots & \ldots & \ldots & \ldots & \ldots & \end{array}$

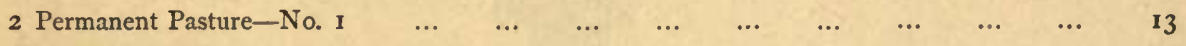

$\begin{array}{llllllllllll}3 & \text { Permanent Pasture-No. } 2 & \ldots & \ldots & \ldots & \ldots & \ldots & \ldots & \ldots & \ldots & \ldots & 14\end{array}$

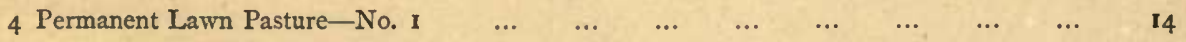

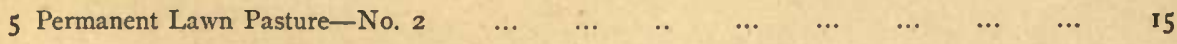

6 Fine Lawns, Croquet Greens, Bowling Greens, Bleaching Greens, \&c., kept constantly $\begin{array}{llllllllllll}\text { under the Scythe } & \ldots & \ldots & \ldots & \ldots & \ldots & \ldots & \ldots & \ldots & \ldots & \ldots & 16\end{array}$

$\begin{array}{lllllllllll}7 \text { Lands in Preparation for Irrigation } & \ldots & \ldots & \ldots & \ldots & \ldots & \ldots & \ldots & \ldots & 16\end{array}$

8 Permanent Pasture and Hay in Orchards and other Grounds much overshadowed by Trees $\quad 17$ 
9 Pasturage and Cover in Thick Snady Woods and Plantations

PAGE

ro Heathy and Moory Lands, which have been Improved with a view to their producing $\begin{array}{llllllllllllll}\text { better Pasturage } & \ldots & \ldots & \ldots & \ldots & \ldots & \ldots & \ldots & \ldots & \ldots & \ldots & \text { I } \delta\end{array}$

II Improved Deep Mossy Ground, intended to be kept in Grass $\quad \ldots \quad \ldots \quad \ldots \quad \ldots \quad \ldots \quad$ I8

I2 For Covering Rocky, Gravelly, and other Soils of the worst description $\ldots \quad \ldots \quad$... $\quad$ 19

I3 Marshy Grounds and those occasionally overflowed by Fresh-Water Tides $\quad \ldots \quad$... $\quad$ I9

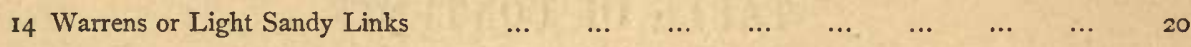

I5 Dry Gravelly situations, which resist a Sward from all ordinary means $\quad \ldots \quad \ldots \quad$.., 20

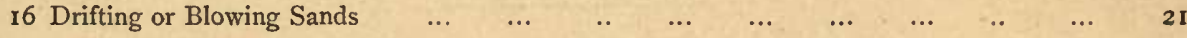

\section{CHAPTER III.}

Which describes, in a popular manner, the Natural and Artificial Grasses

The Natural Grasses described

$\begin{array}{llllllllllllllll}\text { List } \text { of Synonyms } & \ldots & \ldots & \ldots & \ldots & \ldots & \ldots & \ldots & \ldots & \ldots & \ldots & \ldots & \ldots & 33\end{array}$

The ARtrficial Grasses described $\quad \begin{array}{lllllllllllllllll} & \ldots & \ldots & \ldots & \ldots & \ldots & \ldots & \ldots & \ldots & \ldots & 34\end{array}$

Table shewing the average weight per bushel of the seeds of different species and varieties of ...

Grasses, with the average number of Seeds required to weigh one ounce $\quad \ldots \quad \ldots \quad \quad \ldots \quad 40$

$\begin{array}{lllllllllllllll}\text { English Names of the Natural Grasses } & \ldots & \ldots & \ldots & \ldots & \ldots & \ldots & \ldots & \ldots & \ldots & 4 \text { I }\end{array}$

$\begin{array}{lllllllllllllll}\text { English Names of the Artificial Grasses } & \ldots & \ldots & \ldots & \ldots & \ldots & \ldots & \ldots & \ldots & \ldots & 43\end{array}$

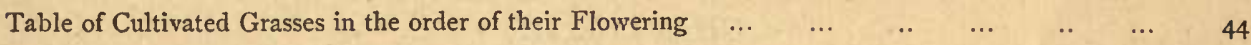




\section{ILLUSTRATIONS}

BY

Horsburgh, Edinburgh

Dissection of the Common Annual Meadow Grass

TO FACE PAGE

Agrostis STOLONIFERA, with magnified calyx and floret

v.

ALOPECURUS PRATENSIS, with magnified spikelets and seeds

ANTHOXANTHUM ODORATUM, with magnified floret and seeds

AVena Flavescens, with magnified floret and seed ... $\quad .$.

CYNOSURUS CRISTATUS, with magnified spikelet and seed $\quad \ldots \quad \ldots \quad \ldots \quad \ldots \quad \ldots \quad \ldots \quad 22$

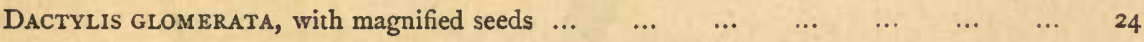

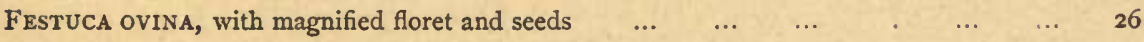

FESTUCA PRATENSIS, with magnified florets and seeds $\quad \begin{array}{llllllllllll} & \ldots & \ldots & \ldots & \ldots & \ldots & 28\end{array}$

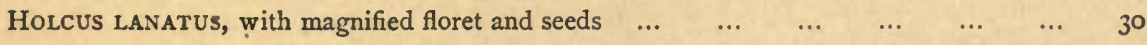

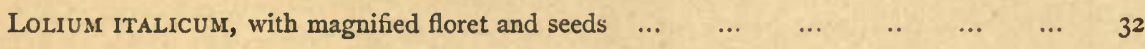

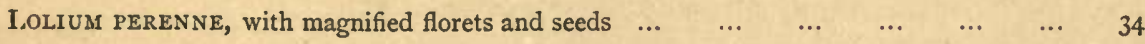

$\begin{array}{lllllllllllllllll}\text { PhLEUM PRATENSE, with magnified florets } & \ldots & \ldots & \ldots & \ldots & \ldots & \ldots & \ldots & 36\end{array}$

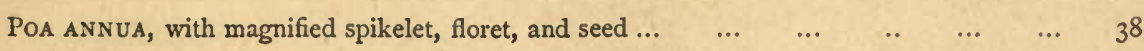

POA PRATENSIs, with magnified spikelet, floret, and seeds $\quad \begin{array}{lllllllllll} & \ldots & \ldots & \ldots & & \ldots & \end{array}$

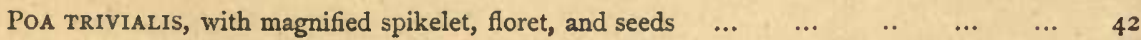




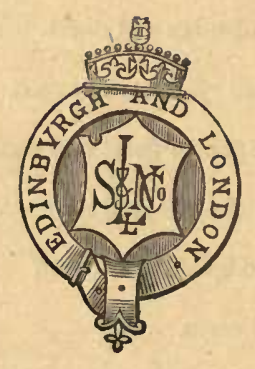




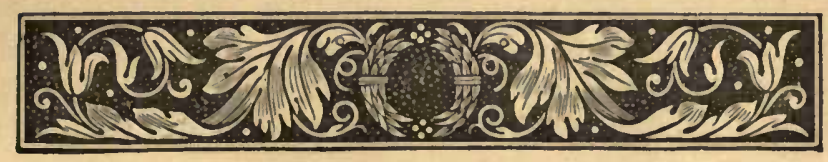

\section{ON THE CULTIVATED GRASSES}

\section{CHAPTER I.}

\section{WHICH TREATS OF THE INTRODUCTION AND CULTIVATION OF SPECIES AND VARIETIES.}

$\mathrm{T}^{\mathrm{H}}$ E Culture of Plants, for the food of domestic herbivorous animals, has always been confined to nations distinguished by advancement in the practice of agriculture, and the other arts attendant on civilisation; thus, we find that branch of husbandry to have been successfully practised by the Romans in the first century; and in the sixteenth it was carried on extensively in the Low Countries-then alike famous for agriculture, manufactures, and commerce-whence it was, about the middle of the seventeenth century, introduced to Britain, where its practice may be said to have served as an index to determine the progressive advancement of agriculture from that to the present time. It is therefore hoped that the following short outline of its history may not be deemed entirely devoid of interest.

Although the Egyptians, Jews, Greeks, and other eminent nations of antiquity, bestowed considerable care on the culture of the cereal grains, pulse, flax, and various other plants, the products of which conduced to the alleviation of their personal wants, by affording either food or clothing; and although the possession of flocks and herds was, among many of those nations, deemed indicative both of power and honour, yet it does not appear that the cultivation of plants for the exclusive purpose of feeding cattle was practised prior to the period when Rome swayed the sceptre over the greater part of the then known world-when her warriors and senators enjoyed, in the culture of their lands, relaxation from the dangers of the battle-field, or the cares of the state; and when, according to an eminent agricultural writer of that age, "the earth delighted to be ploughed with a share adorned with laurels; and by a ploughman who had been lonoured with a triumph." Then, in the times which immediately preceded the decline of that mighty empire, the Romans not only grew wheat, far or spelt, barley, beans, etc., for bread, but they also cultivated Lucern, Red Clover, Vetches, Lupines, Fenugreek, and other leguminous plants, which they used both in a green and a dried state for feeding their live stock; and for a like purpose they also employed the turnip and rape; while their horses and working oxen were further regaled with the ripened seeds of the cerealia, as well as those of the bean, pea, and other leguminosæ. But throughout the barbarous ages which succeeded the ruin of the Roman empire, it may, in the absence of any definite information, be safely inferred that, with the decline of agriculture, and the useful arts generally, that portion in the practice of the former which alone tended to supply the wants of the 
domestic animals, was the first to fall into disuse; and if the growth of clover, lucern, and other plants, was at all continued, it must have been to a very limited extent, and confined most likely to the countries where their usefulness was formerly most generally appreciated.

In England, while hemp, flax, hops, and buckwheat, in addition to common wheat, rye, and barley, were, in the sixteenth century, reckoned common crops; yet the cultivation of forage or herbage plants was only commenced about the middle of the seventeenth century, with the exception of Summer* and Winter $\uparrow$ Tares or vetches, which are mentioned by the earliest writers on agriculture. John Gerarde, the famous herbalist, surgeon, and traveller, of the days of Queen Elizabeth, states, in his "General History of Plants," published in I597, that "the Red Clover was sown in the fields of the Low Countries, in Italy, and divers other places beyond the seas," but makes no mention of it being then known in England; and Sir Richard Weston, who, in 1645 , published his " Travels in Flanders," mentions that, in the preceding year, he saw a crop of it cut three times in the course of the summer, in the vicinity of Antwerp; and immediately thereafter, seeds of the "Great Clover of Flanders" + were advertised "to be had at the shop of James Long, at the Barge on Billingsgate." In 1653 , Walter Blyth, an agricultural writer, was the first to publish particular directions as to its culture; so that the merit of its primary introduction to England is generally ascribed to Sir Richard Weston, who is also believed to have first introduced, from the same country, the field culture of turnips, on his return, in 1645 . Sainfoin $\S$ or, as it was first named, French fingergrass, seems to have been introduced from France in $\mathbf{r}_{5} \mathrm{I}$. According to Miller, author of the "Gardener's Dictionary," Lucern\| was also brought to England, from the same country, in 1657 . Hartlib, in his "Complete Husbandman," published in 1659, recommends the sowing of Nonsuch or yellow clover, under the name of hop-trefoil, from having seen a chalky down in Kent, without any other than a scanty vegetation of this plant, "maintaining many great sheep and very lusty, so that they were even fit for the butcher."

The seventeenth century is further distinguished, in the annals of husbandry, by the first cultivation of any of the true grasses for hay or pasture, which is thus recorded in Dr Plot's "Oxfordshire," published in 1677 : "They have lately sown Ray-grass,** or the Gramen loliaceum, by which they improve any cold, sour, clay-weeping ground, for which it is best, but good also for drier upland grounds, especially light, stony, or sandy land, which is unfit for sainfoin. It was first sown in the chiltern parts of Oxfordshire, and since brought nearer Oxford by one Eustace, an ingenious husbandman of Islip, who, though at first laughed at, has since been followed even by those very persons that scorned his experiments." Succeeding writers, however, do not fail to condemn the ryegrass as an impoverisher of the soil, while they affirm that its hay is not to be compared to that of clover or sainfoin; the former of which seems alone to have had any particular attention bestowed upon it till the following century. Ray, in his " History of Plants," published in I688, mentions that the Yellow Melilot $\dagger+$ was then sometimes sown for the food of kine and horses; but succeeding writers generally include it among agricultural weeds. And lucern, although introduced, was scarcely, if at all, subjected to field-culture prior to the seventeenth century.

Mr Lisle, author of "Observations on Husbandry," written in I707, states that then

* Vicia sativa astiva

|| Medicago sativa
+ Vicia sativa hyberna

TI Medicago lupulina
¥ Trifolium pratense ** Lolium perenne
$\S$ Onobrychis sativa + Melilotis officinalis 


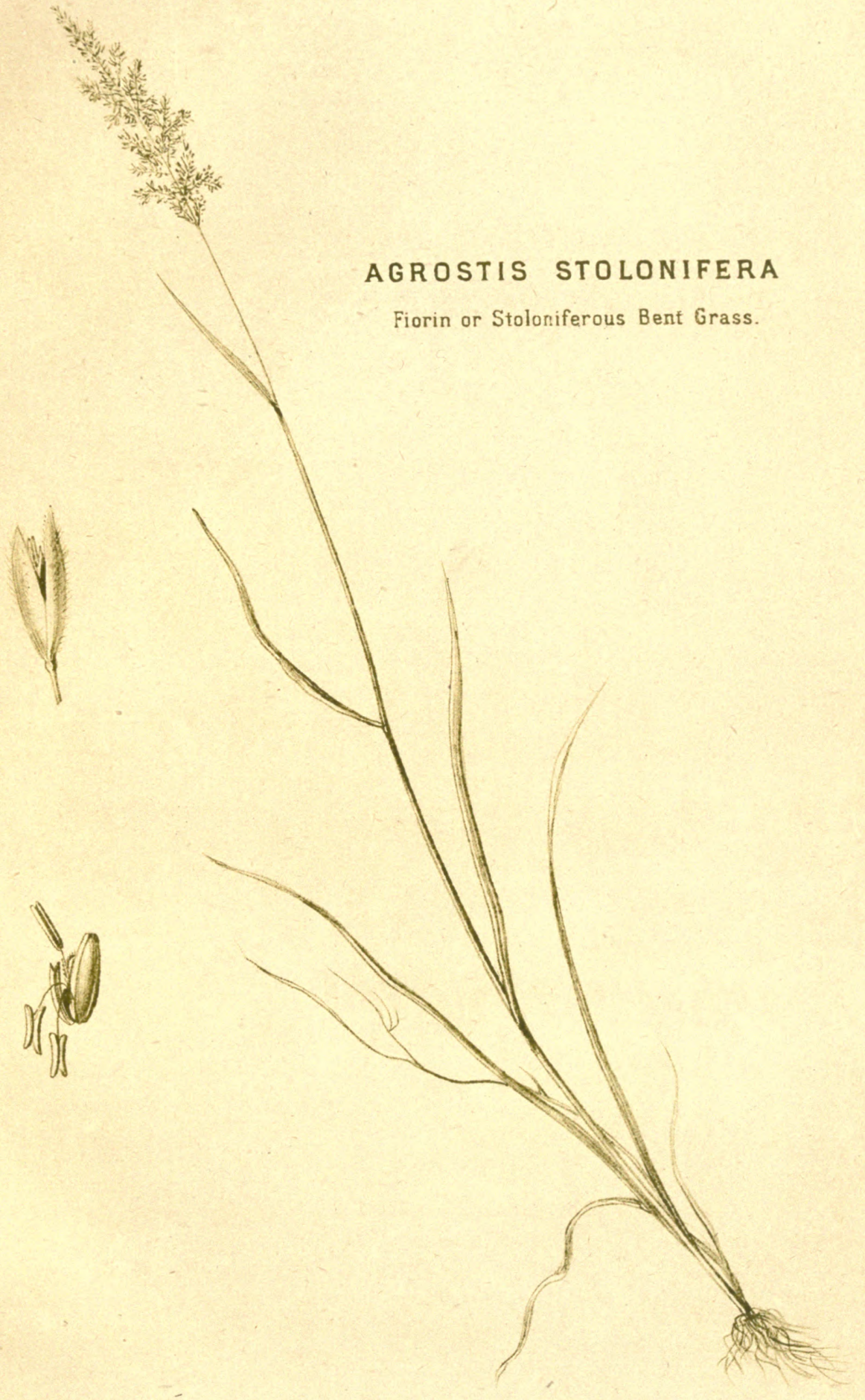



clover was commonly cultivated in Wiltshire, Hampshire, Gloucestershire, Leicestershire, Sc.; also, that of late years the Cow-grass* had obtained some credit as a longer-lived sort than the common clover; and he further mentions that a neighbour in Hampshire had "sowed the wild White clover $\nmid$ which holds the ground and decays not," the seeds of which he received from Sussex, where its culture was then practised. Mortimer, who, in I72I, published his "Whole Art of Husbandry," relates that "in Buckinghamshire they make great improvement of their lands by sowing them with Parsley; $\ddagger$ which prevents the rot of sheep;" and that "one in the hundreds of Essex made a great improvement of some land by sowing of it with Mustard-seed, $\$$ for the same purpose."

The next novelty in English field-culture seems to have been the Whin,\| as appears by a letter from Colonel Charles Cathcart, to the Scottish Society for Improving in the Knowledge of Agriculture, dated London, 6th April 1725, in which he mentions that "the sowing of whins for feeding of cattle takes mightily about London now ;" and that "this improvement comes from Wales, where it has been practised these hundred years." In I 744, William Ellis, a Herefordshire farmer, published his "Modern Husbandman," in which he claims the merit of introducing the culture of the Wild "Thetch-grass," or Mousetare, and the "lady finger-grass," or Birds-foot Trefoil, ** which he "affirms for truth are the two best sorts of natural meadow-grasses that are for feeding and fattening of conies, deer, race-horses, or any other sort of cattle that will eat them in grass or hay ;" and adds, that "if gentlemen knew the value of them they would have no occasion for searching after a foreign Spurry $\dagger \dagger$ seed, which I have experienced exceeds all others for its worthless nature;" from which, and other passages, it appears that the culture of spurry was introduced from Holland about I740. And the same author mentions, that he " had heard of a "gentleman in a distant country who had sowed the plantain-seed," or Rib-grass, $¥+$ but was unable to state the results; which seems the first notice taken by English writers of a plant that afterwards received much more attention than, in the present opinion of agriculturists, its merits ever deserved. In the "Farmer's Complete Guide," published in I 760, attention is directed to the "new Lucerne," or sickle-podded medick, $\$ \S$ which the writer states to be " a native of Herefordshire and the adjoining counties, but where it is by no means common;" and further adds, that "the Swedes derive great advantages from its culture." Succeeding authors relate that Burnet|| || was first grown as a field plant in 1760 , or $176 \mathrm{r}$, by Mr B. Rocque of Wolham, Green, at the suggestion of $\mathrm{Mr}$ Peter Wyche, to whom belongs the merit of introducing from America, about that time, the Timothy-grass, शף first so named in Carolina, from having been taken to that State by a Mr Timothy Hanson; from which country the culture of the orchard-grass, or Cocks-foot, ${ }_{*}^{*}$ was also introduced shortly afterwards, the same $\mathrm{Mr}$ Rocque having grown it in 1764 .

From the preceding, it will be observed with what avidity the earlier cultivators sought out herbage and forage "grasses," as they termed them, among the leguminosæ and other corollaceous plants, and with what seeming care they eschewed the true grasses; their often-repeated reason for which was, that "these produced many small hair-like roots which filled the soil, and, therefore, could not be but very impoverishing and hurtful thereto;" without considering that the then very common practice of cropping a field, as

\footnotetext{
* Trifolium pratense perenne

$\S$ Sinapis (species unascertained)

+ Spergula arvensis

+ Trifolium repens $\quad \pm$ Petroselinum sativum

If Ulex europæus T Ervum hirsutum * Lotus corniculatus

III Poterium sanguisorba

\# Plantago lanceolata $\$ \S$ Medicago falcata

TI Phleum pratense * * Dactylis glomerata.
} 
long as it would recompense their labours, and afterwards letting it alone for some years to recover under a crop of unsown grass, was of itself a perfect contradiction to their false theory.

As an approximation, however, to a more approved system, some recommended sowing, for permanent pasture, seeds shaken out of the best natural meadow-hay, along with the clovers; without considering that, as the different species composing such hay did not ripen their seeds simultaneously, only a partial reproduction of these species could be expected. But the recommendations of Stillingfleet in 1759 , and others immediately thereafter, to cultivate certain of the most useful grasses, as the crested dog's-tail, ${ }^{*}$ sweet vernal, $\dagger$ meadow fox-tail, $\ddagger$ meadow fescue, $§$ sheep's fescue, $\|$ rough and smoothed-stalked meadow-grasses, \&c., by growing their seeds separately; and the successful introduction from America of the timothy and cocksfoot, directed the attention of practical agriculturists to a new source whence to procure a further accession to their hay and pasture plants; and likewise suggested to agricultural writers the expediency of adopting different terms to distinguish between the clovers and true grasses. Accordingly we find that, after that period, they generally denominate the former artificial grasses, and the latter natural grasses.

In $176 \mathrm{I}, \mathrm{Mr}$ Aldworth, of Stanslake, collected, at the suggestion of Mr Stillingfleet, fully a bushel of the seed of the Crested dog's-tail grass; and that author mentions having himself "procured a sufficiency of the same seed, as well as that of the creeping Bent, $\mathbb{1}$ fine bent,** Sheep's fescue, \&c., to begin a stock with." In the same year, the broadleaved Everlasting Pea, +十 was grown by a gentleman who, in the "Museum Rusticum," published in 1765 , states that he then sowed a rood of it, "which yielded a great deal ot feed much relished, both in a green and dried state, by horses and cattle." In I 766, a prize of $£_{5}$ was awarded by the London Society for the Encouragement of Arts, Manufactures, and Commerce to Mr W. Judge, Woodford, Essex, "for gathering by the hand the seeds of Meadow Fox-tail grass ;" as also $£ 5$ and $£ 3$, 3s. to Mr E. Birch, Somerset, and William Gosse, Hants, for collecting, in like manner, the seeds of crested dog's-tail grass; and in the following year Mr Gosse received two further premiums for gathering seeds of the Meadow fescue and Sweet vernal grasses. The same Society, in 1768 , offered a premium of $£$ Io " for the greatest quantity of land (not less than one acre) of vernal grass-seed, sown in drills;" and their gold medal was further offered, in 1769 , "to the person who should give the most satisfactory account of the different properties and comparative value of any two or more of the several natural grasses."

By earlier authors, Yarrow or Milfoil $+\ddagger$ was generally included among pernicious weeds ; but a writer in the "De Re Rustica," published in I 769, strongly recommends the sowing of it in sheep pastures. About $1780, \mathrm{Mr}$ Boys, a farmer of high reputation in Kent, commenced the culture of the Rough-stalked Meadow Grass $\$$; having had, in $\mathrm{x}_{785}$, from twenty to thirty bushels of its seed for sale, which he offered at 3 s. per pound; but was obliged to drop its culture from want of demand. Marshall, in his "Rural Economy of Yorkshire," published in 1788 , states, that "white or meadow soft grass," now better known by the name of Yorkshire Fog, \|\| " was formerly in high esteem, being cultivated separately, and thrashed like corn for its seeds; but it was far from being an eligible grass for cultivation, the growers of the seed being the only persons who profit thereby, eighty

\footnotetext{
* Cynosurus cristatus † Anthoxanthum odoratum ‡ Alopecurus pratensis § Festuca pratensis

H Festuca ovina if Agrostis alba ** Agrostis vulgaris \# Lathyrus latifolius
} $\#_{+}$Achillea Millefolium $\$ \S$ Poa trivialis $\quad\|\|$ Holcus lanatus 


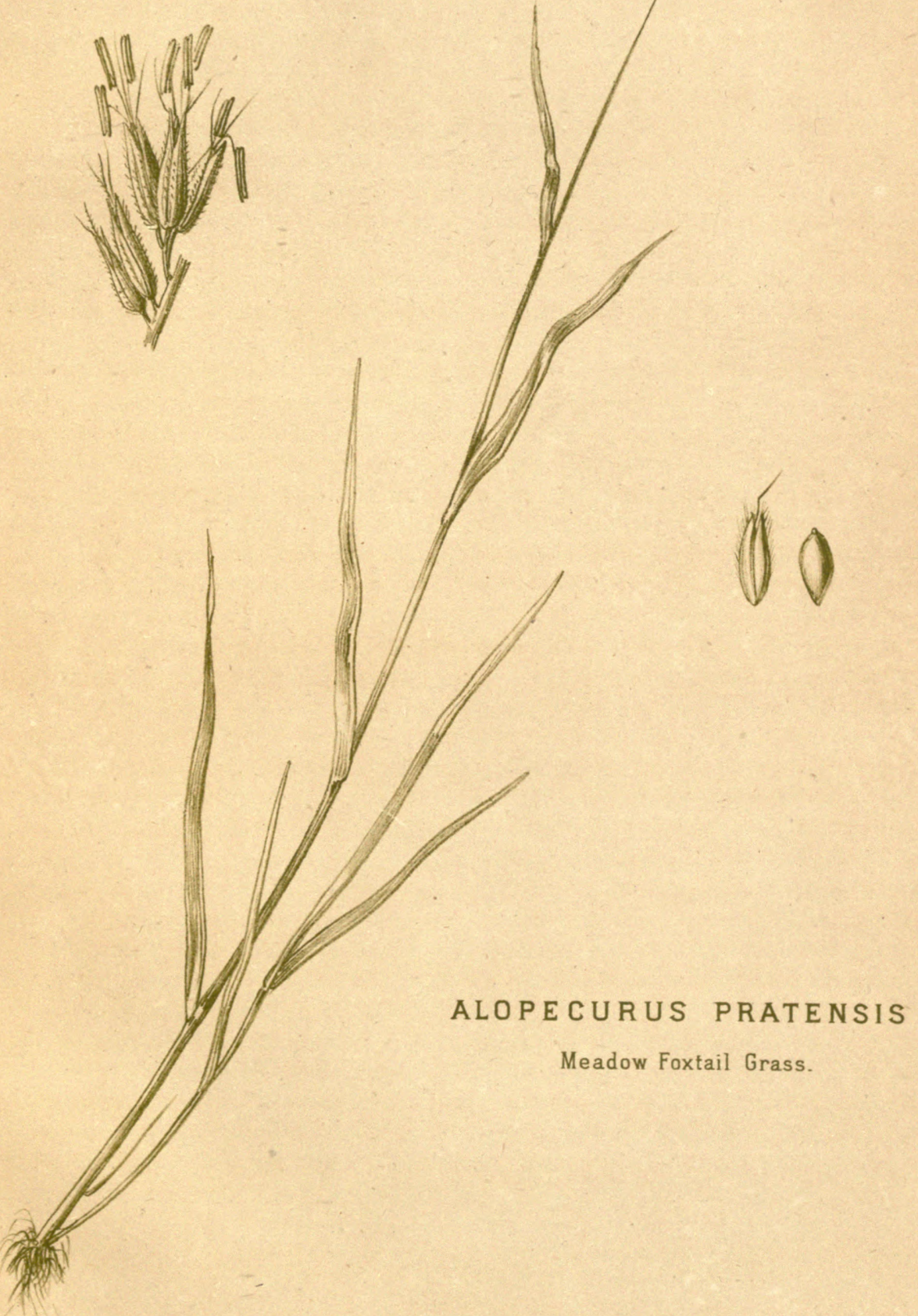



bushels per acre having been produced." At what period it may have been first cultivated is not recorded. In the last quarter of the same century, the only other introduction of importance seems to have been the Chiccory or succory* from France, in 1788 , by Arthur Young; for though the further cultivation of the natural grasses was strenuously advocated by many able authors, as Curtis, Lord Kames, Dr Anderson, Martin, and Nodder, in their "Flora Rustica," and Young, as well as by contributors to agricultural periodicals, yet comparatively little attention seems to have been bestowed on testing their actual merits by field culture.

In Scotland, the cultivation of the artificial grasses was much later of being resorted to than in England. The date of the introduction of Red Clover into Scottish husbandry is not ascertained, but is supposed to have been early in the eighteenth century. In a treatise by the Honourable Society for Improving in the Knowledge of Agriculture, " published for the benefit of the farmers of that kingdom," in 1724 , it is stated that "the people of this country have of late years begun to follow the practice of sowing grass seeds," of which the writer enumerates the red clover, Rye-grass, and Hop Clover, or Trefoil; and recommends, with all or any of the above-mentioned grass seeds, "to sow the seeds of good upland or lea hay, particularly the corn grasses, of all kinds; as also the White Clover, and narrow-leaved plantain " or Rib-grass. Thomas, the sixth Earl of Haddington, and Mr Cockburn of Ormiston, are supposed to have been the first who cultivated red clover in East Lothian, and that between 1720 and 1730 ; but even in 1740 the practice had made little advancement. Lord Cathcart, one of the most eminent of the early improvers, is believed to have introduced the practice into the western counties, having, in 1733 , granted $3 \mathrm{r}$ years' leases to his tenants on the baronies of Auchencross and Cathcart, and within the three following years to those in the lands of Craighall, Layland, and parish of Maybole, one of the conditions of which was, that they should be "obliged to sow ten pounds of red clover seed, for an experiment, on half an acre of the first break of their crofting which falls to be grass." Red clover is also reported to have been first sown in Forfarshire in 1755 , by a farmer in the parish of Logiepert, and in Kincardineshire about 1760 ; but in the northern counties it seems to have been little known, even towards the end of that century. In I 730, Sir William Nicolson, Bart., of Glenbervie, Kincardineshire, by sowing seeds collected promiscuously from natural meadow-hay, among the third or fourth successive crops of oats after lea, was the first in the district of Mearns to make an innovation on the old practice of leaving the land, after being cropped out, to renew its herbage without artificial aid. Sainfoin and Lucern having, at an early period, attracted a good deal of attention among English growers, it was not to have been expected that they should be entirely overlooked even in this less favourable climate. Accordingly, we find, in the Select Transactions of the before-named Society, published in I 743, that the Earl of Stair had, for several preceding years, cultivated both, at New Liston, in West Lothian, and the same nobleman is further stated to have "made noble examples, both in Lothian and Galloway, in the practice of turnip, cabbage, and carrot husbandry, by the plough." From about the year 1765 , the sowing of rye-grass, red, white, and yellow clover, with the occasional addition of rib-grass, seems to lave been pretty general in the best cultivated districts of Scotland. In 1773 , the red or Creeping-rooted $\dagger$ and Sheep's Fescue grasses were grown by Dr Anderson; and about the same period, or shortly after, the then proprietor of Glammis Castle, in Forfarshire, with the view of improving the pasturage about that ancient residence, had the

$$
\text { * Cichorium Intybus } \quad+\text { Festuca rubra }
$$


parks sown down to permanent grass, with seeds saved promiscuously from hay grown in some of the richest meadows in Yorkshire, and to this day the beneficial effects of the experiment are still evident; and no less striking to the botanist than to the grazier, from the prevalence of Avena flavescens, and other grasses, rarely met with in the surrounding country. Towards the end of the century, the fescues, timothy, cocksfoot, Yorkshire fog, and several others of the permanent natural grasses, began to receive some degree of attention, arising, no doubt, from the favourably reported results attendant on their culture in various parts of England, and the persevering advocacy of their merits, both by agricultural and botanical writers.

In Ireland, none of the grasses seem to have been cultivated till after the middle of the eighteenth century. Mr John Wynn Baker, of Lauchlen's Town, near Lexlip, grew the Red Clover about the year 1760 , lucern in 1763 , burnet in $176_{5}$; and in $176_{4}$ he tried an apparently successful experiment with what he called the strawberry clover, which he discovered growing naturally among limestone gravel in the county of Meath,which, however, from the description he gives, cannot have been the Trifolium fragiferum, but more likely the other native Strawberry-headed Clover, $T$. resupinatnm. From the earlier reports on Irish counties, drawn up by order of the Dublin Society, between the years $\mathrm{I} 801$ and I808, it appears that, in the county of Cork, red clover was almost wholly unknown in 1795 , and five years afterwards rye-grass was still unclilivated. In $\mathrm{r} 800$, red clover was cultivated only by the more intelligent agriculturists in the county of Dublin, and rye-grass was even more sparingly grown. About the same date, red and white clover were crops not cultivated to any extent in Armagh, while rye-grass was totally excluded; Timothy-grass was grown by way of experiment near Castle Dobbs in Antrim; and in the county of Down, the reporter mentions that the Cultivated Grasses consisted of red, white, and yellow clover, with rye-grass, white-grass, or Yorkshire fog, and a mixture of hay-seeds from the stable-lofts in towns, containing a large proportion of soft brome or goose-grass. * In ISo I, Mr Wynne of Hazelwood introduced the culture of Lucern into the county of Sligo; and in that and the succeeding.year, Sir Richard St George introduced the cultivation of Lucern, Sainfoin, and Chiccory, into Kilkenny; but the Usual Crops of that country then consisted of red clover, rye-grass, and white grass, with Soft Brome-grass, for the hay of which the English dragoon regiments quartered in Ireland are stated to have given Ios. per ton more than for any other. It appears, however, to have been generally grown in mixture with rye-grass; and, in the earlier stages of grass husbandry, its culture does not seem to have been limited to Ireland alone, as Withering, in his "British Flora," states that he had seen it in some parts sown among clover; while Curtis and Martyn, both eminent botanical writers, recommend it as being very early, and that "its large seeds make the hay more nutritious." To that early practice of sowing the soft brome-grass, may be traced its present appearance in rye-grass fields, where it is now considered an intrusive weed, indicative of impurity in the rye-grass seed; though, like the wild-oat $\uparrow$ and other indigenous annuals, its presence may at least occasionally be traced to the seeds of former crops retaining their vitality when buried to a certain depth in the soil.

Since the commencement of the present century, the increased facilities of communication and conveyance have removed the obstacles which formerly limited, for a considerable period at least, the adoption of any new practice or mode of culture to the district in which it might have originated; so that improvements in England, Scotland, and 


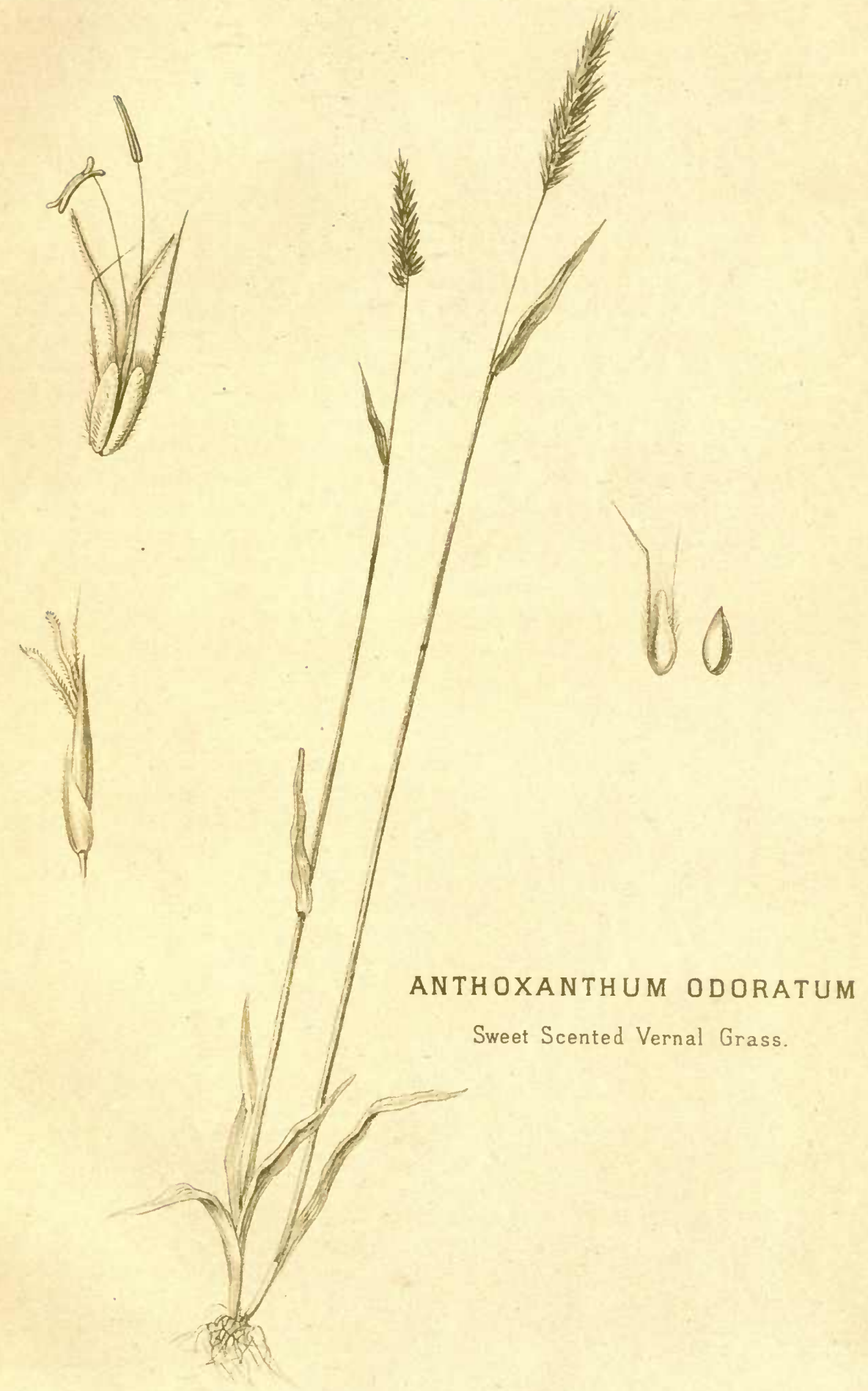



Ireland may now be said to go on simultaneously; and therefore, as further separate notices of the introduction of plants to these countries would merely be a repetition of dates, the most deserving additions which have been made within the past fifty years are recorded in their order of priority, without regard to the different countries in which they were first cultivated.

The Hard Fescue* and Smoothed-stalked Meadow-grasses, + if not cultivated before the end of the eighteenth century, appear at least to have had a little attention bestowed upon then very early in the present, although the exact period, or by whom, has not been ascertained. In 1807 , Dr Richardson, of Portrush, Ireland, created a considerable sensation among agriculturists, by the introduction of his famous Fiorin $¥$ grass, which, as stated at page 4, was cultivated more than forty years before by Stillingfleet, who, in succeeding works of his, endeavoured to impress upon growers the advantage of cultivating it along with the "float fescue, on moist meadow lands," seemingly, however, with very little effect; so that to Dr Richardson belongs the merit of first acquiring for the fiorin a fair and general trial. About 1820 , an extensive set of experiments with grasses, including many exotic as well as native sorts not previously cultivated, was instituted at Woburn Abbey, under the direction of the late Duke of Bedford, the results of which are recorded by the late Mr George Sinclair, then gardener to his Grace, in his invaluable "Hortus Gramineus Woburnensis," which work may justly be said to have first directed that general attention to the cultivation of useful grasses, so long and unaccountably withheld.

In I82I, the Crimson Clover\$ was brought into notice by the late Sir John Sinclair, Bart., and grown in Berwickshire that same year; three years afterwards it was introduced to England, on a much more extended scale, by Mr John Ellman, jun., of Southover, near Leeds. Mr Elles, of Longleat, in I 826, recommended, from experience, the cultivation of the Day-lily, $\|$ as a grateful and early spring food for milk cows. And in I $830, \mathrm{Mr}$ Grant, nurseryman at Lewisham, advertised the rough and Prickly Comfrey, If which he had discovered to be an agreeable, fast-growing, and nutritious food for both cattle and horses. In I831, we first introduced the Italian Rye-grass, ** from Hamburg, and that same year Mr Thomson of Banchory also brought home a few seeds of it from Munich. The late George Stephens, land-drainer, Edinburgh, introduced the Alsike Clover tt from Sweden in 1834 , and in $1835, \mathrm{Mr}$ Smith, at Ayr, brought the Siberian Cow-parsnip $¥ \ddagger$ under the notice of the Highland and Agricultural Soçiety of Scotland, as a productive and early spring food for cattle. The Blackish-headed Fox-tail-grass $\$ S$ was first recommended in 1839 , by a writer in Loudon's "Gardener's Magazine ;" and in I 840 , the Wood-millet, || || or pheasant-grass, was introduced to cultivation.

In I843, the Tussack-grass ๆ 9 of the Falkland Islands attracted considerable attention. This gigantic product of these ungenial regions was especially recommended for trial on the northern and western coasts and islands of Scotland and Ireland. It was observed in 1842 growing luxuriantly on peaty, seaward exposures, by the botanist to the Antartic Expedition, Dr J. D. Hooker (now Director of the Royal Botanic Gardens at Kew), to whom is due the merit of its introduction to Europe.

In I848, we procured from Mr Cunningham, Comely Bank, some plants of the Pampas

* Festuca duriuscula

\$ Trifolium incarnatum

*" Lolium italicum

$\S \S$ Alopecurus nigricans
+ Poa pratensis

II Hemerocallis fulva

+t Trifolium hybridum

|| || Milium effusum
¥ Agrostis alba latifolia

II Symphytum asperrimum

++ Heracleum sibiricum

Iๆ Dactylis cæspitosa 
grass, * described by Humboldt in the "Nova Genera et Species Plantarum." It is a strong coarse grass, growing in large tufts or tussocks, with leaves from eight to ten feet in length. As a feeding plant it is of no value, but it might be profitably employed as a fixer of loose sand-banks, or on the margins of rivers; while its quick growth and hardy nature point it out as an excellent cover for game, and it is now one of our best recognised Ornamental grasses.

Numerous additional species of grasses and other herbage plants have been brought into cultivation within the last thirty or forty years, which are not included in the preceding enumeration, from the dates not having been ascertained. Of these may be mentioned wood meadow-grass, $\uparrow$ nerved-seeded meadow-grass, $₫$ various leaved $\S$ and darnelspiked \| fescue-grasses, float-fescue or floating sweet-grass, $₫$ hill-mustard,** Moliner's clover, + + \&c.

The repeated saving of rye-grass seeds from first crops by the earlier growers resulted, towards the end of the last century, in the prevalence of a short-lived variety, afterwards termed Annual Rye-grass, and unfit, in many cases, for the laying down of land to two or more years' pasture; which naturally directed attention to the selection of a more lasting variety. Accordingly, we find that this desideratum was then supplied by Mr Pacey, of North Leach, Wiltshire, whose Perennial Rye-grass, as it is still called, soon became known throughout both Scotland and England. Mr Pacey's example was followed by many other cultivators, each of whom discovered, or fancied he had discovered, a variety possessing new or additional merits, so that, prior to the publication of the "Hortus Gramineus Woburnensis" in 1824 , Dickson's, Ruck's, Russel's, Stickney's, Whitworth's, \&c., had been introduced. Since that period, names of other particular growers have been added to the list; so that it now requires no little discrimination to fix on what are really the most deserving of cultivation. About I830, Mr. T. Bishop, at Methven Castle, Perthshire, brought out an Evergreen Variety of the wood meadow-grass.++ In 1833, we introduced from France the Double Yielding Sainfoin, S§ a very luxuriant growing variety. The Tree Clover from Bokhara, || || a tall variety of white melilot, which attains a height of from ro to 16 feet, created a little sensation in 1839 , when first brought to this country. In the following year, a very early, but rather dwarf-growing, variety of Lucern from Affghanistan, $१$ ๆ was received through the East India Company; and in $184 \mathrm{r}$, we introduced from Hamburg two strong growing grasses, the one a variety of Cocksfoot, ${ }^{*}{ }^{*}$ and the other of the Wood Meadowgrass, $\nmid \dagger \dagger$ both, however, not now, in commerce. In the same year, we received from the Botanic Gardens of Berlin seeds of a very succulent and rapid-growing grass, under the name of Bromus Schraderi, which, on first trial, seemed to be possessed of highly important qualities, but was found too tender for the severe winter of I844-45. In I 844, the Bulbous Barley-grass +++ was noticed in the "Bon Jardinier" as being naturally well adapted for chalky and other dry calcareous soils, and has since been found to succeed on such in the south of England; for which localities the Villous Wheat-grass ss was also recommended about the same time; but being of diminutive growth, and only of biennial duration, its culture has not been attended with equal success.

\footnotetext{
* Gynerium argenteum

§ Festuca heterophylla

** Bunias orientalis

$\S \S$ Onobrychis sativa bifera

* * Dactylis glomerata gigantea
}

\author{
+ Poa nemoralis \\ II Festuca loliacea \\ + Trifolium Molineri \\ II II Melilotus leucantha major \\ t+ $\mathrm{Poa}$ nemoralis gigantea
}

§s§ Triticum villosum
+ Poa nervata

T Poa aquatica

+¥ Poa nemoralis sempervirens

ๆT Medicago sativa pracox +++ Hordeum bulbosum 


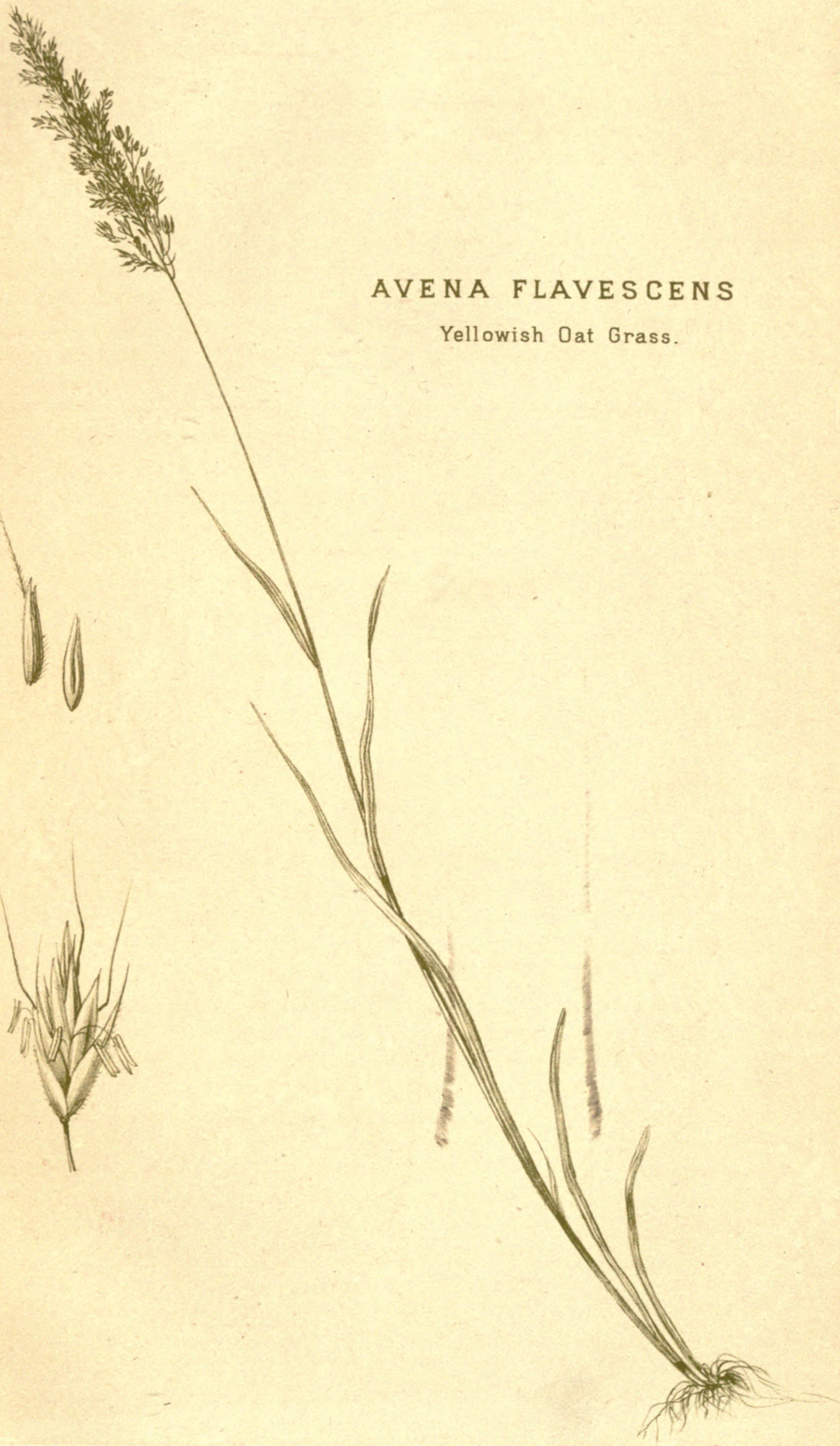



So far as regards the indigenous grasses, it does not appear that much improvement remains to be further effected by the introduction of species, although important results may be anticipated from extending the field-culture of many of those which may be said to have hitherto only formed subjects of experiment. As, however, the cultivation of original species constitutes only the first steps in the improvement of plants, it is therefore to the selection of permanent varieties of these, distinguished from their origins by the possession of superior qualities, as greater growth, earlier maturity, adaptation to particular purposes, \&c., that we are ultimately to look for the most beneficial results. It must be kept in mind, however, that, although much remains to be done in this department, yet enough has been accomplished, to point out the derivable advantages, and thereby stimulate cultivators to further exertions. 


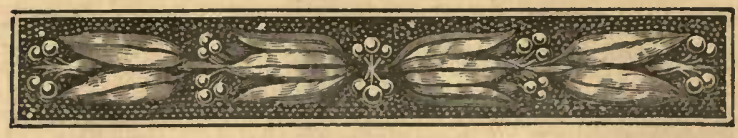

\section{CHAPTER II.}

\section{WHICH ENUMERATES THE KINDS AND SPECIFIES THE QUANTITY OF SEEDS FOR SOWING THE IMPERIAL ACRE.}

$T^{1}$

$\mathrm{HE}$ extraordinary and unaccountable disparity in the quantity and proportion of grass seeds sown by different individuals, has often been noticed, as involving a question of considerable pecuniary importance, some of the earlier authors having recommended as much as $20 \mathrm{lbs}$. of each of the red, white, and yellow clovers, with half that weight of rib-grass, and 3 bushels of rye-grass per acre ; while others asserted that onefourth of that quantity was sufficient. Nor do present cultivators, in many instances, approach much nearer to a unanimity of practice. This being the case in regard to the commoner grasses and clovers, a still greater uncertainty, as was to be expected, prevailed respecting the proper quantities and proportions of the comparatively recently introduced sorts. These circumstances induced us, in 1834 , to lay before the public, throingh the medium of the "Quarterly Journal of Agriculture," a communication on the kinds and quantities of grass seeds suited to alternate husbandry, permanent pasture, pleasure grounds, \&c., a revised copy of which we again published in our "Agriculturist's Manual" in 1836 . As several sorts can now be had at reasonable rates, which were then little known, or so scarce and high-priced that their introduction, in proper quantities, would have unwarrantably heightened the price per acre for seeds, we have deemed it proper, at this time, again to submit to the attention of cultivators, the following further improved series of tables, which will be found to combine the results of carefully conducted experiments, extending over a period of more than fifty years, with the latest introductions and improvements in practice.

It was formerly the practice to sow the grasses by measure, and the clovers by weight; but of late, the more judicious innovation of sowing the whole by weight is now the universal system; for although the greater weight in one sort is no criterion of its superiority over less weight in another, yet a greater weight in the same kind always denotes a superior quality. Thus, when seed is light and consequently inferior, the greatest number of seeds is obtained by adhering to a given weight; and hence there is a chance of nearly an equal number of plants springing up as when the seeds are plump and heavy. But a given weight or measure, applied to the seeds of different grasses, is no indication of the number of plants each sort will produce-there being material differences both in the relative bulk and specific gravities of such seeds, as well as a difference in the number of each which germinate in a given quantity. In making out the tables, these variations have, therefore, been carefully studied.

It must, however, be kept in view, that, even under the most careful management, a greater proportion of the plants produced by the smaller seeds perish at, or immediately 
after, the period of brairding, than of the more robust produce of the larger seeds; while a considerable number of the former become entirely lost in consequence of an overdeptl of covering. As an exemplification of this, we subjoin the following table, by J. D. Stirling, Esq., of Glenbervie, in Vol. XV. of the "Transactions of the Highland and Agricultural Society of Scotland," on the results of experiments to prove the best depth of cover for certain grasses and clovers.

In all cases the seeds enumerated in the following Table were sown on the rst of July and counted early in the following month.

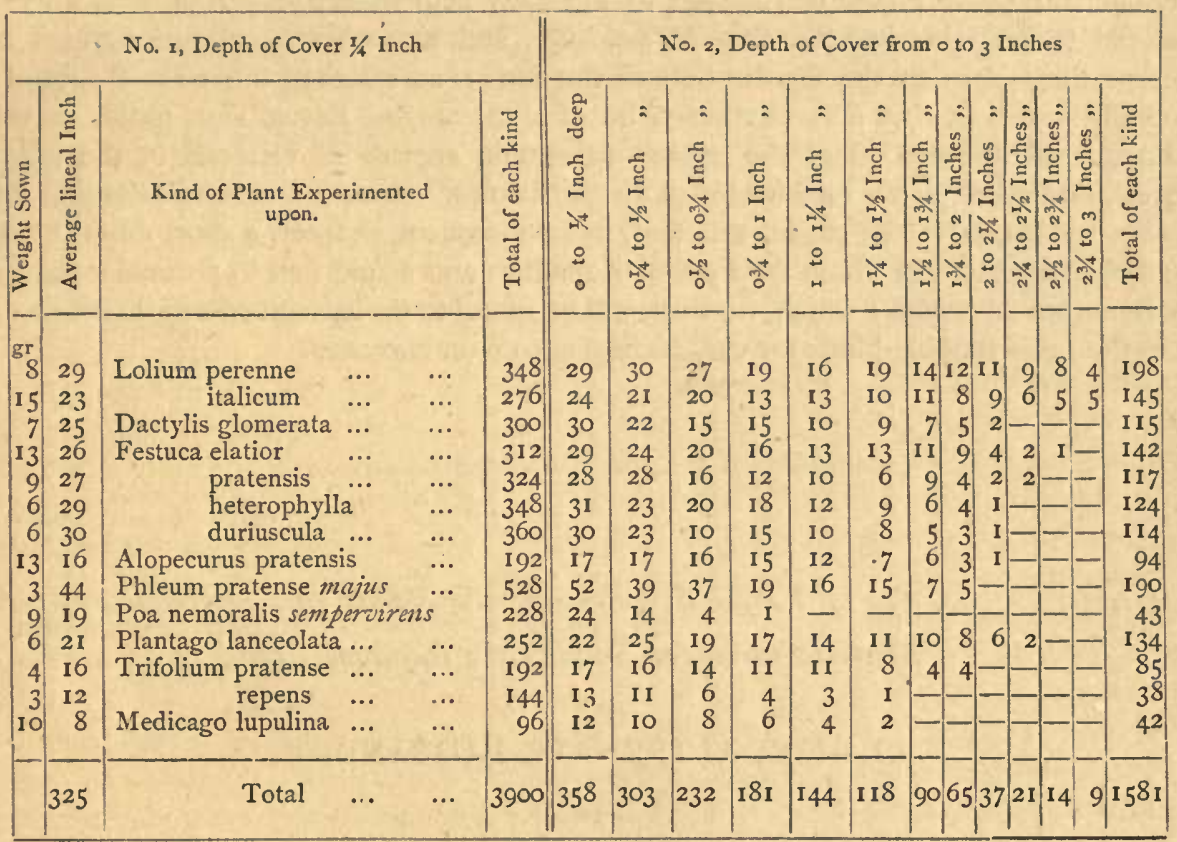

The above results were arrived at by sowing the seeds in finely sifted dark loam, which was kept moist during the whole period of germination. To these circumstances, the fact of so many seeds brairding without cover is no doubt attributable ; but as in ordinary field sowing such a combination of favourable circumstances, as to soil and moisture, cannot be looked for, a slight covering of earth is always desirable.

It is not our purpose here to discuss the question, as to whether it is better to sow grass seeds for permanent pasture with or without a corn crop. Both systems have their advocates, as well as their advantages and defects, and depend, in a great measure, on the varied circumstances which present themselves in practice. Therefore, in the following Tables, separate columns are given for each of these methods; it being always expedient to sow a somewhat larger portion of seeds without, than with, a corn crop; and in that case, it is further advisable, for affording shelter to the young plants, to add a bushel of rye to the mixture, when sown in autumn, and a bushel of barley, when sown in springto be depastured or cut green along with the young grass crop. 
To give a series of Tables comprehending all the variations of soils, altitudes, climates, and other circumstances which may present themselves in course of practice, would be inexpedient, and almost impossible; but the following will be found to embrace the different purposes for which lands are generally sown down with grasses, as well as the most distinct classes of soils under culture. Judgment and discrimination must, however, in many instances be exercised, both in regard to the kinds and quantities of seeds to be sown. Thus, it may be expedient, in particular cases, to withdraw, wholly or partly, certain kinds, and to substitute others, especially where lands are known naturally to produce any particular sort, which, although desirable to a certain extent, may, when too predominant, prove rather detrimental to the crop than otherwise. And it is also very material to keep in view the altitude, exposure, and any other peculiarities which may present themselves in the constitution of the land: as whether the soil or subsoil be naturally moist or dry, and whether it be of a calcareous, ferruginous, peaty, or other nature, at all likely to affect the growth of certain species or varieties of the grasses, clovers, and other plants recommended in the Tables. With the view of affording information on this point, the reader will find, in a subsequent chapter, a short description of the different grasses, in which their peculiar qualities and adaptation to particular soils and situations are described ; which, we trust, will be useful to the agriculturist in discriminating as to the most suitable kinds for use, according to circumstances.

I Here follow a Series of TABLES, showing the Kinds and Quantities of Grass Seeds required for Sowing the Imperial Acre.

\section{I.-FOR ALTERNATE HUSBANDRY}

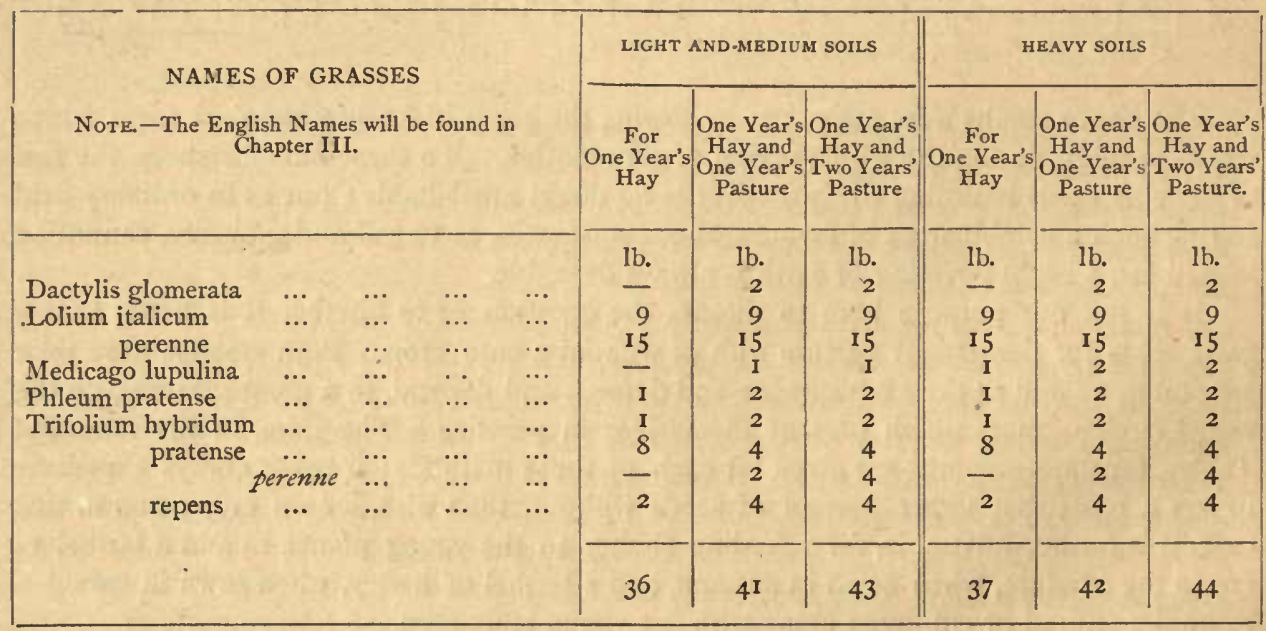


In sheep pastures it will be advisable to sow, in addition, I lb. per acre of Fetroselinum satizum, and in upland districts from $2 \mathrm{lb}$. to $3 \mathrm{lb}$. per acre of Plantago lanceolata, and from $\times \mathrm{lb}$. to $2 \mathrm{lb}$. of Medicago lupulina. In proportion to the retentiveness of very heavy soils, as well as those of a peaty nature, Phleum pratense should also be increased, at the rate of $x \mathrm{lb}$. to $\mathrm{I} \frac{1}{2} \mathrm{lb}$. per acre.

II.-FOR PERMANENT PASTURE.-NO. I.

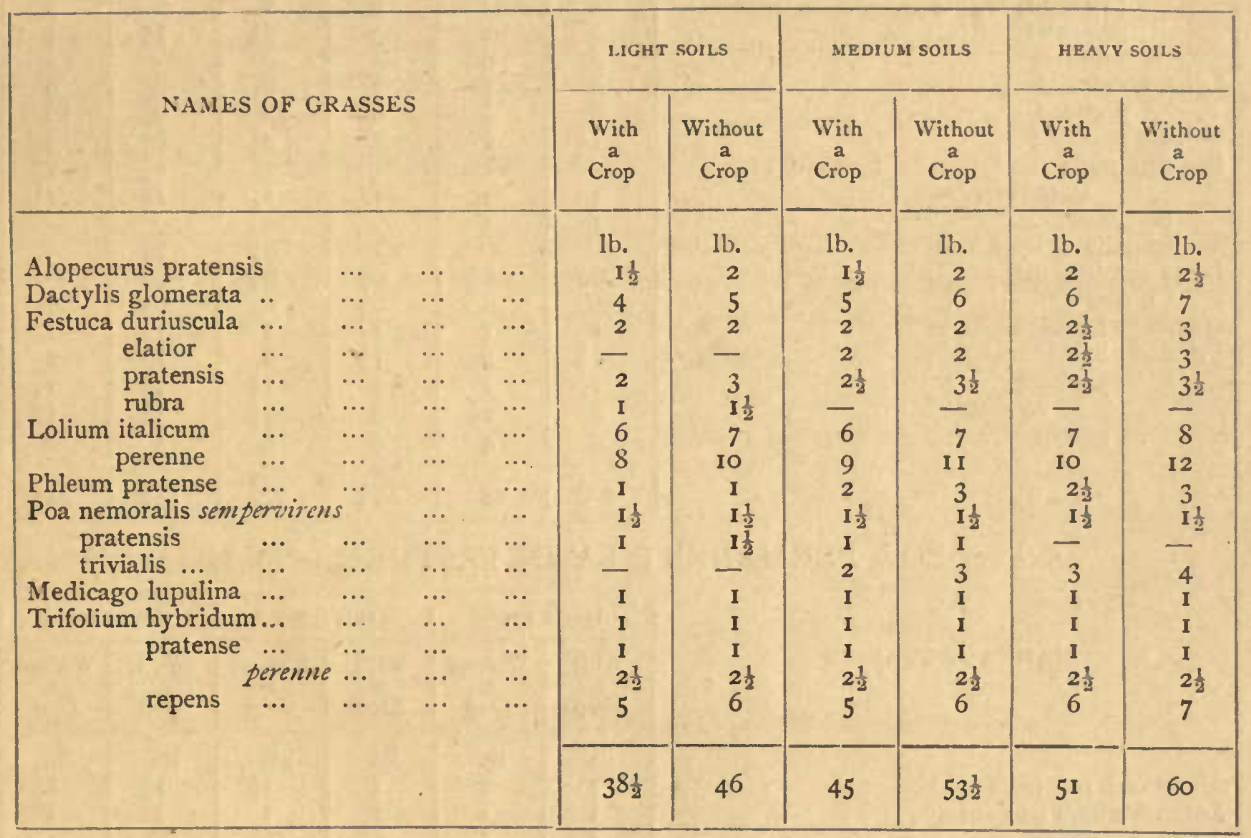

The above Table is drawn out with a view to the strictest economy in the original outlay. The one following will be found to contain a greater proportion of the more valuable kinds of grasses; and although these will add to the first expense, yet the improvement in the produce will generally much more than compensate for the additional primary cost.

In certain cases, the following additions to Tables II. and III. may be made, viz. : $\frac{1}{2} \mathrm{lb}$. to I lb. Achillea Millefolium, in dry sheep pastures; $6 \mathrm{lb}$. to ro lb. Onobrychis sativa, and $4 \mathrm{lb}$. to $6 \mathrm{lb}$. Poterium Sanguisorba, on dry calcareous soils; I lb. to $2 \mathrm{lb}$. Petroselinum sativum, in lands where sheep are subject to the rot; $\mathrm{x} 1 \mathrm{lb}$. to $2 \mathrm{lb}$. each Festuca rubra and Poa pratensis on dry sandy soils. When a crop of hay is taken the first year, both the rye-grasses may be increased one-third, and $2 \mathrm{lb}$. Trifolium pratense and I $1 \mathrm{~b}$. Trifolium hybridum added. Where occasional crops of hay are to be taken, $\frac{1}{2} \mathrm{lb}$. per acre of Anthoxanthum odoratum should be added to Table II. 
III.-FOR PERMANENT PASTURE-No. 2.

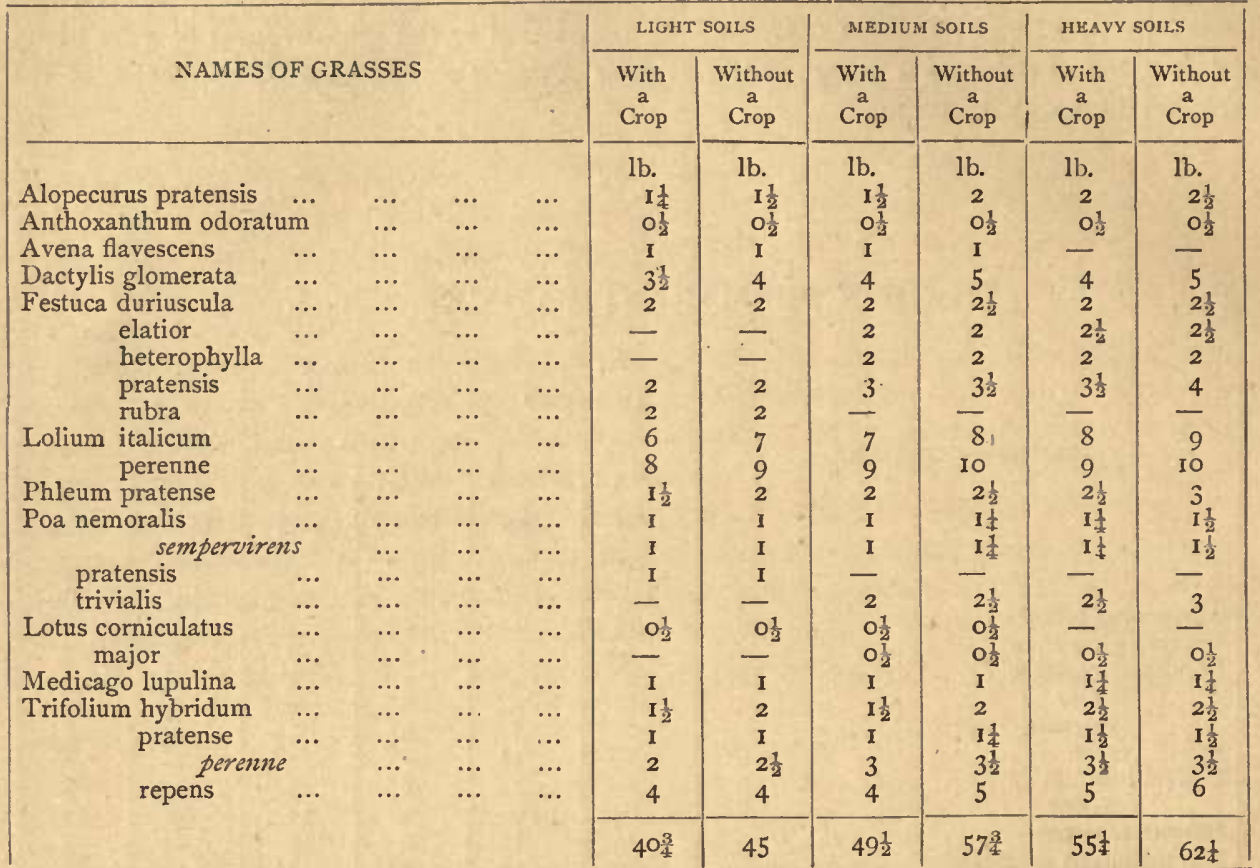

IV.-FOR PERMANENT LAWN PASTURE.-No. I.

\begin{tabular}{|c|c|c|c|c|c|c|c|c|c|c|}
\hline & & & & & LIGI & soils & MED & solls & HEA & sorls \\
\hline NAMES O & F GF & SSES & & & With & Without & With & Without & With & Without \\
\hline $\mathrm{v}$ & & & & & Crop & Crop & Crop & Crop & Crop & \\
\hline & & & & & lb. & lb. & lb. & lb. & lb. & lb. \\
\hline Alopecurus pratensis & ... & $\ldots$ & & $\ldots$ & I & $\mathrm{I}$ & I & $\mathrm{I} \frac{1}{4}$ & $\mathrm{I} \frac{1}{4}$ & I $\frac{1}{2}$ \\
\hline Anthoxanthum odoratur & & & & & I & I & I & I & $I^{2}$ & I \\
\hline Avena flavescens & $\ldots$ & $\ldots$ & $\ldots$ & $\ldots$ & I & I & $\mathrm{O}_{4}^{3}$ & $0 \frac{3}{4}$ & - & - \\
\hline Dactylis glomerata & $\ldots$ & $\ldots$ & $\ldots$ & $\ldots$ & 3 & 4 & 3 & 4 & 3 & 4 \\
\hline Festuca duriuscula & $\ldots$ & $\ldots$ & $\ldots$ & $\ldots$ & 3 & 3 & 3 & 4 & 3 & 4 \\
\hline ovina & $\ldots$ & $\ldots$ & $\ldots$ & $\ldots$ & I & I & I & I & I & $\mathrm{I}$ \\
\hline pratensis & $\ldots$ & $\ldots$ & $\ldots$ & $\cdots$ & $2 \frac{1}{3}$ & 3 & 3 & $3 \frac{1}{2}$ & $3 \frac{1}{2}$ & $3 \frac{1}{2}$ \\
\hline rubra & $\ldots$ & $\ldots$ & $\ldots$ & $\ldots$ & I & I & & $\bar{n}$ & - & 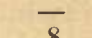 \\
\hline Lolium italicum & $\ldots$ & $\ldots$ & $\ldots$ & $\ldots$ & 5 & 6 & 6 & 7 & 7 & 8 \\
\hline perenne & $\ldots$ & $\ldots$ & .. & $\ldots$ & 7 & 8 & 8 & 9 & 9 & 10 \\
\hline Phleum pratense & $\ldots$ & $\ldots$ & ... & $\ldots$ & i。 & I & I & I $\frac{2}{3}$ & $I_{\frac{1}{2}}$ & 2 \\
\hline Poa nemoralis $\ldots$. & $\ldots$ & $\ldots$ & $\ldots$ & $\ldots$ & $\mathrm{O}_{4}^{8}$ & I & I & I $\frac{1}{4}$ & $1 \frac{3}{4}$ & I $\frac{1}{4}$ \\
\hline semperviren & & $\ldots$ & $\ldots$ & $\ldots$ & $0_{4}^{3}$ & I & I & I & I $\frac{1}{4}$ & $1 \frac{7}{4}$ \\
\hline trivialis & 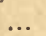 & $\ldots$ & $\ldots$ & $\ldots$ & - & - & 2 & 3 & 2 & 3 \\
\hline Lotus corniculatus & $\ldots$ & $\ldots$ & $\ldots$ & $\ldots$ & of & 01 & of & $0 \frac{1}{4}$ & - & - \\
\hline major $\quad \ldots$ & $\ldots$ & $\ldots$ & ... & $\ldots$ & 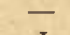 & - & $0 \frac{1}{4}$ & $0 \frac{1}{4}$ & $0 \frac{1}{4}$ & of \\
\hline Medicago lupulina & $\ldots$ & $\ldots$ & $\ldots$ & $\ldots$ & I & I & I & I & I & \\
\hline Trifolium hybridum & $\ldots$ & $\ldots$ & $\ldots$ & $\ldots$ & I & I & I & I $\frac{1}{x}$ & $\mathbf{1} \frac{1}{4}$ & $1 \frac{1}{2}$ \\
\hline pratense & $\ldots$ & & $\ldots$ & $\ldots$ & 2 & 2 & 2 & 2 & 2 & 2 \\
\hline perenne & & $\ldots$ & $\ldots$ & $\ldots$ & 2 & 2 & 2 & 2. & 2 & 2 \\
\hline repens & ... & $\ldots$ & ... & $\ldots$ & 4 & 5 & 5 & 5 & 5 & 5 \\
\hline & & & & . & $38 \frac{1}{4}$ & 431 & $43 \frac{1}{4}$ & $50 \frac{1}{1}$ & $46 \frac{1}{1}$ & 521 \\
\hline
\end{tabular}


The remarks concerning Tables II. and III. are also applicable to Tables IV. and V., except that Onobrychis sativa should be lessened by at least one-half, its foliage being coarse and unsightly. On warm dry banks, cowslip seed (Primula veris) may be scattered at the rate of from $\frac{1}{4} \mathrm{lb}$. to $\frac{1}{2} \mathrm{lb}$. per acre; and on such parts as are overshadowed. by trees, a further quantity of Poa nemoralis, and its variety, sempervirens, should be added, at the rate of from $2 \mathrm{lb}$. to $4 \mathrm{lb}$. per acre; while on very dry banks the introduction of from I lb. to $2 \mathrm{lb}$. each of Agrostis vulgaris, Poa pratensis, and the deeper rooting varieties of Festuca duriuscula, or $F$. rubra, would prove a guarantee against the destruction of the pasture by severe droughts.

\section{V.-FOR PERMANENT LAWN PASTURE-No. 2.}

\begin{tabular}{|c|c|c|c|c|c|c|c|c|c|c|}
\hline & & & & & LIGH & soins & MELT & is soils & HEA & solis \\
\hline NAMES C & OF & RASSE & & & $\begin{array}{c}\text { With } \\
\text { a } \\
\text { Crop }\end{array}$ & $\begin{array}{c}\text { Without } \\
\text { a } \\
\text { Crop }\end{array}$ & $\begin{array}{l}\text { With } \\
\text { a } \\
\text { Crop }\end{array}$ & $\begin{array}{c}\text { Without } \\
\text { a } \\
\text { 'Crop }\end{array}$ & $\begin{array}{l}\text { With } \\
\text { a } \\
\text { Crop }\end{array}$ & $\begin{array}{c}\text { Without } \\
\text { a } \\
\text { Crop }\end{array}$ \\
\hline & & & & & lb. & lb. & lb. & lb. & lb. & lb. \\
\hline $\begin{array}{l}\text { Alopecurus pratensis } \\
\text { Anthoxanthum odoratu }\end{array}$ & & $\cdots$ & $\cdots$ & $\cdots$ & I & I & I & $1 \frac{1}{4}$ & I $\frac{1}{4}$ & $1_{\frac{1}{2}}^{\frac{1}{2}}$ \\
\hline Avena flavescens & $\ldots$ & $\ldots$ & $\ldots$ & $\ldots$ & I & I & $\mathrm{I} \frac{1}{2}$ & I 1 & - & 1 \\
\hline Dactylis glomerata & $\ldots$ & $\ldots$ & $\ldots$ & $\ldots$ & 2 & $2 \frac{1}{4}$ & 2 & $2 \frac{1}{4}$ & 2 & $2 \frac{1}{2}$ \\
\hline Festuca duriuscula & $\ldots$ & $\ldots$ & $\ldots$ & $\ldots$ & $2 \frac{8}{4}$ & 3 & 3 & 3 & $3 \frac{1}{2}$ & 4 \\
\hline heterophylla & $\ldots$ & $\ldots$ & $\ldots$ & $\ldots$ & - & - & I & I & I & I \\
\hline ovina $\ldots$ & $\ldots$ & $\ldots$ & $\ldots$ & $\ldots$ & I & I & I & I & $1 \frac{1}{4}$ & $\mathbf{I} \frac{1}{4}$ \\
\hline pratensis & $\ldots$ & $\ldots$ & $\ldots$ & $\cdots$ & 2 & 3 & 3 & $3 \frac{1}{2}$ & $3 \frac{1}{2}$ & 4 \\
\hline rubra & $\ldots$ & .. & $\ldots$ & $\ldots$ & I & I & 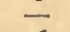 & & & \\
\hline Lolium italicum & $\ldots$ & $\ldots$ & $\ldots$ & $\ldots$ & 5 & 6 & 6 & 7 & 7 & 8 \\
\hline perenne & $\ldots$ & .. & $\ldots$ & $\ldots$ & 6 & 7 & 7 & 8 & 8 & 9 \\
\hline Phleum pratense & $\ldots$ & $\ldots$ & $\ldots$ & $\ldots$ & I & I & I & $1 \frac{1}{4}$ & I $\frac{1}{2}$ & 2 \\
\hline Poa nemoralis $\ldots$ & $\ldots$ & $\ldots$ & $\ldots$ & $\ldots$ & I & I & I & 1告 & I & $I_{2}^{\frac{1}{2}}$ \\
\hline sempervirens & $\ldots$ & $\ldots$ & $\ldots$ & $\ldots$ & 2 & 2 & 2 & 2 & 2) & $2 \frac{1}{3}$ \\
\hline trivialis $\quad \ldots$ & $\ldots$ & $\ldots$ & $\ldots$ & $\ldots$ & $I_{\frac{1}{2}}$ & 2 & 2 & $2 \$$ & $2 \frac{1}{2}$ & 3 \\
\hline Lotus corniculatus & $\ldots$ & $\ldots$ & $\ldots$ & $\ldots$ & $0 \frac{1}{2}$ & $0 \frac{1}{2}$ & $0 \frac{1}{4}$ & $0 \frac{1}{4}$ & - & 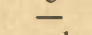 \\
\hline major & $\ldots$ & $\ldots$ & $\ldots$ & $\ldots$ & - & - & of & of & O $\frac{1}{2}$ & $0 \frac{1}{2}$ \\
\hline Medicago lupulina & ... & $\ldots$ & $\ldots$ & $\ldots$ & I & I & I & I & I & 1 \\
\hline Trifolium pratense & $\ldots$ & $\ldots$ & $\ldots$ & $\ldots$ & I & I & I & I & I & I \\
\hline perenne & & $\ldots$ & $\ldots$ & $\ldots$ & 2 & 2 & 2 & 2 & 2 & 2 \\
\hline hybridum & ... & $\ldots$ & $\ldots$ & $\ldots$ & 2 & 2 & 2 & 2 & 2 & 2 \\
\hline repens & .. & $\cdots$ & $\ldots$ & $\ldots$ & 3 & 4 & 3 & 4 & 3 & 4 \\
\hline & & & & & $37 \frac{9}{4}$ & $42 \frac{7}{4}$ & 42 & $46 \frac{8}{4}$ & $45 \frac{1}{2}$ & $51^{\frac{3}{4}}$ \\
\hline
\end{tabular}


VI.-FOR FINE LAWNS, CROQUET GREENS, BOIVLING GREENS, BLEACHING GREENS, \&c.

KEPT CONSTANTLY UNDER THE SCYTHE.

\begin{tabular}{|c|c|c|c|c|c|c|c|c|c|}
\hline \multirow{2}{*}{\multicolumn{4}{|c|}{ NAMES OF GRASSES }} & \multicolumn{2}{|c|}{ LIGHT SOILS } & \multicolumn{2}{|c|}{ MEDIUM SOILS } & \multicolumn{2}{|c|}{ HEAVY SOILS } \\
\hline & & & & $\begin{array}{l}\text { With } \\
\text { a } \\
\text { Crop }\end{array}$ & $\begin{array}{l}\text { Without } \\
\text { a } \\
\text { Crop }\end{array}$ & $\begin{array}{l}\text { With } \\
\text { a } \\
\text { Crop }\end{array}$ & $\begin{array}{l}\text { Without } \\
\text { a } \\
\text { Crop }\end{array}$ & $\begin{array}{l}\text { With } \\
\text { a } \\
\text { Crop }\end{array}$ & $\begin{array}{c}\text { Without } \\
\text { a } \\
\text { Crop }\end{array}$ \\
\hline & & & & lb. & lb. & lb. & lb. & lb. & lb. \\
\hline & $\cdots$ & $\cdots$ & $\cdots$ & $\begin{array}{l}\text { I } \\
8\end{array}$ & $\begin{array}{l}1 \\
8\end{array}$ & I & I & $\overline{T 0}$ & - \\
\hline $\begin{array}{ll}\text { Cynosurus cristatus } & \ldots \\
\text { Festuca duriuscula } & \ldots\end{array}$ & $\ldots$ & $\therefore$ & $\cdots$ & $\begin{array}{l}8 \\
3\end{array}$ & 8 & $\begin{array}{l}9 \\
4\end{array}$ & 9 & Io & IO \\
\hline ovina tenuifolia & $\cdots$ & $\ldots$ & $\cdots$ & $\frac{3}{2}$ & $\frac{3}{2}$ & $\frac{4}{2}$ & $\begin{array}{l}4 \\
2\end{array}$ & I & I \\
\hline Lolium perenne tenue & $\ldots$ & $\ldots$ & $\ldots$ & 18 & 20 & 20 & 22 & 22 & 24 \\
\hline Poa nemoralis & $\ldots$ & $\ldots$ & $\ldots$ & 2 & 2 & 2 & 2 & 2 & 2 \\
\hline sempervirens & $\ldots$ & $\ldots$ & ... & 2 & 2 & 2 & 2 & 2 & 2 \\
\hline trivialis & $\ldots$ & $\ldots$ & ... & I & I & I & I & $I_{2}^{\frac{1}{2}}$ & $I \frac{1}{2}$ \\
\hline Trifolium repens & $\ldots$ & $\ldots$ & $\ldots$ & 6 & 7 & 6 & 7 & 6 & 7 \\
\hline minus & ... & $\ldots$ & $\ldots$ & 2 & 2 & 2 & 2 & I & i \\
\hline & - & & & 45 & $4^{8}$ & 49 & 52 & $50 \frac{1}{2}$ & $53 \frac{1}{2}$ \\
\hline
\end{tabular}

In cases where primary expense is deemed secondary to ultimate effect, $2 \mathrm{lb}$. Poa nemoralis sempervirens may be added to each of the above columns; and where the ground is much shaded by trees, the above quantity of that variety and the same of Poa nemoralis should be substituted for similar quantities of Festuca tenuifolia and Avena flavescens, such quantities being dependent on the extent and depth of the shade.

In walks, bowling greens, \&c., which are wished to be kept as dry as possible, especially towards the end of the season, Trifolium repens should be sparingly introduced, and Cynosurus cristatus and Festuca duriustula substituted for it weight by weight; and when it is intended to mow the grass by machine, instead of the common scythe, greater proportions of Festuca duriuscula and $F$. tenuifolia may be sown.

VII.-FOR LANDS IN PREPARATION FOR IRRIGATION

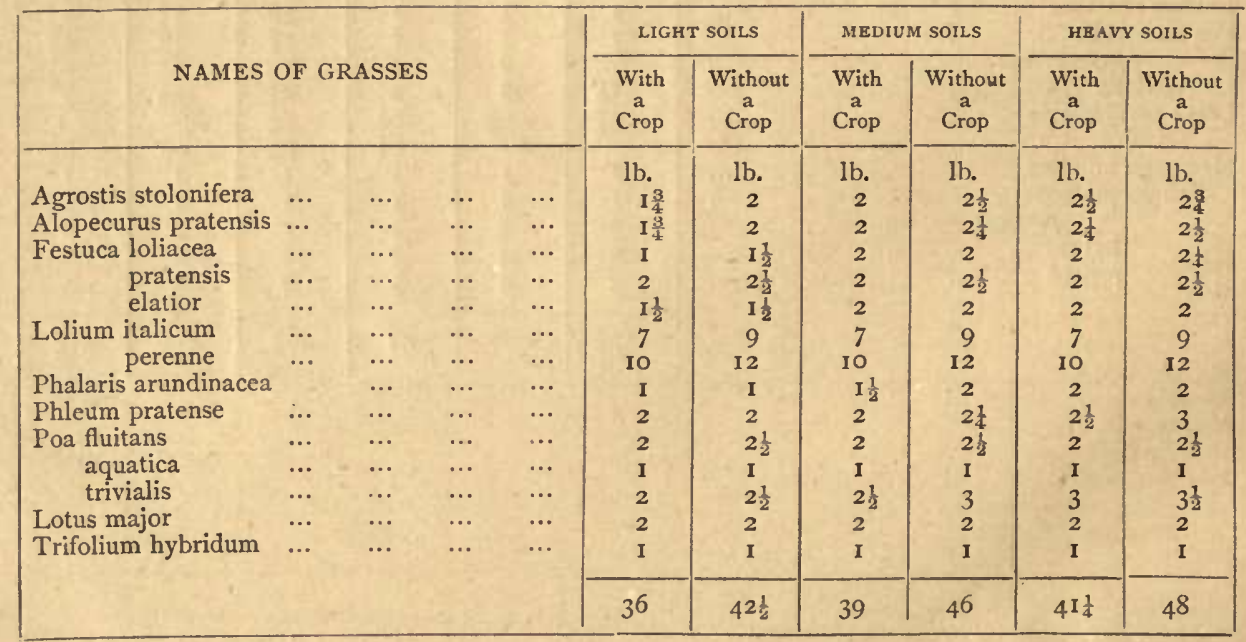


When desirable, the expense of the above mixture may be decreased a few shillings per acre, by excluding the Alopecurus pratensis (which is only recommended in consideration of its earliness), and half of the Lotus major; under most circumstances, however, it will be advisable to retain the full quantity of the latter, not only from its being the best adapted of the clover tribe for withstanding excess of moisture, but also from its attaining to full maturity at a late period of the season, when the growth of the grasses, generally becomes more vigorous.

VIII,-FOR PERMANENT PASTURE AND HAY, IN ORCHARDS AND OTHER GROUNDS MUCH OVERSHADED BY TREES

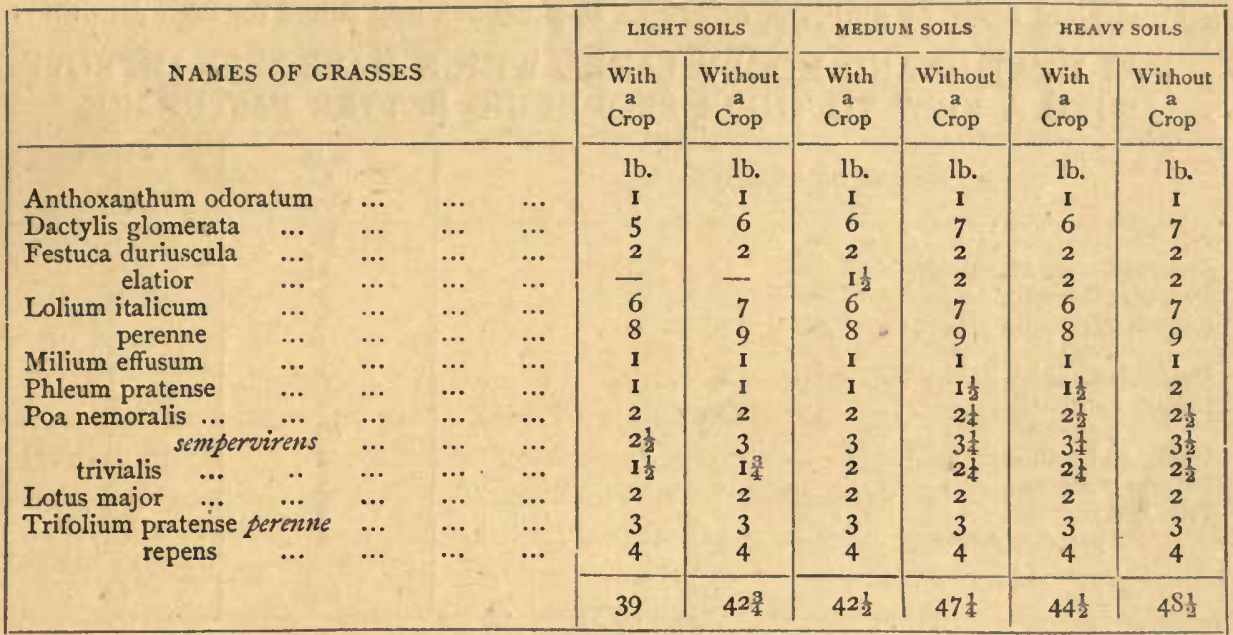

Where the appearance of coarse growing grasses is objectionable, Dactylis glomerata, Festuca elatior, and Phleum pratense, may either be lessened in quantity or entirely excluded, and substituted by an increase of about two-thirds of their weight of Festuca duriuscula, and the three species of Poa.

IX.-FOR PASTURAGE AND COVER IN THICK SHADY WOODS AND PLANTATIONS

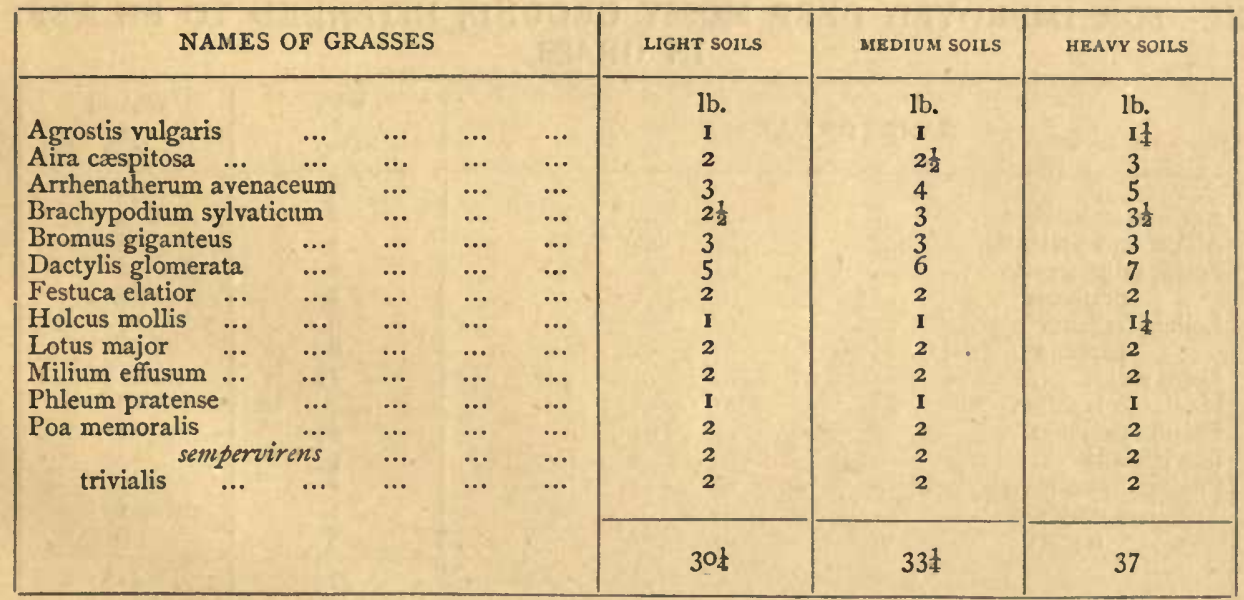


When the chief object to be attained is a coarse grassy game cover, under very thick trees, the quantities of Aira caspitosa, Arrhenatherum avenaceum, Brachypodium sylvaticum, Bromus giganteus, Fiestuca elatior, and Milium effusum, should be increased one half, and a corresponding deduction made in the seeds of Agrostis vulgaris, Poa nemoralis, and its 'variety sempervirens, Poa trivialis, and Lotus major. Where, however, a fine grassy verdure is desired, the quantities of Aira ccespitosa, Arrhenatherum avenacenm, Brachypodium sylvaticum, Bromus giganteus, and Festuca elatior, should be diminished, and the others proportionally increased. With reference to Milium effusum, where it is desirable to introduce it extensively, for feeding game with its seeds, the most successful and economical method, is, first, to rear the young plants in nursery or garden ground, and then transplant them, by dibber or otherwise, to situations best suited for their growth.

X.-FOR HEATHY AND MOORY LANDS, WHICH HAVE BEEN IMPROVED WITH A VIEW TO THEIR PRODUCING BETTER PASTURAGE

\begin{tabular}{|c|c|c|c|c|c|c|c|c|c|}
\hline \multicolumn{8}{|c|}{ NAMES OF GRASSES } & $\begin{array}{l}\text { With } \\
\text { a } \\
\text { Crop }\end{array}$ & $\begin{array}{c}\text { Without } \\
\text { a } \\
\text { Crop }\end{array}$ \\
\hline \multirow{2}{*}{\multicolumn{2}{|c|}{ Arrhenatherum avenaceum }} & & & & & & & lb. & lb. \\
\hline & & ... & ... & $\ldots$ & $\cdots$ & $\cdots$ & $\cdots$ & $2 \frac{1}{2}$ & 3 \\
\hline Dacytlis glomerata & $\ldots$ & $\ldots$ & ... & $\ldots$ & ... & $\ldots$ & $\ldots$ & 3 & 4 \\
\hline \multirow{2}{*}{$\begin{array}{c}\text { Festuca duriuscula } \\
\text { ovina }\end{array}$} & ... & ... & ... & … & ... & ... & $\ldots$ & 2 & $2 \frac{1}{2}$ \\
\hline & $\ldots$ & ... & ... & $\ldots$ & $\ldots$ & ... & $\ldots$ & I & $\mathbf{I}$ \\
\hline Holcus lanatus & ... & $\ldots$ & ... & ... & ... & $\ldots$ & ... & 2 & $2 \frac{1}{2}$ \\
\hline $\begin{array}{l}\text { Lolium italicum } \\
\text { perenne }\end{array}$ & ... & ... & ... & $\ldots$ & ... & ... & $\ldots$ & 6 & $8^{4}$ \\
\hline \multirow{2}{*}{$\begin{array}{c}\text { perenne } \\
\text { Medicago lupulina }\end{array}$} & $\ldots$ & ... & $\cdots$ & $\ldots$ & $\cdots$ & $\ldots$ & $\ldots$ & IO & 12 \\
\hline & ... & ... & ... & $\cdots$ & ... & ... & ... & 2 & 2 \\
\hline \multirow{2}{*}{$\begin{array}{l}\text { Phleum pratense } \\
\text { Trifolium repens }\end{array}$} & ... & $\ldots$ & .. & ... & ... & ... & ... & 3 & 3 \\
\hline & $\cdots$ & .. & ... & $\ldots$ & $\ldots$ & $\ldots$ & ... & 3 & 4 \\
\hline \multirow[t]{2}{*}{ pratense } & renne & $\ldots$ & ... & $\ldots$ & $\ldots$ & $\ldots$ & ... & 2 & 2 \\
\hline & & & & & & & & $36 \frac{1}{2}$ & 44 \\
\hline
\end{tabular}

This class of lands will rarely afford anything more than a very cheap mixture of seeds, such as the above. When, however, the soil is of a moist peaty nature, the quantity of Phleum pratense should be increased, and from I lb. to $\mathrm{I} \frac{1}{2} \mathrm{lb}$. of Agrostis stolonifera and Poa trivialis added. And when it is of a dry nature, and high altitude, an additional quantity of Festuca duriuscula and $F$. ovina, at the rate of $21 \mathrm{~b}$. each per acre, will be found of material advantage, especially for sheep pastures. In addition to which it is always the practice, in some districts, to introduce a few pounds of Plantago lanceolata.

\section{XI.-FOR IMPROVED DEEP MOSSY GROUND, INTENDED TO BE KEPT} IN GRASS

\begin{tabular}{|c|c|c|c|c|c|c|c|c|c|}
\hline \multicolumn{8}{|c|}{ NAMES OF GRASSES } & $\begin{array}{l}\text { With } \\
\text { a } \\
\text { Crop }\end{array}$ & $\begin{array}{l}\text { Without } \\
\text { a } \\
\text { Crop }\end{array}$ \\
\hline \multirow{2}{*}{\multicolumn{2}{|c|}{$\begin{array}{l}\text { Agrostis stolonifera } \ldots \\
\text { Alopecurus pratensis }\end{array}$}} & $\ldots$ & $\ldots$ & $\ldots$ & $\ldots$ & $\ldots$ & $\ldots$ & $\begin{array}{l}10 . \\
2\end{array}$ & $\begin{array}{l}\text { b. } \\
2\end{array}$ \\
\hline & & $\ldots$ & $\ldots$ & $\ldots$ & $\ldots$ & $\ldots$ & $\ldots$ & I & I \\
\hline \multirow{2}{*}{\multicolumn{2}{|c|}{$\begin{array}{cc}\text { Festuca duriuscula } & \ldots \\
\text { pratensis } & \ldots\end{array}$}} & $\ldots$ & $\ldots$ & $\ldots$ & $\ldots$ & $\ldots$ & $\ldots$ & 2 & 2 \\
\hline & & $\ldots$ & $\ldots$ & $\ldots$ & .. & $\ldots$ & $\ldots$ & I & I \\
\hline Lolium italicum & $\ldots$ & $\ldots$ & $\ldots$ & $\ldots$ & $\ldots$ & $\ldots$ & $\ldots$ & 6 & 7 \\
\hline \multirow{2}{*}{$\begin{array}{c}\text { perenne } \\
\text { Lotus major ... }\end{array}$} & $\ldots$ & $\ldots$ & .. & $\ldots$ & $\cdots$ & $\ldots$ & $\cdots$ & 8 & 10 \\
\hline & $\ldots$ & $\ldots$ & $\ldots$ & $\ldots$ & $\ldots$ & $\ldots$ & $\ldots$ & $1 \frac{1}{2}$ & $1 \frac{1}{2}$ \\
\hline \multirow{2}{*}{$\begin{array}{l}\text { Medicago lupulina } \\
\text { Phleum pratense }\end{array}$} & $\ldots$ & $\ldots$ & $\ldots$ & $\ldots$ & $\ldots$ & $\ldots$ & $\ldots$ & 2 & 2 \\
\hline & $\ldots$ & $\ldots$ & $\ldots$ & $\ldots$ & $\ldots$ & $\ldots$ & ... & 4 & 5 \\
\hline \multirow{2}{*}{$\begin{array}{l}\text { Poa trivialis } \ldots . . \\
\text { Phalaris arundinacea }\end{array}$} & $\ldots$ & $\ldots$ & $\ldots$ & $\ldots$ & $\ldots$ & $\ldots$ & $\ldots$ & $2 \frac{1}{2}$ & 3 \\
\hline & .... & $\ldots$ & $\ldots$ & $\ldots$ & $\ldots$ & $\ldots$ & $\ldots$ & I & I \\
\hline \multirow{3}{*}{$\begin{array}{l}\text { Trifolium pratense } \\
\text { repens }\end{array}$} & $\ldots$ & $\ldots$ & $\ldots$ & $\cdots$ & $\ldots$ & ... & $\cdots$ & I & I \\
\hline & $\ldots$ & $\cdots$ & $\cdots$ & $\cdots$ & $\cdots$ & ... & ... & 5 & 6 \\
\hline & & & & & & & & 37 & $42 \frac{1}{2}$ \\
\hline
\end{tabular}


When such grounds are subject to occasional overflowings by fresh water, it will be expedient to add $2 \mathrm{lb}$. or $3 \mathrm{lb}$. of Poa fluitans, and increase the quantities of Agrostis stolonifera, Phleum pratense, Poa trivialis, and Lotus major; in which case a proportionate decrease should be made in the seeds of Lolium italicum, L. perenne, and Trifolium pratense.

\section{XII.-FOR COVERING ROCKY, GRAVELLY, AND OTHER SOILS OF THE WORST DESCRIPTION}

\begin{tabular}{|c|c|c|c|c|c|c|c|}
\hline \multicolumn{5}{|c|}{ NAMES OF GRASSES } & $\begin{array}{l}\text { ROCKY AND } \\
\text { GRAYELLYY } \\
\text { SOILS }\end{array}$ & $\begin{array}{c}\text { DRY } \\
\text { SANDY SOILS }\end{array}$ & $\begin{array}{c}\text { WET } \\
\text { OR } \\
\text { SPONGY SOILS }\end{array}$ \\
\hline \multirow{4}{*}{\multicolumn{2}{|c|}{$\begin{array}{l}\text { Agrostis vulgaris } \\
\quad \text { stolonifera } \quad \ldots \\
\text { Arrhenatherum avenaceum } \\
\text { Brachypodium sylvaticum }\end{array}$}} & & \multirow[b]{2}{*}{$\begin{array}{l}\ldots \\
\ldots\end{array}$} & & $\frac{1 b}{2}$ & lb. & lb. \\
\hline & & & & & $\frac{2}{-}$ & -2 & $\begin{array}{l}2 \\
2\end{array}$ \\
\hline & & $\ldots$ & $\ldots$ & $\ldots$ & 2 & 2 & 2 \\
\hline & & $\ldots$ & $\ldots$ & $\cdots$ & 2 & 2 & 2 \\
\hline Cynosurus cristatus & $\ldots$ & $\ldots$ & $\ldots$ & $\ldots$ & 3 & 3 & 3 \\
\hline Dactylis glomerata & $\ldots$ & $\ldots$ & $\ldots$ & $\ldots$ & 2 & 2 & 2 \\
\hline Elymus arenarius & $\ldots$ & $\ldots$ & $\ldots$ & $\ldots$ & - & 4 & - \\
\hline Festuca rubra $\quad \ldots$ & $\ldots$ & $\ldots$ & $\ldots$ & $\ldots$ & 4 & 8 & - \\
\hline Holcus lanatus $\ldots$ & $\ldots$ & $\ldots$ & $\ldots$ & $\ldots$ & 2 & 2 & 2 \\
\hline mollis ... & $\ldots$ & $\ldots$ & $\ldots$ & $\ldots$ & 2 & 2 & - \\
\hline Lolium perenne ... & $\ldots$ & $\ldots$ & $\ldots$ & $\ldots$ & 10 & 10 & Io \\
\hline Lotus corniculatus & $\ldots$ & $\ldots$ & $\ldots$ & $\ldots$ & I & I & 一 \\
\hline major $\ldots .$. & & & $\ldots$ & & $=$ & - & 2 \\
\hline Medicago lupulina & $\ldots$ & $\ldots$ & $\ldots$ & $\ldots$ & 6 & 5 & 5 \\
\hline Phalaris arundinacea & $\ldots$ & $\ldots$ & $\cdots$ & $\cdots$ & - & - & 4 \\
\hline Phleum pratense & $\ldots$ & $\ldots$ & $\ldots$ & $\ldots$ & 2 & - & 2 \\
\hline \multirow{6}{*}{$\begin{array}{cc}\begin{array}{c}\text { Poa nemoralis } \\
\text { pratensis }\end{array} & \ldots \\
\text { trivialis } & \ldots \\
\text { Trifolium filiforme } \\
\text { repens } & \ldots\end{array}$} & \multirow{6}{*}{$\begin{array}{l}\cdots \\
\cdots \\
\cdots \\
\cdots\end{array}$} & \multirow{6}{*}{$\begin{array}{l}\cdots \\
\cdots \\
\cdots \\
\cdots\end{array}$} & \multirow{6}{*}{$\begin{array}{l}\cdots \\
\cdots \\
\cdots \\
\cdots\end{array}$} & \multirow{6}{*}{$\begin{array}{l}\cdots \\
\cdots \\
\cdots \\
\cdots\end{array}$} & 2 & - & 2 \\
\hline & & & & & 2 & 4 & - \\
\hline & & & & & 2 & - & 4 \\
\hline & & & & & 2 & 2 & - \\
\hline & & & & & 4 & 4 & 4 \\
\hline & & & & & 50 & 53 & 48 \\
\hline
\end{tabular}

In proportion as the soil may be intermediate between those for which the above mixtures are recommended, a discretion must be observed in increasing or diminishing the quantities of the seeds enumerated.

XIII.-FOR MARSHY GROUNDS, AND THOSE OCCASIONALLY OVERFLOWED BY FRESH WATER TIDES

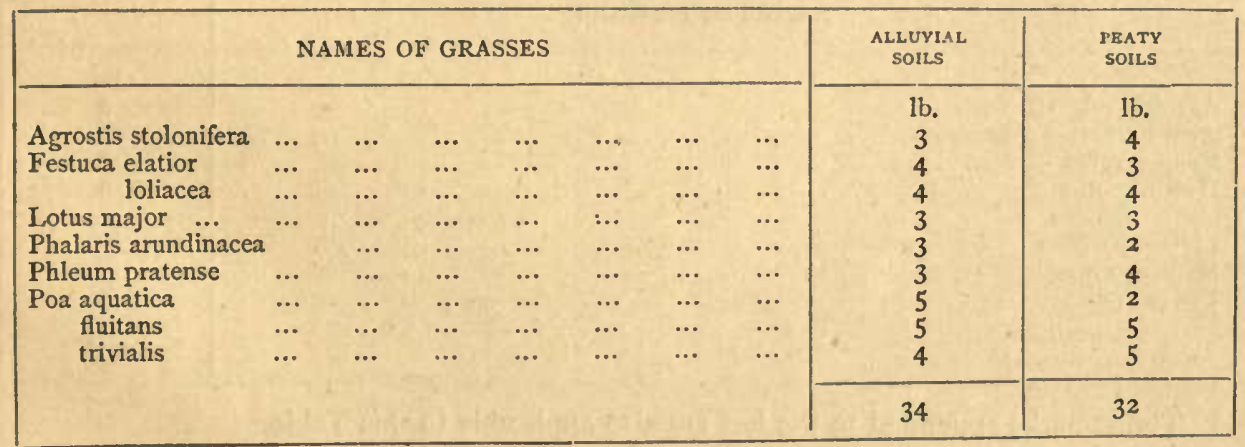


For banks of rivers, subject to occasional overflowings, but where the soil is of a dry porous nature, on an open gravelly subsoil, a mixture approximating to that in Table II. may be used; and the more aquatic grasses, as Poa fluitans, $P$. aquatica, and Phalaris arindinacea, excluded. The two last of these are, however, very useful for preventing the encroachment of rapid running rivers or streams on alluvial haughs, \&c.

\section{XIV.-FOR WARRENS OR LIGHT SANDY LINKS}

\begin{tabular}{|c|c|c|c|c|c|c|c|c|c|c|c|}
\hline \multicolumn{11}{|c|}{ NAMES OF GRASSES } & WEIGHT \\
\hline \multirow{3}{*}{\multicolumn{3}{|c|}{$\begin{array}{l}\text { Achillea Millefolium } \\
\text { Agrostis vulgaris ... } \\
\text { Arrhenatherum avenaceum }\end{array}$}} & & & & & & & & & i. \\
\hline & & & ... & $\cdots$ & $\cdots$ & $\ldots$ & $\ldots$ & $\ldots$ & $\ldots$ & $\ldots$ & 2 \\
\hline & & & $\ldots$ & $\ldots$ & $\ldots$ & $\ldots$ & $\ldots$ & $\ldots$ & $\ldots$ & $\ldots$ & 4 \\
\hline Festuca rubra & $\ldots$ & $\ldots$ & $\ldots$ & $\ldots$ & $\ldots$ & $\ldots$ & $\ldots$ & $\ldots$ & $\ldots$ & $\ldots$ & 4 \\
\hline Holcus mollis & $\ldots$ & $\ldots$ & $\ldots$ & $\ldots$ & $\ldots$ & $\ldots$ & .. & $\ldots$ & $\ldots$ & $\ldots$ & 2 \\
\hline Lolium italicum. & ... & $\ldots$ & $\ldots$ & $\ldots$ & $\ldots$ & ... & $\ldots$ & $\ldots$ & $\ldots$ & $\ldots$ & 6 \\
\hline perenne & $\ldots$ & $\ldots$ & $\ldots$ & $\ldots$ & $\ldots$ & $\ldots$ & $\ldots$ & $\ldots$ & $\ldots$ & $\ldots$ & 8 \\
\hline Lotus corniculatus & $\ldots$ & $\ldots$ & $\ldots$ & $\ldots$ & $\ldots$ & $\ldots$ & $\ldots$ & $\ldots$ & $\ldots$ & $\ldots$ & I \\
\hline Medicago lupulina & $\ldots$ & $\ldots$ & $\cdots$ & $\cdots$ & $\ldots$ & $\cdots$ & $\cdots$ & $\ldots$ & $\therefore$ & $\cdots$ & 4 \\
\hline Onobrychis sativa & $\ldots$ & $\ldots$ & $\ldots$ & $\ldots$ & $\ldots$ & $\ldots$ & $\ldots$ & $\ldots$ & $\ldots$ & $\ldots$ & 4 \\
\hline Poa pratensis & $\ldots$ & $\ldots$ & $\ldots$ & $\ldots$ & $\ldots$ & $\ldots$ & $\ldots$ & $\ldots$ & $\ldots$ & $\ldots$ & 3 \\
\hline Poterium Sanguisor & & $\ldots$ & $\ldots$ & $\cdots$ & $\ldots$ & $\ldots$ & $\ldots$ & $\ldots$ & $\cdots$ & $\cdots$ & 3 \\
\hline \multirow{3}{*}{$\begin{array}{c}\text { Trifolium filiforme } \\
\text { repens }\end{array}$} & $\ldots$ & $\ldots$ & $\cdots$ & $\ldots$ & $\ldots$ & $\ldots$ & $\ldots$ & $\ldots$ & $\ldots$ & $\ldots$ & 2 \\
\hline & $\ldots$ & $\ldots$ & $\cdots$ & $\cdots$ & $\cdots$ & $\cdots$ & $\cdots$ & $\cdots$ & $\cdots$ & $\cdots$ & 3 \\
\hline & & & & & & & & & & & 47 \\
\hline
\end{tabular}

To which may be added, in certain cases, $2 \mathrm{lb}$. of whin (Ulex europoeus), and I $\mathrm{lb}$. of broom seed (Cytisus scoparius). From 2 to $3 \mathrm{lb}$. of lucern seed (Medicago sativa) may also be used when the sand is of a calcareous nature, or mixed with fragments of sea shells. In all cases, the mixture should be sown with a bushel of barley or rye, for the purpose of sheltering the young plants from the scorching droughts and winds to which they will be exposed in such soils.

\section{XV.-FOR DRY GRAVELLY SITUATIONS, WHICH RESIST A SWARD FROM ALL ORDINARY MEANS}

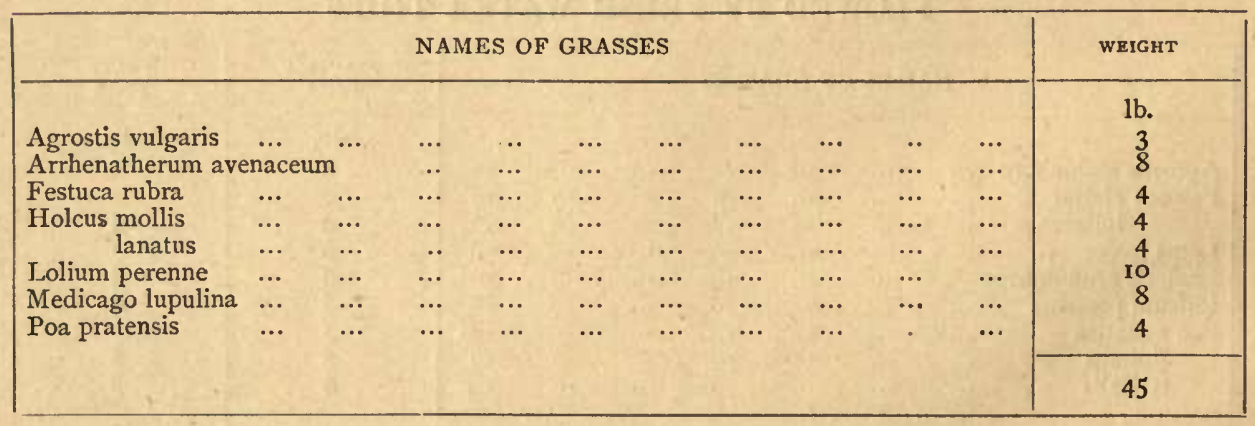

The remarks appended to the last are also applicable to this Table. 


\section{XVI.-FOR DRIFTING OR BLOWING SANDS}

\begin{tabular}{|c|c|c|c|c|c|c|c|c|}
\hline 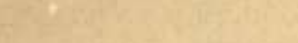 & & NAMES OF & RASSES & & & & & WEIGHT \\
\hline $\begin{array}{c}\text { Ammophila arundinacea } \\
\text { Elymus arenarius } \quad \cdots \\
\text { geniculatus }\end{array}$ & $\begin{array}{l}\cdots \\
\cdots \\
\cdots\end{array}$ & $\begin{array}{ll}\ldots & \cdots \\
\cdots & \cdots \\
\cdots & \cdots\end{array}$ & $\begin{array}{l}\cdots \\
\cdots \\
\cdots\end{array}$ & $\begin{array}{ll}\cdots & \cdots \\
\cdots & \cdots \\
\cdots & \cdots\end{array}$ & $\begin{array}{l}\cdots \\
\cdots \\
\cdots\end{array}$ & $\begin{array}{l}\cdots \\
\cdots \\
\cdots\end{array}$ & $\begin{array}{l}\cdots \\
\cdots \\
\cdots\end{array}$ & $\begin{array}{l}\text { lb. Ib. } \\
8 \text { to I5 } \\
6,, \text { I } 4 \\
2,, 4\end{array}$ \\
\hline & & & & & & & & 16 to 33 \\
\hline
\end{tabular}

To prevent the encroachment of shifting sands, the most effectual means is to sow the seeds of the above-mentioned grasses, over a breadth of 20 to 50 yards, and in certain instances over even as much as 100 and more yards, immediately in advance of such sands. The breadth, as well as the quantity of seeds, per acre, of course, will depend on the obstacles to be overcome. It must, however, be borne in mind, that the liability of such sands to be shifted at times, especially in dry windy weather, almost entirely precludes the possibility of binding them by the agency of seeds alone. Accordingly, various methods have been resorted to for that purpose, but the most generally applicable is to deposit turf, at regular and short intervals, over the surface, and afterwards to sow the seeds of Ammophila arundinacea and Elymus arenarius in the interstices, by mixing them with clay, attached to small pieces of straw ropes, and dibbling these into the sand.

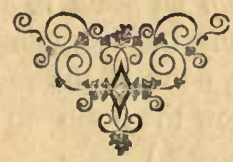




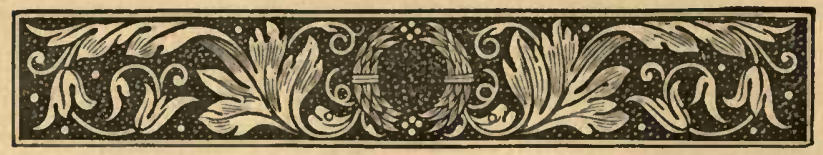

CHAPTER III.

\section{WHICH DESCRIBES IN A POPULAR MANNER THE NATURAL AND ARTIFICIAL GRASSES.}

$\mathrm{T}$

HE following short descriptions of the different grasses recommended in the preceding Chapter have been appended, in the hope that the information therein contained may be useful to cultivators who have not had opportunities of becom. ing acquainted with their characters and qualities.

As many botanical terms occur in the description of the different species and varieties of grasses which may not be sufficiently understood by the agriculturist, we give at the beginning of the book an engraving in which the various parts of a grass are shown with their corresponding names. Considering, however, the popular character of this Treatise, we have avoided the use of scientific terms where we could otherwise explain the meaning with conciseness. We have added the French and German names of each variety described.

\section{$\S 1^{\circ}$ THE NATURAL GRASSES DESCRIBED.}

1. Agrostis alba (Fiorin, or Marsh Bent-grass).-Fr. Agrostide blanche; Ger. Fioringras. - Root perennial, fibrous, grown in marshy or damp soils, but assuming more of a creeping habit when growing on light dry soil; height one foot to one and a half; flowers in July. There is a great number of varieties of $A$. alba, to several of which distinct specific names have been applied: of these may be enumerated $A$. alba var. stolonifera, stoloniferous bent-grass or fiorin; $A$. latifolia, which seems to be the same; $A$.compressa, $A$. sylvatica, and others, which all seem to agree in acquiring a very stoloniferous habit when growing in moist situations, but assuming more of a tufted habit on dry soils. With the exception of $A$. stolonifera, none of the varieties are now of any importance in commerce. It is not advisable to sow the fiorin on any other than a damp or irrigated peaty soil. (See illustration facing page 2.)

Agrostis stolonifera.-See Agrostis alba.

2. Agrostis vulgaris (Common, or Creeping-rooted Bent, Purple Bent, also, Black Switch, Squitch, Twitch, or Quick-grass). - Fr. Agrostide vulgaire; Ger. Gemeines Straussgras. -This grass is distinguished from the preceding and its varieties, by its more loose and spreading panicles, and in the leaves of the sheath being smooth to the touch, whereas in $A$. alba, the sheaths are rough, which may be distinctly felt by passing the finger from above downwards, although smooth in the opposite direction. It has creeping perennial roots, and is mostly confined to dry soils by its less stoloniferous and more tufted habit of growth. Usually considered as a troublesome weed in dry light soils; and, from not being liked by cattle, commonly attracts attention only as being a useless grass, to be 


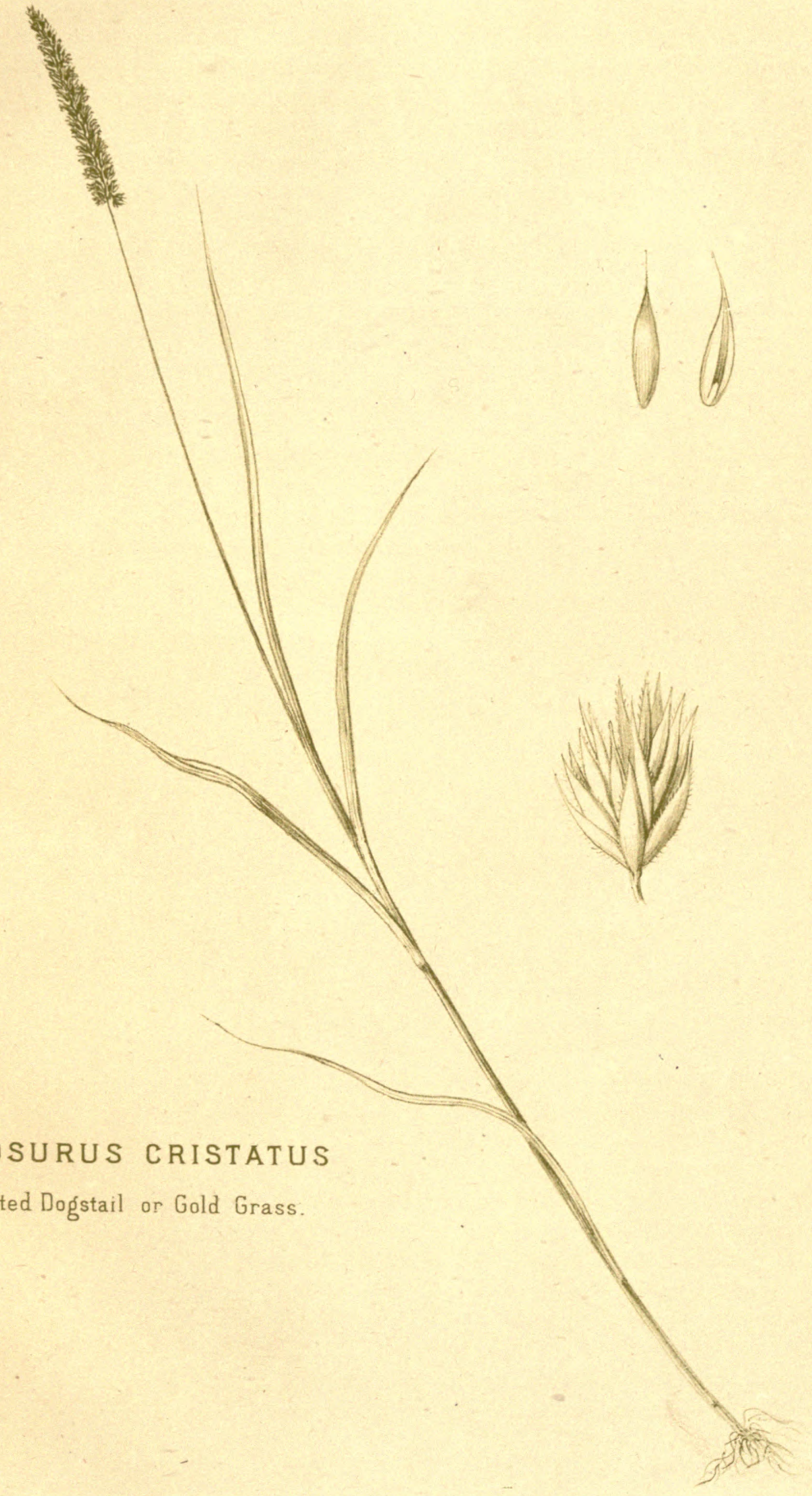



got quit of as soon as possible, more particularly as its creeping roots prove highly injurious to the soil. However, notwithstanding its bad qualities, sheep are found to eat it, particularly in the winter months, and it is sometimes sown on bare gravelly places, where the more valuable grasses will not grow, for the purpose of covering them with vegetation.

3. Aira caespitosa (Tufted Hair-grass).-Fr. Cache touffue; Ger. Rasenschmicle. - Leaves long and flat ; root fibrous, perennial ; height four feet ; flowers in the beginning of August. Grows naturally on rather superior marshy or damp soils, forming large tufts or hassocks, as they are sometimes termed; and as the grass, from its coarse, wiry, and harsh nature, is seldom eaten by domestic animals, it becomes the business of the farmer to extirpate it as soon as possible, not only on account of its unsightly appearance, but because it occupies a considerable portion of the soil which would otherwise be capable of producing more valuable grasses, particularly as it is generally most predominant on the best soils. The $A$. caspitosa may, however, be advantageously sown as a cover for game, especially rabbits and hares, and, in the neighbourhood of ponds and marshes, for snipes and other fowl which frequent those places.

4. Alopecurus agrestis (Slender, or Field Fox-tail-grass, known also as Black Bent). -Fr. Vulpin des champs; Ger. Acker-Fuchsschwanz.-Root fibrous, of biennial duration; flowers in July and August. This grass is generally termed an annual, but it will flower and last two seasons on a light dry soil. It is of comparatively little importance to the agriculturist, and is often very troublesome among wheat. It is, however, useful for sowing along with some others on light sandy soils on the sea-coast, where it will grow much better than any of the common rye-grasses.

5. Alopecurus pratensis (Meadow Fox-tail-grass).-Fr. Vulpin després; Ger. WiesenFuchsschwanz.-Root fibrous, perennial ; flowers in May and beginning of June. This is one of the earliest and best of pasture grasses, but not so well adapted for hay, as it produces few stalks, which are sparingly furnished with leaves; its root leaves are very broad, long, soft, slender, and grow rapidly when cut or eaten down by live stock. Grows naturally on rather superior soils of medium texture, and constitutes the greater portion of many of the richer natural pastures of Britain. It requires two or three years after sowing to arrive at full maturity, and, therefore, it is not suitable for alternate husbandry. (See illustration facing page 4.)

6. Ammophila arundinacea (Sea-Reed, or Mat-grass).-Fr. Roseau des sables; Ger. Sandhafer.-Root creeping, perennial; height one and a half to two feet; flowers in July. The ripe seed, in size and shape, resembles a grain of oats; leaves involute, or rolled inwards at the edges, of a light green colour, hard, sharp-pointed, and rather longer than the culm. It is principally used, along with the Elymus arenarius, in fixing or consolidating shifting sand, for which it is peculiarly adapted by its strong creeping roots, and hard elastic foliage, and for preventing encroachments of the sea.

7. Anthoxanthum odoratum (Sweet-scented Vernal Grass).-Fr. Flouve odorante; Ger. Gemeines Geruchgras.-Root fibrous, perennial; height fifteen to eighteen inches; flowers in May. Grows naturally on dry pastures. This grass yields but a scanty portion of herbage, and is not particularly relished by any kind of live-stock, except, perhaps, sheep; but cattle and horses do not refuse it when mixed with other grasses. Its chief merits, in an agricultural point of view, are its early spring growth, and from its throwing up its root-foliage and flower-stalks until late in autumn. It is remarkable for giving out a pleasant sweet smell during the process of drying similar to that of the sweet-scented woodruff; and it is to the presence of this grass that hay from natural meadows owes its 
peculiar fragrance : this odour is said to be due to the formation of benzoic acid. It has been recommended to be sown in sheep pastures for the purpose of improving the muttona quality which it is supposed to possess and it is founded on the fact that pastures, when it naturally abounds, are known to produce the finest mutton. On the whole, permanent pastures should not be sown without a portion of this grass, particularly in parks and pleasure grounds, were it for no other reason than the pleasant scent which it gives out, not only when cut for hay, but also when the seeds become nearly ripe. Notwithstanding its dwarf growth and the close sward which it forms, it is but ill adapted for sowing on ornamental grounds intended for short grass, on account of its broad foliage, which has rather a coarse appearance. (See illustration facing page 6.)

8. Arrhenatherum avenaceum (Fibrous-rooted Tall Oat-like Grass, French Rye Grass, Common Oat Grass).-Fr. Fausse avoine; Ger. Französisches Raygras.-A fibrousrooted perennial; flowers in July, and yields a considerable bulk of somewhat bitter-tasted herbage, which is not very well relished by cattle. This grass may be found useful for sowing in plantations when the object to be sought is a coarse herbage; but it can scarcely be recommended for ordinary pasture land; for although it quickly reaches maturity, and yields a plentiful herbage until the winter frosts set in, its disagreeably bitter taste causes it to be avoided by horses, cattle, and sheep, when any other kind can be procured, added to which it yields a very small proportion of nutritive matter.

Avena flavescens.-Fr. Avoine jaunâtre; Ger. Goldhafer.-This grass is separated by modern botanists from the genus Avena, and placed under that of Trisetum, which is distinguished botanically from the former, by having the lower palex terminated in two bristle-like points, and an awn proceeding from about its middle, so as to form in all three bristles: hence the name Trisctum.-See. Trisetum flavescens. (See illustration facing page 8.)

9. Brachypodium slyvaticum (Wood Fescue, or Wood Wheat Grass).-Fr. Fétuque sylvatique; Ger. Waldschwingel.-A fibrous-rooted perennial ; leaves of a darkish green and rough; height about two feet ; flowers in July. Grows in moist shady woods and plantations, where it thrives and makes a coarse herbage or under-covering of verdure. It is also found in very dry places, and even on the sea coast. It is a grass not at all liked by any description of domesticated cattle; but is eaten with apparent relish by roe and other deer, and also by hares and rabbits. Its cultivation, therefore, in game coverts may be found desirable, and also in thick shady groves, more especially, too, as it retains its verdure throughout the winter. When its cultivation is desired in very old woods, it can only be successtully accomplished by transplantation from places where it grows naturally, or from nursery beds.

Bromus giganteus.-Fr. Brome géant; Ger. Riesentrespe.-This grass, the Bucetum giganteum of Parnell, is referred by modern botanists to the genus Festuca-See Festuca gigantea.

10. Cynosurus cristatus (Crested Dogstail, or Gold Grass).-Fr. Crételle des prés; Ger. Kammgras.-Leaves short, rather narrow, and taping gradually to the points; root fibrous, perennial; flowers in June and July; height one to two feet. This grass seems to have a wide range of soils. Grows naturally on dry pastures, and also on those where the soil is damp and tenacious; but is most abundant in pastures at low and medium altitudes, and has been found to thrive well in irrigated meadows. Its flower stalks are not eaten by cattle, but allowed to stand and ripen seed; hence it is supposed undeserving of cultivation; but this applies only to the culms and stalks, as all domesticated animals, and particularly sheep, are fond of the root leaves, which, although short, are produced in 


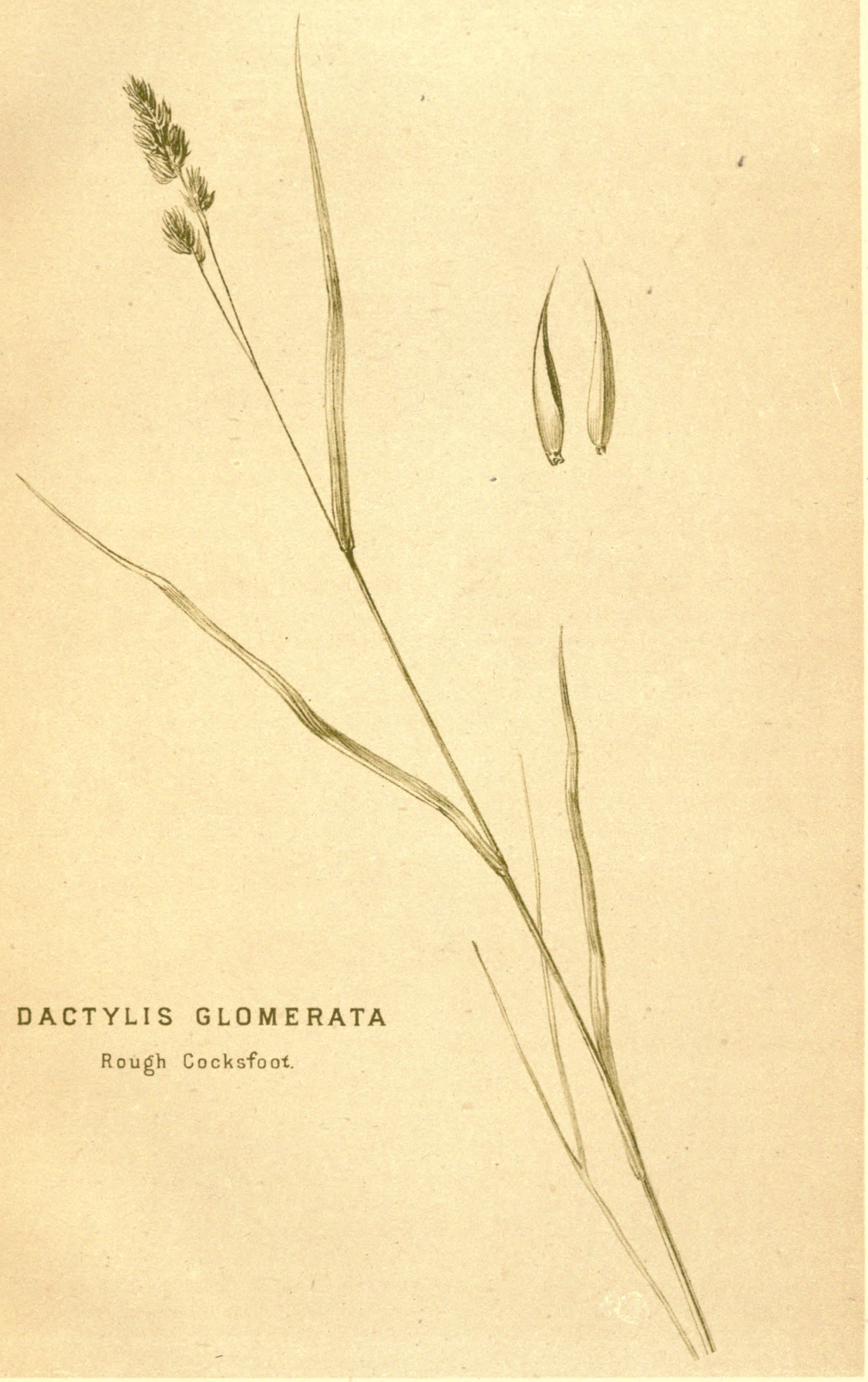



abundance. Sheep are less liable to be affected by the foot-rot, when fed on pastures containing a considerable proportion of this, than on such as are composed of the more tender and soft-leaved sorts. In pasture lands where this grass does not naturally form a portion of the mixture, it is expedient to introduce a little of it ; but, on the other hand, there are many pastures in which it is far too predominant. From its forming a close turf, and having rather fine foliage, it may be advantageously sown on lawns, croquet, bowling and bleaching-greens, and other places which are intended to be kept under the scythe. (See illustration facing page 22.)

11. Dactylis glomerata (Common Rough Cocksfoot, or Orchard Grass).-Fr. Dactyle pclotonné; Ger. Gemeines Knaulgras.-Root fibrous, perennial ; flowers in June and July. The Rough Cocksfoot is a well-known grass, growing abundantly, from one to two feet in height, on all waste places where not very barely cropped by cattle. It is a valuable grass in cultivation, on account of the great quantity of produce which it yields, and the rapidity with which its leaves grow after being eaten or cut. Its habit of growth is tufty, and rather unsightly, with broad foliage, of a slightly glaucous-green colour, which renders it unfit for ornamental parks and pleasure grounds. Sheep are remarkably fond of it, but they should be put to graze upon it early in spring; for if allowed to stand too long, it gets hard and coarse. When subjected to perpetual pasturage the Cocksfoot does not seem to last above five or six years, but gives place to the smaller and finer leaved sorts. This may be accounted for by its spreading very little in the ground, and being in general closely eaten down, particularly by sheep. It is well adapted for growing in shady moist places, under trees, \&c. An extended series of experiments and observations induce us now to recommend the use of this grass in aiternate husbandry, where the land is intended to be kept in grass for two or more years before being again broken up. The Cocksfoot is found to succeed best on land incumbent on a porous subsoil, so that the fibrous roots may have power to penetrate to a considerable depth, under which circumstances the plant thrives very luxuriantly, and is permanent. On a thin soil, with hard subsoil, its success cannot be depended on. In America (from whence it is supposed to have been introduced to Great Britain), it is getting into extensive cultivation, under the name of Orchard Grass. (See illustration facing page 24.)

12. Dactylis crespitosa (Tussac Grass of the Falklands).-Fr. Dactyle cespiteuse; Ger. Buschig Fnaulgras.-Fibrous-rooted, perennial; the fibres very tortuous; stems or culms numerous, erect, branched, or divided only at the base, three or four feet long, smooth, compressed, leafy, and pale yellow, abounding in saccharine matter, and when young, edible even by man; flowers in February and March. The densely matted roots form isolated hillocks or tussocks, three to six feet in height, and three or four in diameter, from which the leaves and stems spring. Several attempts have been made to introduce the 'Tussac Grass into general cultivation on the sea-coasts of this country; but, except in the Orkneys and Lewes, with very indifferent success. Localities within influence of the sea spray, the soil being of a peaty nature, are, without doubt, the best adapted for the growth of the Tussac; and in such places it would be of great service, as few other nutritive grasses will exist there.

13. Elymus arenarius (Sand, or Upright Sea Lyme Grass).-Fr. Elyme des sables; Ger. Strandhafer.-Leaves hard and spiny pointed, of a light glaucous colour, and partly rolled in at the edges; perennial, with powerfully creeping roots; height two to five feet; flowers in July. This grass, both in its green state and as hay, is rejected by all our domesticated animals, owing, no doubt, to its excessive hardness and coarseness. The 
purpose for which $E$. arenarius is generally employed, and for which its creeping matted roots fit it in an eminent degree, is for binding loose sands, and thus to repel the encroachments of the sea, and to prevent the adjoining cultivated land from being overspread by a sandy deposit. It is so used in several parts of Britain, but more extensively on the shores of Holland. The best method of cultivating this grass will be found described at page $2 \mathbf{I}$ of the present Treatise.

14. Elymus geniculatus (Knee-Jointed, or Pendulous Sea Lyme Grass).-Fr. Elyme pendant; Ger. Hängender Strandhafer.-Spikes long and slender, often jointed or bent down as if broken; perennial ; grows naturally on sandy sea shores, but is not common on those of Britain. This plant bears a considerable resemblance to the $E$. arenarius, but differs in its foliage being narrower, and in its spikes, as well as general habit, being more loose or open; its roots are also less spreading. In addition to being useful for similar purposes with the other, its large oat-like seeds afford good food for wild-fowl ; and, from growing in large tufts, to the height of from four to six feet, on almost any sort of soil, it may be beneficially employed as a cover for game, especially in rabbit warrens, and sandy or gravelly links.

15. Festuca duriuscula (Hard Fescue Grass).-Fr. Fétuque durette; Ger. Harter Schwingel.-Stem-leaves broader and more flattened than the root ones, which are rounded or wire-shaped; root perennial, somewhat creeping, and throwing out lateral shoots occasionally; flowers in June and July; height from one and a half to two feet. The Hard Fescues may be classed amongst the best native grasses for general purposes. It will thrive on a great variety of soils, and produce a greater weight of fodder than might be expected from its comparative dwarf habit of growth, and is found to resist the effect of severe drought in summer, and to retain its verdure during winter in a remarkable degree. It constitutes a great portion of the best natural pastures in the country, especially where the soil is light and dry. From the fineness of its foliage and greenness in winter, it is well adapted for sowing in parks and pleasure-grounds, and for sheep pasture; but for short grass to be kept under the scythe, it should, from its wiry nature, enter sparingly into the mixture.

16. Festuca elatior (Tall Meadowe Fescue).-Fr. Fétuque roseau; Ger. Hoher WiesenSchwingel.-This species may be easily distinguished from $F$. pratensis by being much larger (nearly double) in all its parts. It is perennial and fibrous-rooted, somewhat creeping, and forming large tufts; grows from three to five feet high ; flowers in July. Is found naturally on moist superior soils, in waste places, by the banks of rivers, in shady places, and even on the rocky coasts of the sea. It is rather a coarse-like grass, but may be sown either for hay or parmenent pasture, on moist soils, shady places, \&c., where the elevation does not exceed 400 feet. Yields an abundant crop, and, notwithstanding its seeming coarseness, is relished by cattle generally, and is found valuable for those damp soils that cannot be made sufficiently dry for the cultivation of the more valuable grasses.

17. Festuca gigantea (Giant Wood Fescue or Brome Grass).-Fr. Fétuque géante; Ger. Riesen-Schwingel.-Leaves long, very broad, ribbed, and ó a vivid green colour; roots fibrous, perennial, somewhat creeping; height four to five feet; flowers in July and August. In a natural state, where it grows in woods, this grass is rarely found. It yields an immense bulk of herbage, but is not relished by domesticated cattle, except in a dry state and mixed with other grasses. Its nutritive value is small, and its cultivation can only be considered advisable in land too thickly shaded by trees for the growth of better kinds; and in places where its coarse luxuriant herbage and large seeds may render it desirable as a game cover. The seeds are much sought after by small birds. 


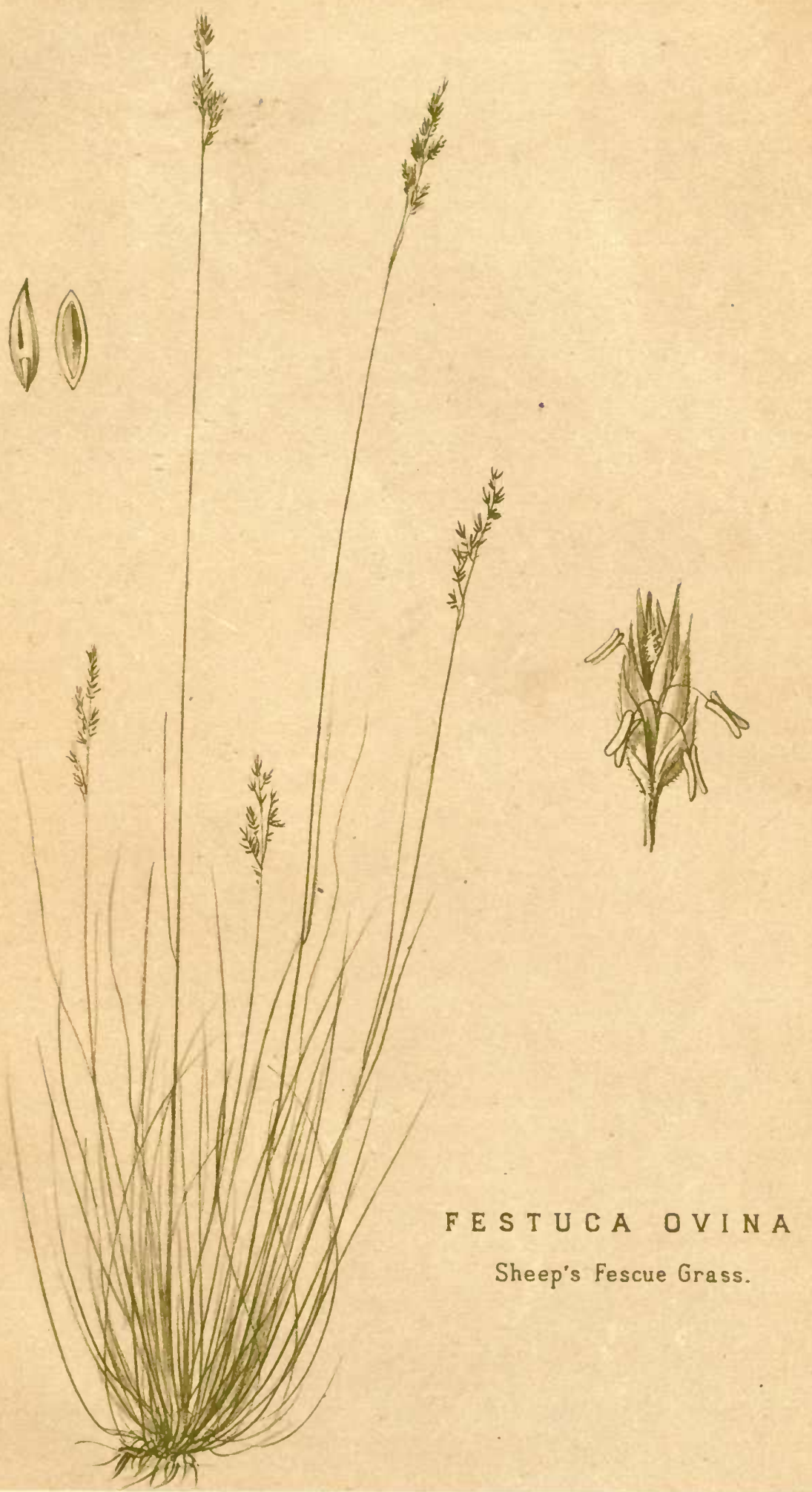



18. Festuca heterophylla (Various leaved Hard Fescue).-Fr. Fétuque hétérophylle; Ger. Ungleichblättriger Schwingel.-Root leaves long, narrow, and flexuous, of a dark green colour; leaves of the culm or stalk, broad, and of a lighter or more vivid green; culms numerous and upright; root fibrous, perennial; flowers in June and July; height four to five feet. This species is a native of France, and introduced to Britain in 1812 . It is grown pretty extensively on several parts of the Continent, particularly in the Low Countries, from whence its seeds are imported. It is well adapted for our climate, and ripens an abundance of seed. For a single crop of hay, it is particularly well suited, and will yield as great, if not a greater, bulk of herbage as any other of the Fescues, but produces little except root-leaves after being cut. Upon the whole, it is well fitted for sowing as a mixture, either on hay or pasture lands, but particularly on the former.

19. Festuca loliacea (Darnel, or Spiked Rye-Grass-like Fescue, Slender Fescue Grass).Fr. Fétuque d'ivraie; Ger. Lolchschwingel.-A fibrous-rooted perennial; flowers in July. In habit of growth and bulk of produce this species much resembles $F$. pratensis, but differs from it in having its inflorescence spiked, as in the Rye Grass, also by being naturally more adapted to grow in marshy situations. It is easily distinguished from the Rye Grass by its spikelets having occasionally a short foot-stalk, always two glumes, and improving in proportion to its age, which is directly the reverse of the Rye Grass. This grass is well suited for marshy soils, and in rich meadow lands which are occasionally overflowed by fresh water.

20. Festuca ovina (Sheep's Fescue).-Fr. F'étuque ovine; Ger. Schafschwingel.Leaves very narrow and rough; stem square; seed small; cylindrical, and pointed at both ends; grows in small tufts; roots fibrous, perennial; height from twelve to eighteen inches; flowers in June and July. This species is easily distinguished from F. duriuscula by its dwarf and more tufted habit of growth, its short, stiff, upright leaves, and, above all, by its square culms or stalks. Grows naturally on light, dry, and sandy soils, and on elevated mountain pastures. The presence of this grass is indicative of the dry nature of the soil, and its consequent adaptability for sheep. It forms the greater part of the sheep pastures of the Highlands. In quantity of produce it is much inferior to the other cultivated Fescues, but from being well liked by sheep, it should always enter into the composition of mixtures for lands on which they are to be pastured. In fact, on the authority of Linnæus, these animals have no relish for hills and heaths which are destitute of this grass. Although the foliage is fine, it is not well suited for sowing on lawns or bowling-greens, on account of its small tufted habit of growth, and the difficulty experienced in cutting it with the scythe. A variety ( $F$. ovina var. temuifolia), the $F$. tenuifolia of some botanists, grows naturally in great abundance with the species in many of the dry pastures of France, and may be met with occasionally in Britain. It differs from the species in being of a less tufted habit of growth, having shorter stems or culms, looser panicles, awnless, smaller seeds, and much longer and slenderer leaves, which are of a light vivid green colour. Is of little importance in field culture, but well suited for sowing in ornamental pleasure-ground. (See illustration facing page 26.)

21. Festuca pratensis (Meadow Fiescue Grass).-Fr. Fétuque des prés; Ger. WiesenSchwingel.-Leaves broad, and of a lively green colour; root fibrous, perennial; height generally from two to three feet; flowers in June and July. This is an excellent grass, either for alternate husbandry or permanent pasture, but more particularly the latter, combining most of the properties without the defects of Common Rye Grass. When growing naturally, it is generally found on superior, rather moist soils, and often forming 
a considerable portion of the natural pasture; but does not thrive well on dry soils. Makes excellent hay, and though a large plant, the leaves of the herbage are succulent and tender, and apparently much liked by cattle, as they never form rank tufts, as is the case with the larger grasses. (See illustration facing page 28.)

22. Festuca rubra (Red, or Creeping Fescue).-Fr. Fétuque rouge; Ger. Rother Schwingel.-This is considered by some as merely a variety of the $F$. duriuscula, slightly altered in habit, from growing always on light dry sandy soils. It is distinguished, however, by its creeping roots, broader and generally darker-coloured foliage, and producing a smaller number of stems. From its creeping-rooted habit, it is comparatively of little use to the agriculturist, except for sowing on light sandy sea coasts, after the shifting sand has been partially consolidated, and on the slopes of railway cuttings and embankments, where the soil is dry.

23. Holcus lanatus (Woolly Soft Grass, Meadow Soft Grass, or Yorkshire Fog).Fr. Houque laineuse; Ger. Honiggras.-Leaves downy ; root fibrous, perennial; height one to two feet; flowers in June and July. Grows naturally on inferior light soils, and particularly on such as have a little peat in their composition, and are of a dampish nature. The H. lanatus is very productive and easy of cultivation, but is of little value for either hay or pasture. It yields a large bulk of aftermath, which, lowever, is not liked by cattle, either in a green state or when made into hay, owing, it is supposed, to its soft spongy nature, and from not having a sufficiency of a sub-acid or saline taste, its nutritive matter, according to Sir Humphrey Davy, consisting entirely of mucilage and sugar. This property may in some degree be overcome by sprinkling a little salt over it when stacking, or before giving it to cattle. Where the soil is fitted for other grasses, $H$. lanatus can only be considered as a troublesome weed, and all means should be used for its extirpation. This and the following species of Holcus are distinguished from all the rest of our common grasses by the soft and woolly appearance of their panicles: those of $H$. lanatus assume a great variety of shades in colour, from a white to a beautiful red, but generally on a whitish ground., (See illustration facing page 30.)

24. Holcus mollis (Creeping Soft Grass, or Beardcd Soft Grass).-Fr. Houque molle; Ger. Weiches Honiggras.-Root perennial, creeping, sometimes from three to five feet in length; leaves pale green and roughish; flowers in July. This is easily distinguished from the preceding species, by producing fewer culms, having looser panicles, longer awns, broader foliage, and powerfully creeping roots; grows naturally in a great variety of soils, but principally in dry woods, bushy places, and waste ground. It is possessed of no property to recommend it for cultivation, and can only be considered useful for sowing in wooded and barren, dry, or gravelly grounds. Its creeping roots, however, render it useful for fixing dry sandy slopes, railway embankments, \&c. Where it abounds naturally in good pastures it should be extirpated to make room for superior sorts.

25. Lolium italicum (Italian Rye Grass).-Fr. Raygras d'Italie; Ger. Italienisches Raygras.-A fibrous-rooted grass, of biennial or triennial duration; native of the south of Europe; flowers in May and June. Introduced by us from Italy in 1833 . The most marked distinction between this and $L$. perenne is in the lower paleæ being terminated by an awn or beard, the varieties of the latter being all beardless. Botanists, however, agree in concluding that the presence or absence of the awn in Graminea does not constitute a sufficiently permanent character, from its being often caused merely by the effects of climate, soil, \&c. Hence it has been concluded, the Italian Rye Grass is 


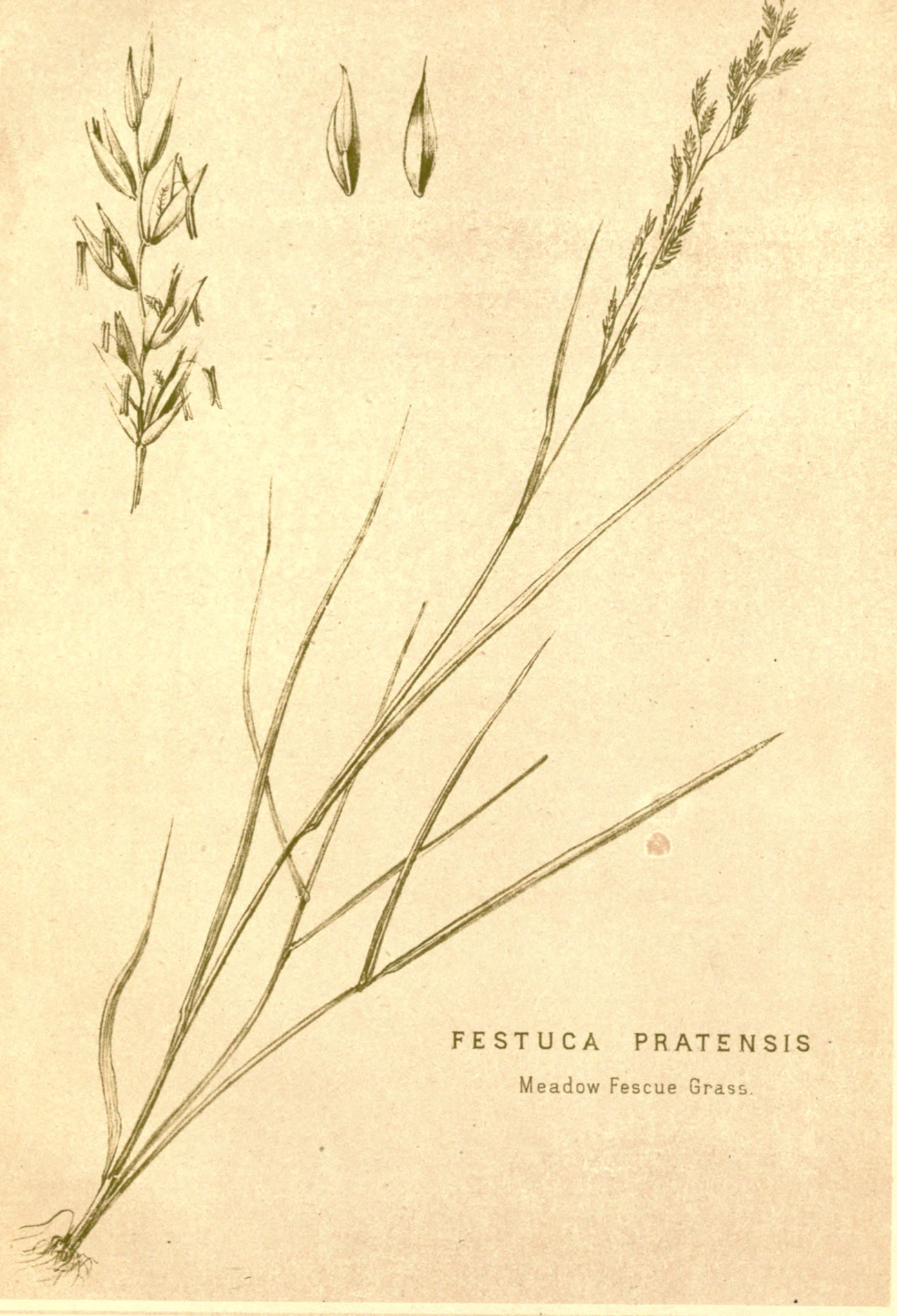



only a varicty of $L$. perenne. The former, liowever, possesses other distinctive characters, which, although they may seem of little consequence in the estimation of the botanist, are, nevertheless (some of them at least) of considerable importance to the agriculturist. Compared with any varieties of Common Rye Grass, the L. italicum affords a stronger braird, arrives sooner at maturity, has a greater abundance of foliage, which is broader, and of a lighter or more lively green colour, grows considerably taller, is more upright, or less inclined to spread on the ground; its spikes are longer; spikelets more thinly set, and, upon the whole, producing a less bulk of seed, which is smaller; has the awn (above mentioned) adhering to it, and is generally about two-thirds the weight per bushel of that of Common Perennial Rye Grass, when grown under similar circumstances. Another of its distinguishing characters is, that it is preferred by cattle to any of the common sorts, a fact which has been proved by numerous experiments in various parts of the country, while it yields early, bulky, and quickly succeeding herbage, which renders it an invaluable grass for alternate husbandry. Its comparatively limited duration fits it well for sowing in mixture with the other grasses intended for permanent pasture, as it dies out and gives place to the weak or slowly maturing perennial sorts, which are destined ultimately to fill the ground. General experience since our first introduction of the Italian Rye Grass to Britain, enables us to state, that, in respect to duration, it may be termed a sub-perennial, beyond which title even the most permanent varieties of $L$. perenne have no claim. In most instances, two seasons of Italian Rye Grass are all that can, with any degree of certainty, be depended upon; and in very wet, cold, spongy soils, it will often exhibit a thin stock the second season. Instances have, however, occurred, in which as many as five and six successive years' produce have been reaped from the same field, yielding annually, on an average, about seven and a half tons of dry hay per acre; but this has arisen more from the ground having been resown in course of reaping the seed, than from the actual duration of the original plants; the seeds being remarkably easily separated from the hay, even although not perfectly ripe, which will always render the harvesting of them an operation attended with considerable care and difficulty. Although the natural tendency of the Italian Rye Grass is to produce many stalks or stems from the same root, yet, from its upright habit of growth, it by no means forms a close turf; hence the propriety of sowing it with a mixture of other grasses of a different habit, which, by filling up the interstices, will add considerably to the weight of produce. Only one opinion is now entertained as to the real merits of the Italian Rye Grass, and the best proof of its excellence is the great and yearly increasing demand for its seeds. (See illustration facing page $3^{2}$.)

26. Lolium perenne (Common Rye Grass).-Fr. Raygras d'Angleterre; Ger. Enslisches Raygras.-A fibrous-rooted grass of biennial, triennial, or quadrennial duration; flowers in June and July. Grows naturally in meadows and rich pastures. Possesses several good qualities to recommend it to the attention of cultivators, the principal of which areits suitableness to a great variety of soils, the facility with which it is propagated, by reason of its seeds being produced in abundance, and their uniformity in ripening; and, although last, not the least of its good qualities, the fibrous structure of its roots, which fits it in an eminent degree for alternate husbandry. Like other plants which have received an extensive cultivation, there are several varieties of the Common Rye Grass. Those of the most perennial habits, which are distinguished by their yielding a great abundance of root leaves and fewer stalks or culms, are denominated Perennial; and those of shorter duration, which generally produce a smaller quantity of root leaves and a greater number of culms, 
are, for distinction only, termed Annual; but even these last will, under favourable circumstances, exist two or three years, while under unfavourable circumstances the most esteemed perennial varieties will scarcely exist more than one or two years. See illustration facing page 34 .

1. Evergreen.- This variety does not yield such a bulky crop as the ordinary kind, but it is still more perennial in its nature, and withstands the rigour of winter well, retaining its verdure throughout the year. It is a very good variety for sowing in ornamental grounds. Known, also, as Devon Evers.

2. Fine-leaved.-This variety (L. perenne tenue) is distinguished for the fineness of its foliage, qualities which recommend it for sowing down ornamental grounds.

3. Pacey's. - This variety produces an abundance of foliage, both at the roots and on the stalks, and from its perennial character is well adapted for pleasure grounds and permanent pasture.

27. Milium effusum (Wood, or Spreading Millet Grass).-Fr. Millet divergent; Ger. Wald-Hirsengras. - A fibrous-rooted perennial; flowers in June; grows naturally in old woods and copses, and most frequently on rich vegetable soils composing the shelving and sloping banks of rivers, where it usually attains a height of from four to six feet. The abundance of seed which it produces, together with its naturally preferring to grow in the cool and shade of trees, recommend it for game preserves. Every part of the grass is relished by cattle, and the aftermath comes away freely, even after the first crop has been allowed to ripen seed.

28. Phalaris arundinacea (Reed-like Canary Grass).--Fr. Alpiste roseau; Ger. Rohrartiges Glanzgras.-Root creeping, perennial; height four to six feet; flowers in July. Grows naturally on alluvial and tenacious clayey soils, by the sides of rivers, lakes, pools, \&c. This grass contains a considerable proportion of nutritious matter; but, from its coarseness, cattle in general refuse it, although they eat it if cut into chaff prior to flowering, and mixed with other food. It yields a large bulk of hay, which in some parts is found very convenient for littering cattle.

29. Phleum pratense (Timothy, or Catstail Grass).--Fr. Fléole des prés; Ger. Thimoté-gras.-Root perennial, somewhat creeping; leaves flat and roughish ; height from one and a half to two feet ; flowers in the end of June. In America this grass is cultivated, where the soil is favourable, to exclusion of almost all other kinds; and in Britain it is also grown to a considerable extent, particularly in some districts of England. It thrives best on moist soils or carse lands, and also on newly-reclaimed moorish soils. When grown on dry light soils its roots become bulbous or tuberous. The Timothy Grass possesses the advantage of affording a much greater quantity of nutriment when its seeds are ripe than it does if cut when in flower; hence an increased stimulus is given to its cultivation, from its seeds being procured without its being lessened in value as a hay crop. On tenacious, strong, and rather moist soils, it is entitled to precedence of almost any other, and should at least form a considerable proportion of the mixture employed for sowing them down, either for alternate husbandry or permanent pastures. Compared with several others, it is, however, rather deficient as an early spring grass, but is equal to any of the varieties of Common Rye grass. (See illustration facing page 36.)

30. Poa alpina (Alpine Meadow Grass.-Fr. Paturin alpin; Ger. Alpen Rispengras. -Root perennial, fibrous, and of a tufted habit; leaves short and rough on the edges and inner surface; height from four to twelve inches; flowers in June. Grows naturally at very high elevations, but thrives, also, in low-lying districts. This is a valuable grass for 


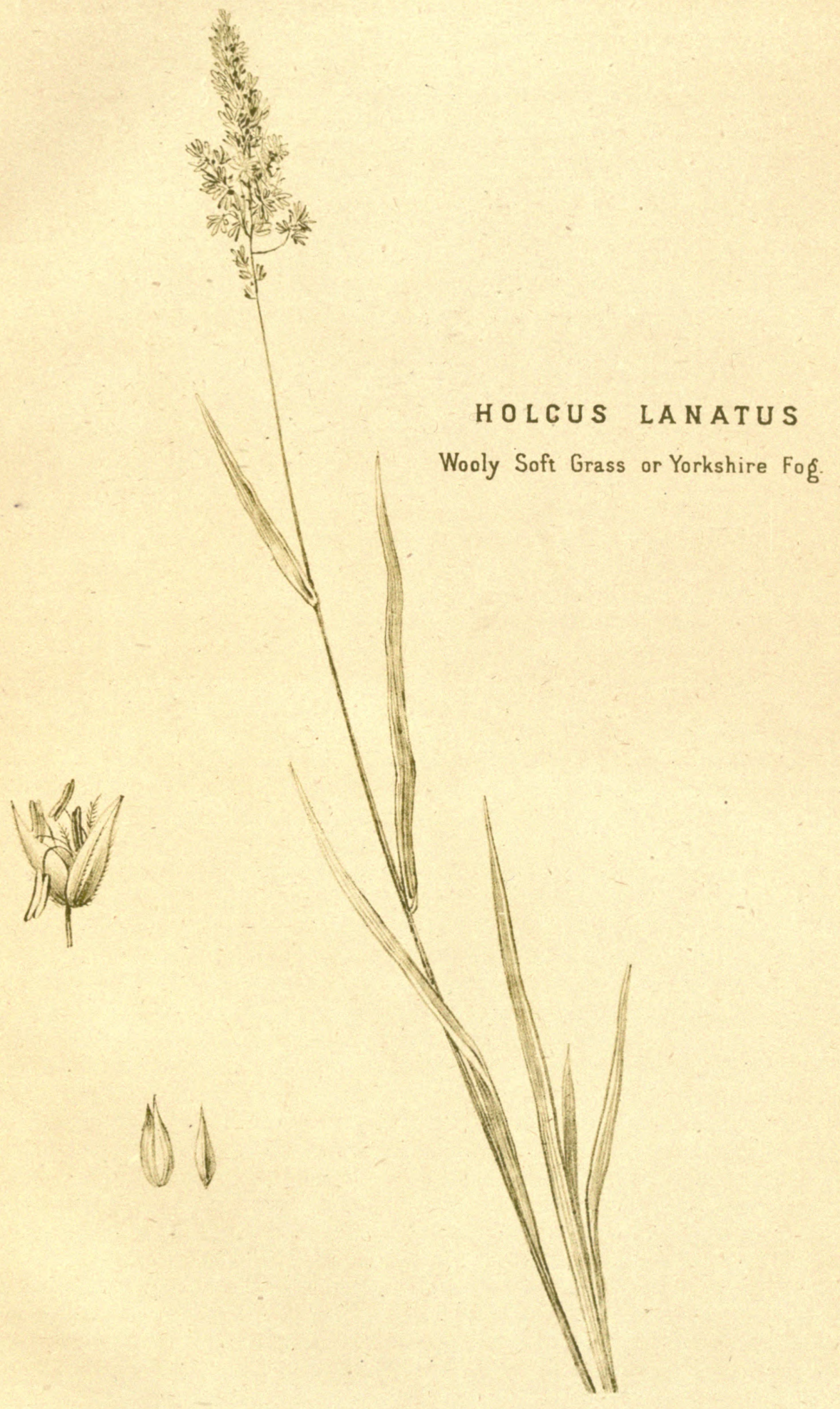



lofty mountain pastures, where its extended culture would be attended with advantage; for scarcely any other grass will succeed at so great an elevation.

31. Poa annua (Annual Meadonv Grass).-Fr. Paturin annuel; Ger. Einjähriges Rispengras.-Stem slightly compressed ; roots fibrous, annual ; average height about nine inches; in flower most part of the year. The $P$. anmua is the most common grass in all temperate climates, and generally considered as a very troublesome weed. From its being greedily eaten by cows and sheep, it has been recommended as a pasture grass; but there are two obstacles which tend to prevent its cultivation: viz., the difficulty with which its seeds are collected, owing to the irregularity in which they arrive at maturity, and from being easily shaken out when ripe; and the small bulk of produce. It has, however, been beneficially employed for sowing on greens and bleaching grounds, in towns and places where the perennial grasses are apt to be destroyed in winter. In summer it will ripen its seeds in four or five weeks from the time of sowing. (See illustration facing page 38.)

32. Poa aquatica (Water Meadow Grass, or Reedy Water Grass).-Fr. Paturin aquatique; Ger. Wasser Rispengras. - Leaves long, broad, tapering to the point, and of a vivid green colour; root powerfully creeping; height about six feet on an average, but often much more; flowers in the latter end of July. Grows naturally in and by the sides of muddy pools, fresh-water lakes, and sluggish rivers, also on rich alluvial soils, more especially on the banks of rivers, where occasionally covered by fresh-water tides. Yields an immense bulk of coarse nutritious herbage; but is apt, by its rapid growth and creeping roots, to choke up ditches and small streams. It is one of the tallest, and, at same time, the most productive in herbage of all the British grasses.

33. Poa fluitans (Floating Szveet Meadozv, or Water Grass).-Fr. Paturin flottante; Ger. Schwimmendes Sïssgras.-Leaves long, broad and floating when in deep water; root fibrous; height two to three feet. Flowers from May to the end of August. Grows naturally in and by the sides of ditches, pools, rivers, and on alluvial fresh-water marshy soils generally; and is eaten with avidity by horses, cattle, sheep, and swine. It has been said not to thrive except when constantly in water; but there are few grasses better adapted for irrigated meadows, and even on moderately dry ground it will yield a considerable produce. Besides being useful as a herbage and forage plant, its seeds are greedily eaten by wild ducks and other marsh fowls; also by trout and other fresh-water fish. They are very nourishing, and form the mannakroop of the shops (the Semolina of commerce), and are used in soups and gruel. They are rather difficult to collect, in consequence of their irregularity in ripening, and from being easily shaken out when ripe.

34. Poa nemoralis (Wood Meadow Grass).-Fr. Paturin des bois; Ger. Hainrispengras.-Leaves plaited at the base, broader and longer than the sheath; culm of foot-stalk slender, but pretty upright; root fibrous, or slightly spreading, when growing in light sandy soil; flowers in June and July ; height from one and a half to three feet. This grass, as its name implies, is found naturally in shady woods, particularly in alpine situations, and is well adapted for growing under trees; but will also thrive on exposed places, and even on inferior light soils. Its habit of growth is delicate, upright, close, and regular, with the panicles partially drooping, or bending, when nearly ripe. There is no grass better adapted for pleasure grounds, particularly under trees, as it will not only grow in such places, but form a fine sward, where few of the other fine grasses can exist. It produces foliage in abundance early in spring, but grows rather slowly after being cut for seed. From the closeness of its habit of growth, it is found to displace annual and biennial weeds, and also those of 
more permanent duration, provided it be allowed to run to seed. There are several varieties of $P$. nemoralis in cultivation, the most important of which is the Evergreen, or Hudson's Bay Meadow Grass ( $P$. nemoralis, var. sempervirens). The recommendatory characteristics of the Hudson's Bay Grass are its perpetual greenness, earliness in spring, and the rapidity with which it reproduces leaves and stems after being eaten or cut down; in addition to which, its thick growth, fineness of foliage, and capability of growing under the shade of trees, like the common $P$. nemoralis (from which it cannot be considered specifically distinct), render it a most desirable grass for lawns and ornamental parks.

35. Poa pratensis (Smooth-stalked Meadow Grass).-Fr. Paturin des prés; Ger. Wiesen Rispengrass.-Root creeping; stem smooth; leaves hardish and roughish; height two feet; flowers in May and June; grows naturally in very dry situations, as on rocks, and tops of walls. This grass has been greatly recommended for pasture, from its yielding a large quantity of herbage at a very early period of the season; but it possesses several bad properties, which render the propriety of its culture at least doubtful, except, perhaps, in very dry soils, where the more valuable grasses are liable to suffer from drought. Its creeping roots impoverish the soil, and its foliage ceases, in a great measure, to grow after the month of June; while it is liable to be injured by the disease called rust, and from its growing in large patches, all the other grasses within its reach are destroyed. When intended for hay it should be cut while in flower; for if allowed to ripen its seed, a considerable loss will be sustained. (See illustration facing page 40.)

36. Poa trivialis (Rough-stalked, Stoloniferous Meadow Grass).-Fr. Paturin Commun; Ger. Gemeines Rispengras. - Leaves rather smooth; producing shoots from the base of the culms, which trail on the ground, and make small roots at their joints in moist weather; root fibrous, perennial ; flowers in June and July; height, two to two and a half feet. This is a valuable grass as a mixture for pasture lands, particularly on damp soils, and where partly shaded by trees; and is well suited, with Agrostis alba var. stolonifera and Poa fuitans, for irrigated meadows. Its stoloniferous shoots begin to grow pretty early in spring, and by lying prostrate on the ground form a beautiful verdant sward. As the season becomes more advanced, however, these shoots are dried up by the effects of the sun, but they shoot out again towards the end of the season, when the weather becomes more moist, and continue green during the greater part of the winter; a habit of growth which fits it for mixing with the upright growing sorts, such as the Italian Rye Grass. Although possessed of tender foliage, and easily cut with the scythe, it is not adapted for sowing for short grass, as it is apt to get dried up in summer, while its creeping shoots are liable to be raised by the rake or broom in clearing off, thus giving the work an unfinished appearance. (See illustration facing page 42.)

37. Trisetum flavescens (Yellowish Oat Grass).-Fr. Avoine jaunâtre; Ger. Goldhafer.-Root fibrous, perennial; height one and a half to two feet ; flowers in July. Grows naturally in dry pastures, on rather light and good soils, and is eagerly sought after by sheep. The $T$. Alavescens yields a considerable bulk of fine herbage, and deserves to form a portion of all mixtures on light dry soils, either for hay or pasture; but is one of those grasses which never thrive unless combined with others. It arrives early at maturity, and although a perennial, yet, if allowed to ripen seed, is but of short duration, particularly if grown on stiff moist soils. 


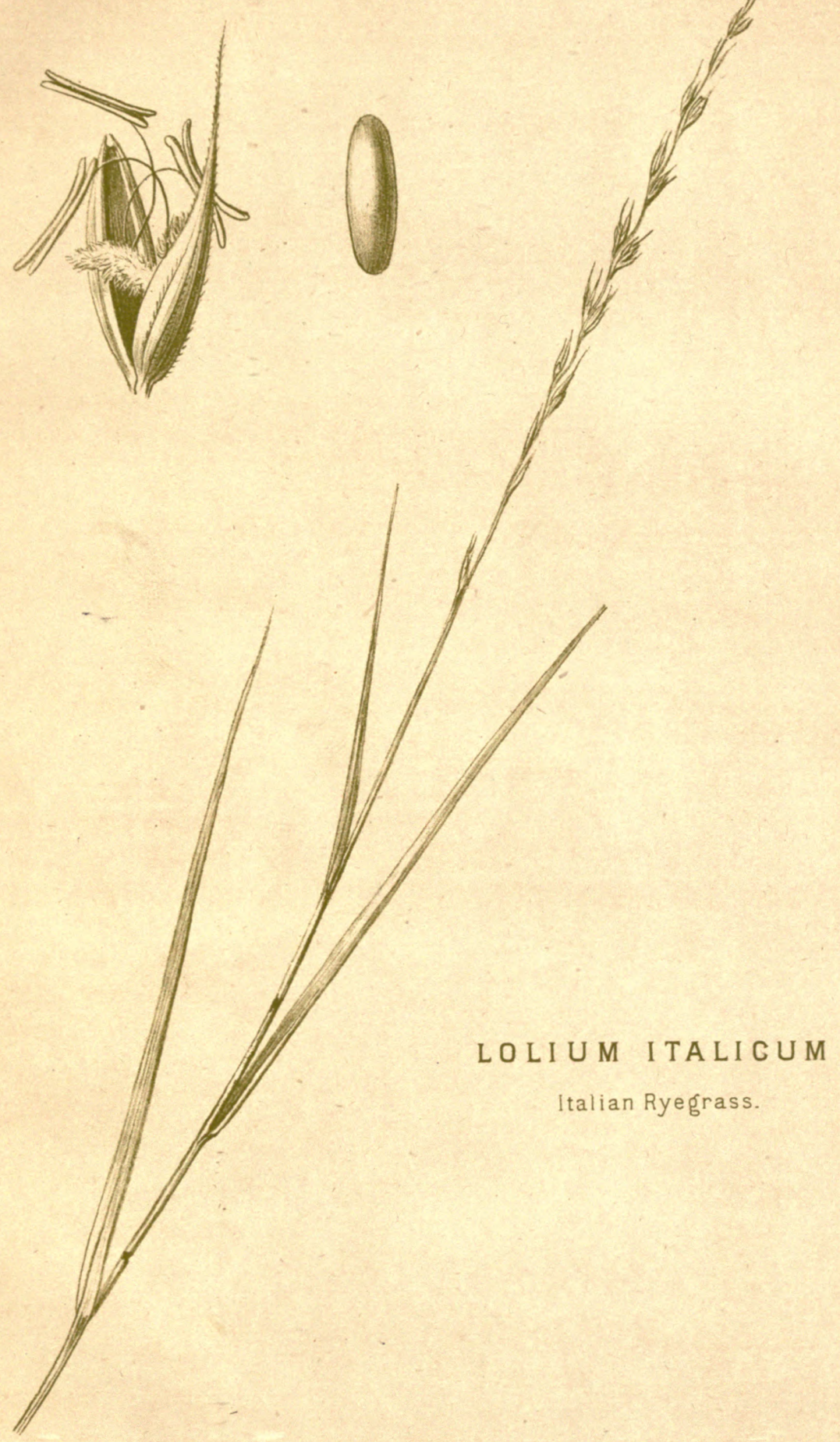





\section{LIST OF SYNONYMS}

Agrostis stolonifera, Koch Sce Agrostis alba.

Ammophila arenaria, Koch - Ammophila arundinacea.

Arrhenatherum elatior, Koch - Arrhenatherum avenaceum.

Arundo arenaria, Smith, Hooker.

- Ammophila arundinacea.

Avena elatior, Linn.

- Arrhenatherum avenaceum.

Avena flavescens, Smith, Hooker, Koch..... - Trisetum flavescens.

Bromus giganteus, Linn., Hooker -.. Festuca gigantea.

Bucetum elatius, Parnell - Festuca elatior.

Bucetum giganteum, Parnell

- Festuca gigantea.

Bucetum loliaceum, Parnell.

- Festuca loliacea.

Buçetum pratense, Parnell

- Festuca pratensis.

Deschampsia cæespitosa, Lindley.

- Aira crespitosa.

Festuca sylvatica, Smith

- Brachypodium sylvaticum.

Festuca tenuifolia, Schrader.

- Festuca ovina var. tenuifolia.

Festuca fluitans, Linn.

- Poa fluitans.

Glyceria fluitans, Smith, Lindley.

- Poa fluitans.

Glyceria aquatica, Smith

- Poa aquatica.

Holcus avenaceus, Smith, Hooker

- Arrhenatherum avenaceum.

Hydrochloa aquatica, Lindley

- Poa aquatica.

Poa nervosa

- Poa nemoralis var. sempervirens.

Psamma arundinacea, Lindley

- Ammophila arundinacea.

Schedonorus pratensis, Lindley

- Festuca pratensis.

Schedonorus elatior, Lindley

- Festuca elatior.

Triticum sylvaticum, Parnell

- Brachypodium sylvaticum. 


\section{$\S 2^{\circ}$ CLOVERS AND OTHER PLANTS}

\section{GENERALLY TERMED ARTIFICIAL GRASSES}

1. Achillea Millefolium (Yarrow, or Common Milfoil).-Fr. Achillée Millefeuille; Ger. Schafgarbe.-A fibrous-rooted perennial; flowers in June, July, and, occasionally, in the succeeding months. Leaves slightly hairy, and cut into a number of partitions; flowerstalks furrowed; root stems, which creep on the ground, striking root in the soil during damp weather; flowers generally white, but occasionally pink, and sometimes even deep red; grows naturally in dry pastures on light soils. The Yarrow is highly astringent, and reckoned a grateful food for sheep, when mixed with the common pasture grasses; but it is more as a condiment that it is to be considered than as affording direct nutritive matter. It is, therefore, generally sown in mixtures with such seeds as are reckoned best adapted for permanent sheep pasture, and in soils where it is found naturally to thrive. This plant may with advantage be sown on the poorest and driest pasture, and is capable of withstanding the most excessive drought. In rabbit warrens, dry sandy slopes, and on railway cuttings or embankments it may advantageously be introduced.

2. Cytisus scoparius (Common Broom).-Fr. Genet; Ger. Pfriemenkraut.-This well-known plant has been recommended for sowing in pastures for sheep, to afford them a supply of winter food; but although they are found to eat it when grown naturally within their reach; yet from its excessive bitterness, and the diuretic qualities ascribed to it, it may be questioned whether they do not do so rather by way of medicine than for actual nourishment. The propriety of introducing Broom to a great extent is doubtful, particularly as it invariably produces bad effects when eaten in large quantities.

3. Lotus corniculatus (Common Birdsfoot Trefoil).-Fr. Lotier corniculé; Ger. Grobkörniger Schotenklee.-A prostrate deep-rooting perennial ; flowers eight or ten, generally of a bright yellow, but sometimes orange-coloured, especially before being fully expanded; stem decumbent, smooth; root thick and fusiform; flowers about the end of June, and continues till the end of August. Height from six inches to one foot. Grows abundantly on dry elevated pastures, sandy links, and heathy places. This plant is well deserving of cultivation on light dry and very elevated inferior soils, where it will yield a greater bulk of herbage than any of the cultivated clovers. It is highly nutritious, quite equal to any of the clovers, and eaten with avidity by cattle. From the great depth to which its roots penetrate, it is not liable to be injured by drought, and is thereby enabled to retain its verdure after the grasses and other plants are burnt up.

4. Lotus major (Greater Birdsfoot Trefoil).-Fr. Lotier majeure; Ger. Hoher Schotenklee.-A spreading or creeping-rooted perennial ; flowers in July and August; grows naturally in moist situations, by the sides of ditches, damp hedges, osier beds, and bushy places, and attains its greatest luxuriance in soils which have a portion of peat in their composition. Possesses several good properties with the last, but yields a much greater bulk of herbage. It is distinguished from $L$. corniculatus by its more luxuriant habit, also in the form of its roots, which are fibrous and creeping, while those of the latter are thick and fusiform, characteristics which both retain when cultivated under any circumstances.

5. Medicago lupulina (Common Yellow Clover, or Trefoil, Nonsuch, Black Medick Lupuline).-Fr. Minette jaune; Ger. Gelbklee.-A fibrous-rooted biennial or sub-perennial; flowers from May to August; grows in dry pastures and cultivated grounds. This 


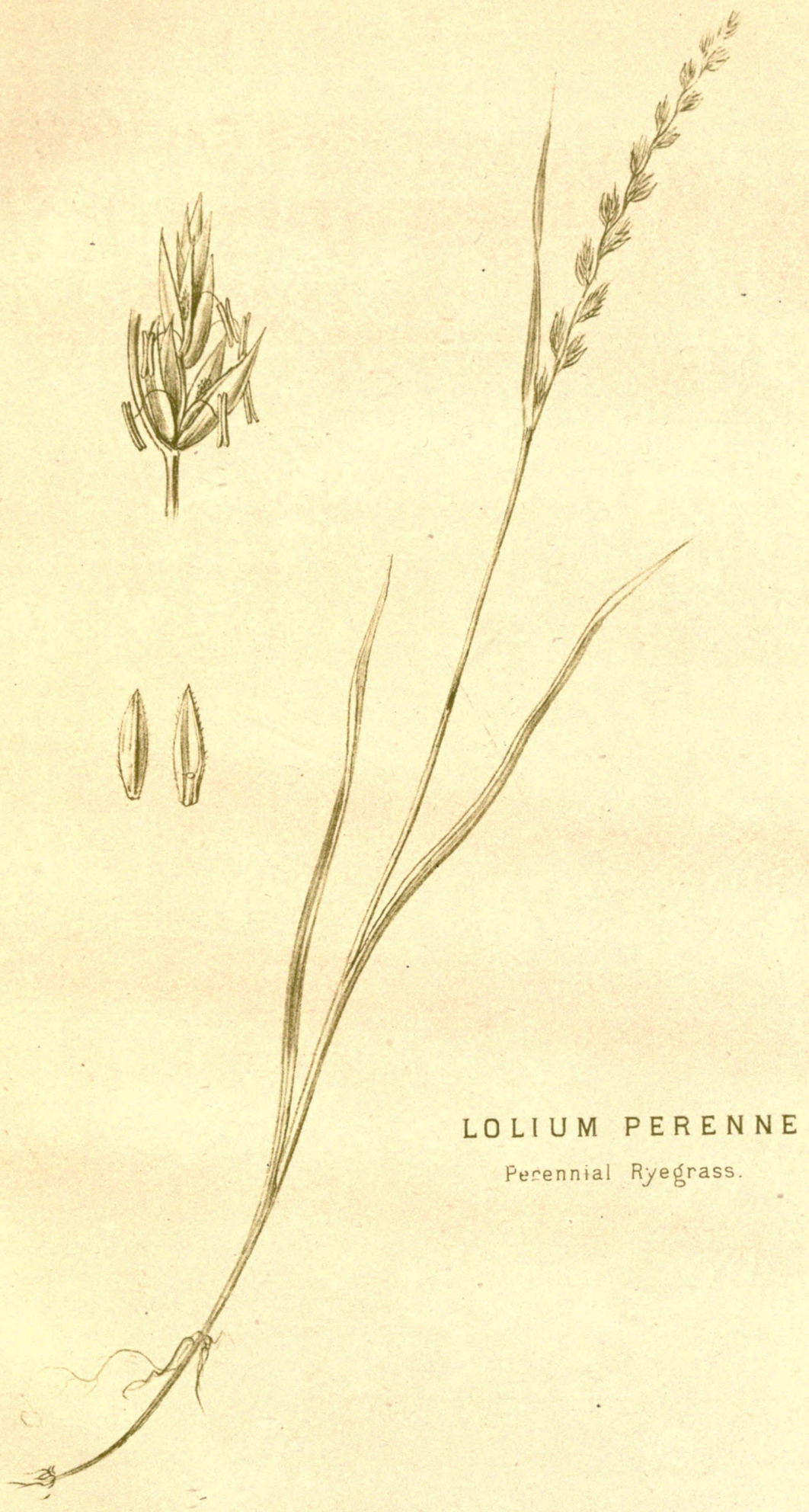



plant has been cultivated in mixture with Red Clover and Rye Grass, for a great length of time. Its seeds, which are produced in much greater abundance, are consequently cheaper than those of any of the other clovers; and it is questionable whether this circumstance may not contribute to the extensive cultivation which it receives, more than any superior merit. Although the produce is bulky, cattle are not generally fond of it, either in a green or dry state, and only eat it with a seeming relish when mixed with some more nutritious and esteened food; on which account it should enter but sparingly into mixtures.

6. Medicago sativa (Lucerne).-Fr. Lucerne; Ger. Lucerner Klee.-Stem erect, branching, smooth; flowers in racemes or clusters, generally of a purplish colour; root perennial, thick, and branching, penetrating very deep into the subsoil, sometimes ten or twelve feet; height about three feet; flowers in June and July. The cultivation of Lucerne is of unknown antiquity in Italy, Spain, and the south of France; it is likewise cultivated in Persia, and several other countries of Asia ; also in Peru, and elsewhere in South America ; in the Canadas, and the United States. In Britain it is a valuable early plant for yielding fodder before the Red Clover; and its cultivation has often been attempted, and attended with various degrees of success. Scotland is too cold for the successful growth of Lucerne. The soils which appear most congenial to it are those of a very light sandy or dry nature, as for example, those near the coast, where it is generally found to thrive well, although exposed to the direct influence of the sea breeze, and to be fit for cutting at least a fortnight earlier than common Rye Grass and Red Clover. If proper attention be paid to the young plants, as to thinning, \&c., they will yield a considerable crop the second year; but it is, at least, the third season after sowing before they arrive at full maturity; and afterwards, they will continue to produce good crops for eight years, and even more, provided they receive a good top-dressing occasionally in winter, and are kept free from couch-grass and other perennial weeds.

7. Onobrychis sativa (Common Sainfoin).-Fr. Esparcette, or Sainfoin ordinaire; Ger. Esparsette.-A leguminous plant, flowers in spikes, of a beautiful pink or flesh colour, on long foot-stalks; stems nearly upright; roots subfusiform, somewhat woody, and penetrating to a considerable depth, perennial; height two to three feet; flowers from June to August. Grows naturally in light chalky soils in various parts of England. Although a native of England, the Sainfoin is said to have been originally introduced as an agricultural plant from France; and is now considered the most important leguminous herbage and forage plant in the calcareous districts of both countries, and particularly on the poor dry thin chalky hills and downs in the South of England. A very judicious method of raising this plant, which is practised in some parts, is to sow it with about half the quantity of barley or other grain used for a full crop, which gives it the advantage of being shaded and kept moist during the first summer, without the chance of the plants being weakened from the closeness of the corn crop. In cases where the barley or corn is drilled the Sainfoin should be drilled across the field, or at right angles with the drills of the corn crop. The usual period of duration of Sainfoin, in a profitable state, is from eight to ten years in chalky soils, and seven or eight in those of a sandy or gravelly nature ; but although the plants lose a good deal of their vigour at that age, they have been known to exist for nearly a hundred years. The duration of the crop may, however, be increased by judicious top-dressing. In Scotland, the cultivation of Sainfoin has hitherto been little attended to, partly, no doubt, from an opinion that it is only suited for chalky soils; but it has been ascertained to succeed well on almost any soil, provided it be sufficiently dry, 
and particularly on such as are of a calcareous sandy nature, or are incumbent on limestone. On such of these as are too thin or dry for producing good crops of corn and grass, it may be grown with very beneficial results.

8. Petroselinum sativum (Common Parsley).-Fr. Persil ordinaire; Ger. Petersilie. -A somewhat fusiform-rooted biennial or triennial ; flowers in July; height one to three feet; colour of the flowers light yellow. Native of Sardinia, from whence it is said to have been first introduced into Britain in the year 1548 . Parsley is eaten by most of our herbivorous domesticated animals, particularly sheep; and from being believed to act as a preventive of the red-water and liver-rot in that animal, it has been recommended for sowing in their pastures. Although its biennial duration does not suit well for this purpose, it may be used in small quantities, say at the rate of about one pound to the imperial acre, when the soil is of a light and medium description; and if the pasture is not kept very bare, it will be found to ripen, and scatter a sufficient quantity of seed to perpetuate its existence. Of the numerous varieties cultivated, the common Plain-leaved is that generally employed in field culture.

9. Plantago lanceolata (Common Plaintain, or Rib Grass).-Fr. Plantain des prés; Ger. Spitzwegerich.-A fibrous-rooted perennial; flowers in May and June; leaves lanceolate, tapering towards both ends, spreading, prostrated or lying on the ground; spikes or heads dark-coloured; stems without leaves, angular, and rising to the height of twelve or eighteen inches. Grows naturally in dry pastures. The Rib Grass produces its foliage at an early period of the season, when it is eaten by cattle, sheep, and horses; on which account its mixture with grasses on dry pastures was formerly recommended and practised. It has, however, got deservedly into less repute, from its close spreading leaves occupying too great a surface, to the partial exclusion of the more profitable grasses and clovers, and also from live-stock, in general, seeming to manifest rather a dislike to its stalks and leaves, as the season becomes more advanced.

10. Poterium Sanguisorba (Common Burnet).-Fr. Pimprenelle; Ger. Pimpinelle. -A fibrous-rooted sub-perennial; height two to three feet; grows naturally on chalky pastures in England; flowers in June and July. The Burnet was formerly sown either along with, or as a substitute for, clover, amongst grass seeds, for hay or pasture, to a very great extent, in some of the chalky districts of England; but its cultivation has declined although still grown to a considerable extent. It has never been cultivated much in Scotland, nor does it seem deserving of more general encouragement, except, perhaps, in small quantities, as a mixture, on light sandy or calcareous soils, and with Lucerne and Sainfoin on sandy links.

11. Trifolium hybridum (Hybrid, or Alsike Clover).-Fr. Trefle hybride (de Suede); Ger. Schwedischer oder Bastard Klee.-Is so named from being intermediate in its appearance between the white and red clovers. Heads globular, stalked; stems branching, and in habit of growth not so upright as those of Common Red Clover ; roots fibrous, perennial; flowers in June and July. The T. hybridum is now well known as Alsike Clover. The seeds reached us originally from Sweden under this name. It is deservedly in repute as one of the best perennial clovers, and well adapted for this country. From the result of our own experiments it is found to thrive on soils which are termed by farmers clover-sick. For this quality, especially, it has proved a most valuable acquisition to our cultivated field plants, and is now used and generally approved of in all mixtures of grasses and clovers.

12. Trifolium incarnatum (Scarlet, Crimson, or Italian Clover).-Fr. Trifle incarnat; Ger. Incarnat Klee.--Spikes or heads oblong, and nodding to one side, of a beautiful bright 


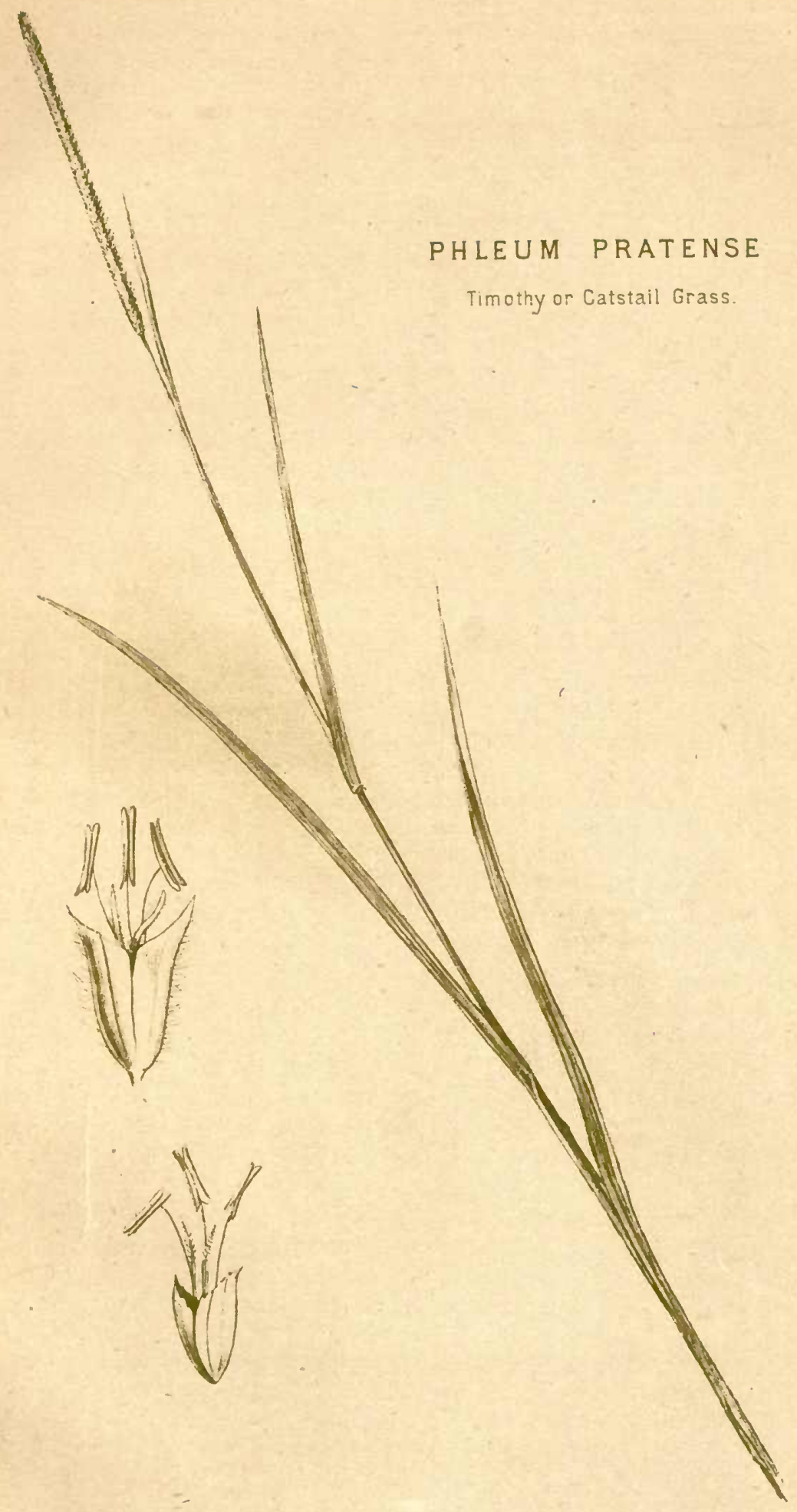



scarlet colour when in flower, stem pretty upright, much branched; the whole plant covered with short wool or hair; flowers in June and July; height eighteen inches to two feet; root annual, native of Italy. It is being grown with much success in England, particularly in the southern counties; but its culture is not attended with much success in most parts of Scotland. The advantages to be derived from the cultivation of $T$. incarnatum are, that when sown in autumn it may be cut and cleared from the ground in the beginning of June following, and the land fallowed for wheat or spring corn ; it forms a valuable green food for cattle at an early period of the season; and, if cut when in full flower, yields a more abundant crop, and makes a superior hay to that of common clovers, at least it is more readily eaten by horses. There can be no doubt that the south of England is better suited for the growth of the crimson clover than any part of Scotland, from the circumstance that the corn crops are much earlier removed: consequently the young plants have more time to attain strength before the winter season sets in. A variety of the above (T. incarnatum tardif of the French) was introduced in 1837 , the results of comparative trials with which were, that the plants came into flower when those of the coinmon were nearly over, and on being cut, their produce was fully a third heavier than any of the others.

13. Trifolium minus vel flliforme (Yellow Suckling Clover, or Trefoil).-Fr. Trifle filiforme; Ger. Gelber fadenförmiger klee. - A fibrous-rooted sub-perennial ; flowers from May to July; heads small and loose; colour of the flowers bright yellow; flower-stalks slender or flexuose; stems procumbent, leaflets scarcely having foot-stalks. This clover has been recommended for growing on very dry gravelly or rocky places, which are incapable of supporting the more valuable grasses and clovers; but, from the small bulk of produce which it yields, the propriety of its cultivation is questionable; and besides, cattle are not found to relish it if they can procure more nutritious food.' Although too small to be of much importance in pastures, it forms an agreeable mixture in lawns, especially where the soil is too dry for white clover.

14. Trifolium pratense (Common, or Rea Clover).-Fr. Trèfle violet or rouge; Ger. Rothklee.-A somewhat fusiform-rooted sub-perennial; flowers in June and July; colour generally reddish purple, but of various shades, and sometimes even nearly white. In addition to their shortness of duration, this and the rest of the biennial clovers are distinguished from the more permanent sorts by their roots being more fusiform (thick and fleshy, or carrot shaped), and by their leaves and stems being generally smoother or less hairy. That variety more particularly denominated English Red Clover is of a strong luxuriant habit of growth; its seeds are large, and of a bold purple colour. It is more particularly adapted for rather superior soils. Like the other varieties, it derives its name from the country in which it is grown; and from being often the produce of foreign seed, it, in such cases, partakes, to a certain degree, of the qualities of that particular variety from which it may have been produced. Among the other varieties may be mentioned German, Dutch, Flemish, or Belgian, French, American, and Normandy Red Clovers. The French Clover is remarkably smooth in all its parts, leaflets roundish, and altogether of a rich green succulent appearance: the seeds, which are chiefly from the southern departments of France, are small, plump, and have a considerable portion of purple in their colour. It is best suited for soils in sheltered situations. The Normandy Red Clover (Trefle de Normandy of the French) is from the north of France, of a strong luxuriant habit of growth, of a dark green colour, producing comparatively few flowers, and is some days later than the common sorts. The American variety has smaller seeds, in which the 
yellow colour is predominant, and is not quite so luxuriant in growth; its stalks are hard and small, and it is considered of more permanent duration than any of the other biennial kinds. In late years, however, some finer samples of larger and more purplish seeds have been received; these, no doubt, the produce of English or other important kinds.

15. Trifolium pratense perenne (Cow Grass, or Perennial Red Clover).-Fr. Treffe violet vivace d'Angleterre; Ger. Bullenklee.-This sort is so distinct in its general appearance from the common cultivated varieties of $T$. pratense, that some have supposed it to constitute a different species. Compared with the Common Red Clover of the fields, its flowers, foliage, and stems, are, in general, darker coloured ; leaflets narrower, and, together with the stems, much more downy or hairy, and roots more fibrous; it differs also in some other characteristics of minor importance. This sort grows naturally in old pastures, heathy moors, \&c., and presents several varieties, differing slightly in colour and in habit of growth, but retaining more or less of the narrowness and woolliness of their foliage, and all agreeing in their permanency of duration. The variety generally cultivated in this country under the above name, bears a considerable resemblance to the biennial sort in its general habits and appearance, and differs from it only in having rather more woolly leaves, in being of fully more permanent duration, and in coming into flower a few days later.

16. Trifolium repens (White, or Dutch Clover).-Fr. Trèfle blanc; Ger. Weissklee.A fibrous-rooted perennial; flowers throughout the summer months and beginning of autumn; colour of the flowers white, or sometimes tinged with very light pink; leaflets inversely heart-shaped, often having a black or darkish coloured blotch near the base; flower-stalks without leaves, upright; stem creeping on the ground and rooting at the joints. Grows naturally in pastures, in a great variety of soils and situations. It is an indispensable requisite in all pastures; but where too prevalent, has a tendency to scour cattle, besides occupying the ground which would otherwise be more profitably filled with the superior pasture grasses.

17. Ulex europæus (Common Whin, Furze, or Gorse).-Fr. Ajone; Ger. Stachelginster. - The Common Whin is too well-known to require any specific description : it has been employed for an unknown length of time in some parts of this country for feeding horses, cattle, and sheep, during the winter months. Whins are given to horses and cattle when in a green state, after undergoing a process of thrashing or bruising, until the prickles are so far reduced or deprived of their acute points, that the animals can eat them with perfect safety, or without endangering their mouths. Sheep, on the other hand, are merely turned out to feed on Whins when the snow is too deep for allowing them to get at the grass; and although they are found to fatten and thrive much better on the former, yet they seldom touch them until forced to do so from not getting at the grass. When once accustomed to the Whins, they continue to eat them in greater or less quantities, according to the state of the pasture, until the young grass comes up in the beginning of summer: hence, when Whins are plentiful in the winter pasture, shepherds always look with anxiety for a snow storm in the early part of that season. In this country the Whin will not succeed beyond 900 feet above the level of the sea; but many sheep-walks might be improved by introducing it on moors under that altitude. Some poor uplands might, also, be profitably laid down under Whins, sown broadcast, with or without a corn crop, at the rate of $20 \mathrm{lb}$. or $24 \mathrm{lb}$. per acre, to be mown annually for winter green food. The plant has been used for sowing on the tops and in the face of mud and turf fences, as a cheap and efficient hedge on dry and poor soils, where thorns will not prosper. For sow- 


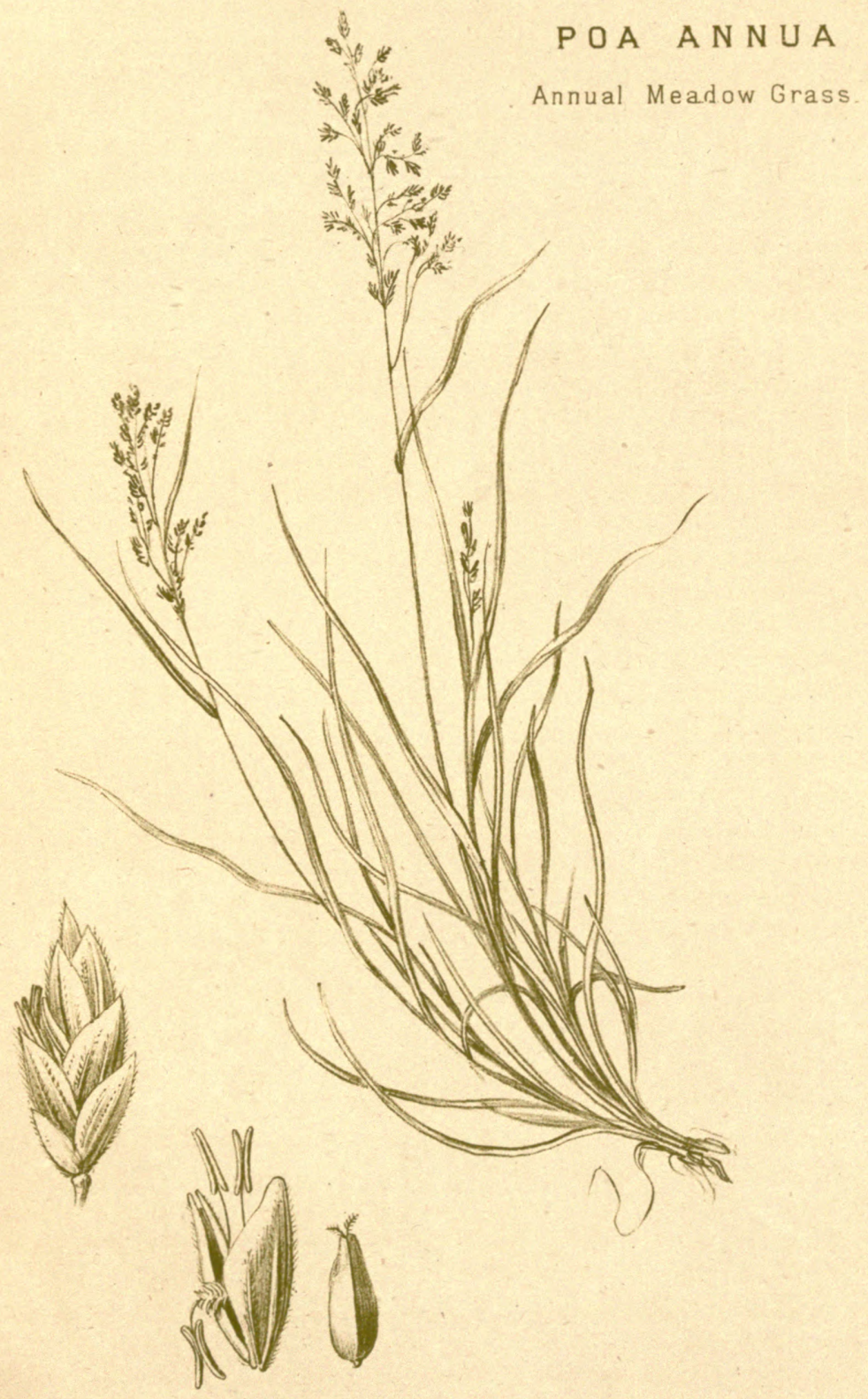



ing a single line a mile in length, $3 \mathrm{lb}$. to $4 \mathrm{lb}$. of seed will be sufficient. The DoubleFlowered Whin, a variety of the above, which is propagated by cuttings, has been recommended for hedges, where it is desirable to prevent the spreading of whin seed in the neighbouring ground.

18. Vicia sativa (Common Tare, or Vetch).-Fr. Vesce commune; Ger. Wicke.Flowers generally in pairs, without footstalks, and of a red or purplish colour; leaflets oblong, terminating abruptly, with a small point in the middle; pods more or less downy or hairy; root annual. In a wild state Vicia sativa is found (but in most parts rather scarce) growing by hedges, road-sides, and in stony places, where not very dry, as in rubbish heaps and about quarries. The wild variety, however differs from those generally cultivated, in being of much dwarfer, and of a more slender habit of growth, and also having much smoother leaves and stalks. Those sorts in general cultivation are the Common or Summer Tare, and the Winter Tare, which resemble one another in general appearance, but the latter variety is distinguished by being usually of smaller growth, and its pods being more smooth and cylindrical, containing more seeds, and in its general habit more like the wild variety. The Common or Summer Tare presents in the appearance of its seeds much diversity of size, arising from soil and culture. The larger sizes are better known in many places by the name of Vetches, whilst the smaller samples are denominated Tares, and are either sown as green food for cattle, or for their ripe seed. In the former case they are generally sown with oats or barley, and so as to come in for use between the first or second crops of grass. The practice of sowing one or other of the cereal grasses (oats or barley) amongst Tares is strongly recommended, not only as it insures a greater bulk of produce from the stems of the grains rising above the Tares, but they also serve to prevent them lying on the ground, and so becoming injured in damp weather; cattle are also fonder of the fodder in a mixed than in an unmixed state. When sown for their ripe seed, the Summer Tare is generally mixed with beans, or peas and beans, in the proportion of about a fourth part in bulk, or less, of the whole quantity of seed per acre. It has been ascertained that Winter Tares, repeatedly sown in spring, acquire more of the tender nature peculiar to the summer sort; therefore it is essential for cultivators to sow such seed as is not only the produce of the true Winter Tare, but of it sozen in autumn. When Winter Tares are cultivated for their seeds, the general practice has been to sow them alone; it may, however, be more advisable to sow them in mixture with Winter Beans,- the seeds being easily separated from the beans, when thrashed, by means of a proper sized riddle.

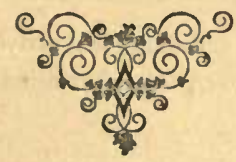


I TABLE shewing the average weight per bushel of the principal Grasses described in the preceding pages, with the average number of seeds contained in one ounce.

\begin{tabular}{|c|c|c|c|c|c|c|}
\hline NAMES OF GRASSES & 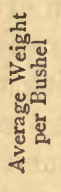 & 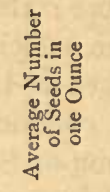 & NAMES OF GRASSES & & 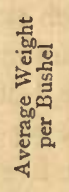 & 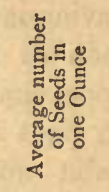 \\
\hline Agrostis alba var. stolonifera & $\begin{array}{l}1 b . \\
13\end{array}$ & 500,000 & Phalaris arundinacea ... & & $\begin{array}{l}\mathrm{Ib} . \\
48\end{array}$ & 42,000 \\
\hline $\begin{array}{llll}\text { vulgaris } & \ldots & \ldots & \ldots\end{array}$ & 12 & 425,000 & Phleum pratense & $\cdots$ & 44 & 74 \\
\hline $\begin{array}{lllll}\text { Aira cæspitosa } & \ldots & \ldots & \ldots & \ldots\end{array}$ & 14 & 132,000 & $\begin{array}{llll}\text { Poa aquatica } & \ldots & \ldots & \ldots\end{array}$ & $\ldots$ & $13 \frac{1}{4}$ & 58,000 \\
\hline $\begin{array}{llll}\text { Alopecurus pratensis } . . & \ldots & \ldots\end{array}$ & $5 \frac{1}{4}$ & 76,000 & $\begin{array}{llll}\text { fluitans } & \ldots & \ldots & \ldots\end{array}$ & $\cdots$ & $14 \frac{1}{2}$ & 33,000 \\
\hline Ammophila arundinacea $\ldots \quad \ldots$ & 15 & 10, 100 & $\begin{array}{llll}\text { nemoralis } & \ldots & \ldots & \ldots\end{array}$ & $\cdots$ & 15 & 173,000 \\
\hline Anthoxanthum odoratum ... ... & 6 & 71,000 & - sempervirens ... & $\cdots$ & $15 \frac{1}{2}$ & 133,000 \\
\hline Arrhenatherum avenaceum $\quad \ldots$ & & 21,000 & $\begin{array}{llll}\text { pratensis } & \ldots & \ldots & \ldots\end{array}$ & $\cdots$ & $13 \frac{1}{1}$ & 243,000 \\
\hline Brachypodium sylvaticum... & $10 \frac{1}{4}$ & 15,500 & $\begin{array}{lll}\ldots & \ldots & \ldots\end{array}$ & $\cdots$ & $15 \frac{1}{4}$ & 217,000 \\
\hline $\begin{array}{lllll}\text { Cynosurus cristatus } & \ldots & \ldots & \ldots\end{array}$ & 26 & 28,000 & Trisetum flavescens $\quad \ldots$ & $\ldots$ & 5 & 118,000 \\
\hline $\begin{array}{llll}\text { Dactylis glomerata } & \ldots & \ldots & \ldots\end{array}$ & $\mathrm{II} \frac{1}{2}$ & 40,000 & & & & \\
\hline $\begin{array}{llll}\text { Elymus arenarius } & \ldots & \ldots & \ldots \\
\text { geniculatus } & \ldots & \ldots & \ldots\end{array}$ & $\begin{array}{l}10 \\
12\end{array}$ & $\begin{array}{l}2,320 \\
2,300\end{array}$ & & & & \\
\hline $\begin{array}{llll}\text { Festuca duriuscula } & \ldots & \ldots & \ldots\end{array}$ & $9 \frac{\pi}{2}$ & 39,000 & & & & \\
\hline $\begin{array}{lll}\text { elatior } & \ldots & \ldots\end{array}$ & 17 & 20,500 & Achillea Millefolium & $\cdots$ & $29 \frac{1}{4}$ & 200,000 \\
\hline $\begin{array}{llll}\text { gigantea } . . . & \ldots & \ldots & \ldots\end{array}$ & I5, & 8,600 & Lotus corniculatus $\quad \ldots \quad \ldots$ & $\cdots$ & 62 & 28,000 \\
\hline 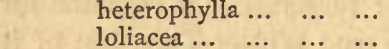 & $12 \frac{1}{2}$ & 33,000 & $\begin{array}{llll}\operatorname{lajor}_{1} & \ldots & \ldots & \ldots\end{array}$ & $\cdots$ & 64 & 51,000 \\
\hline $\begin{array}{lll}\text { loliacea } & \ldots & \ldots \\
\text { ovina } & \ldots & \ldots\end{array}$ & 15 & 24,700 & Medicago lupulina $\ldots$ & $\cdots$ & $\begin{array}{l}03 \frac{3}{4}-x-3-1 \\
60\end{array}$ & 16,000 \\
\hline ovina $\ldots . .$. & $13 \frac{1}{4}$ & 64,000 & $\begin{array}{lll}\text { sativa } & \ldots & \ldots\end{array}$ & $\cdots$ & 60 & 12,600 \\
\hline $\begin{array}{llll}\text { tenuifolia } & \ldots & \ldots \\
\text { pratensis } & \ldots & \ldots & \ldots\end{array}$ & 13 & 88,000 & $\begin{array}{lll}\text { Onobrychis sativa } & \ldots & \ldots\end{array}$ & $\cdots$ & 26 & $\begin{aligned} 1,280 \\
2\end{aligned}$ \\
\hline 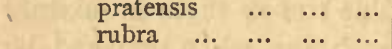 & $\begin{array}{l}16 \\
10\end{array}$ & $\begin{array}{l}26,000 \\
39,000\end{array}$ & $\begin{array}{l}\text { Petroselinum sativum } \\
\text { Plantago lanceolata ... }\end{array}$ & $\ldots$ & $\begin{array}{l}41 \\
51 \frac{1}{2}\end{array}$ & $\begin{array}{l}12,000 \\
15,600\end{array}$ \\
\hline $\begin{array}{lllll}\text { Holcus lanatus } & \ldots & \ldots & \ldots & \ldots\end{array}$ & 7 & 95,000 & Poterium Sanguisorba & $\ldots$ & $24 \frac{1}{2}$ & 3,320 \\
\hline $\begin{array}{lllll}\text { mollis } & \ldots & \ldots & . . & \ldots\end{array}$ & 6 & 85,000 & Trifolium minus vel filiforme & $\ldots$ & $64 \frac{1}{2}$ & 54,000 \\
\hline $\begin{array}{llll}\text { Lolium italicum } \ldots & \ldots & \ldots & \ldots\end{array}$ & 17 & 27,000 & hybridum $\quad \ldots \quad \ldots$ & $\ldots$ & 65 & 34,000 \\
\hline perenne, light-seeded ... & 18 & $16, \infty 00$ & pratense & -1 & 64 & 16,000 \\
\hline $\begin{aligned} \begin{array}{r}\text { perenne, heavy } \\
\text { Milium effusum }\end{array} & \ldots\end{aligned}$ & 27 & 13,000 & perenne... & ... & 64 & 16,000 \\
\hline Milium effusum ... & 25 & 95,000 & epens $\quad \cdots \quad \cdots$ & $\ldots$ & & 32,000 \\
\hline
\end{tabular}

** As the number of seeds which will germinate and arrive at maturity in a given quantity, is dependent, in a great measure, on the depth of cover, for information on this point experimentalists are referred to the Table at page II. 


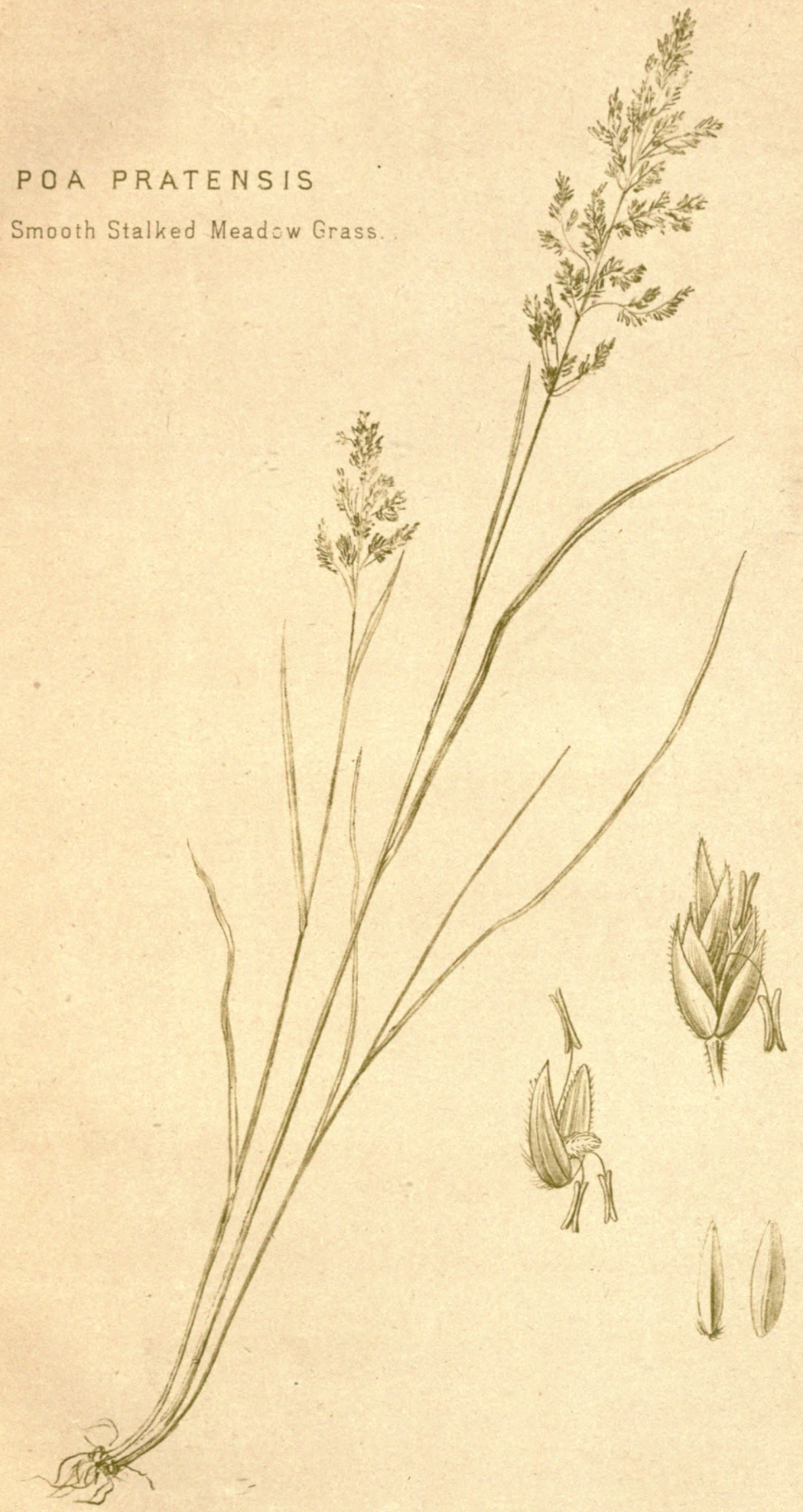





\section{ENGLISH NAMES OF GRASSES}

\section{I.-NATURAL GRASSES}

Alpine Meadow Grass ...

Annual Meadow Grass ...

Bent Grass, Marsh

$$
\text { , Black }
$$

Bearded Soft Grass

Black Switch Grass

Brome Grass, Giant

Catstail Grass

Cocksfoot Grass, Common Rough

Creeping-rooted Bent

$\begin{array}{ll}, & \text { Fescue Grass ... } \\ , & \text { Grass of Suffolk } \\ , & \text { Soft Grass }\end{array}$

Crested Dogstail Grass ...

Darnel

Devon Evers ... ...

Dogstail Grass

Evergreen Meadow Grass

Fescue Grass, Creeping

\section{Darnel Spiked}

Fine-leaved

Giant Wood

Hard

Meadow ...

Red

Sheep's

Slender

Tall Meadow

Various-leaved

Wood

Fibrous-rooted Tall Oat-like Grass

Fiorin Grass

Fine-leaved Fescue Grass

Floating Sweet Water or Meadow Grass

Foxtail Grass

French" Rye Grass

Field

Giant Wood Fescue or Brome Grass ...

Gold Grass or Dogstail ..

Hair Grass, Tufted

Hard Fescue Grass

Hudson's Bay Meadow Grass ...

Italian Rye Grass

Knee-jointed, or Pendulous Sea Lyme Grass

Knot Grass

Marrum
.. See Poa alpina ...

... - Poa annua

1.. - Agrostis alba

... - Alopecurus agrestis

... - Holcus mollis

... - Agrostis vulgaris

... - Festuca gigantea

.. - Phleum pratense

... - Dactylis glomerata

... - Agrostis vulgaris

... - Festuca rubra

... - Agrostis vulgaris

... - Holcus mollis

... - Cynosurus cristatus

... - Festuca loliacea

... - Lolium perenne

... - Cynosurus cristatus ...

... - Poa nemoralis var. sempervirens ..

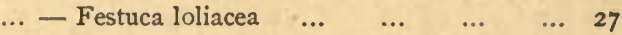

... - Festuca ovina var. tenuifolia $\quad \ldots \quad \ldots 27$

$\begin{array}{lllllll}\text {... - Festuca gigantea } & \ldots & \ldots & \ldots & \ldots & 26\end{array}$

$\begin{array}{llllll}\text {... } & \text { - Festuca duriuscula ... } & \ldots & \ldots & \ldots & 26\end{array}$

$\begin{array}{llllll}\ldots & - \text { Festuca pratensis } \quad \ldots & \ldots & \ldots & \ldots & 27\end{array}$

$\begin{array}{llllll}\ldots & \text {.. Festuca rubra } \quad \ldots & \ldots & \ldots & \ldots & 28\end{array}$

$\begin{array}{llllll}\text {... }- \text { Festuca ovina } & \ldots & \ldots & \ldots & \ldots & 27\end{array}$

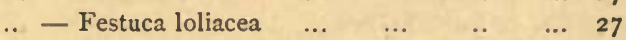

$\begin{array}{llllll}\text {... - Festuca elatior } & \ldots & \ldots & \ldots & \ldots & 26\end{array}$

$\begin{array}{llllll}\text {.. - Festuca heterophylla } & \ldots & \ldots & \ldots & 27\end{array}$

... - Brachypodium sylvaticum ... $\quad \ldots \quad \ldots \quad$... 24

... - Arrhenatherum avenaceum $\quad \ldots \quad \ldots 24$

... - Agrostis alba var. latifolia $\quad \ldots \quad \ldots \quad 22$

$\begin{array}{lllll}\ldots \text {-.. Festuca ovina var. tenuifolia } \quad \ldots & \ldots & 27\end{array}$

... - Poa fluitans ... $\quad \ldots \quad$... $\quad \ldots \quad \ldots \quad 3$ I

$\begin{array}{llllll}\ldots & \text { - Alopecurus pratensis } \quad \ldots & \ldots & \ldots & 23\end{array}$

... - Alopecurus agrestis $\quad \ldots \quad \ldots . \quad \ldots \quad 23$

... - Arrhenatherum avenaceum $\quad$.. $\quad \ldots \quad 24$

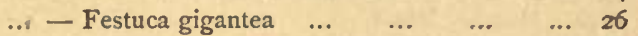

$\begin{array}{llllll}\ldots-\text { Cynosurus cristatus ... } & \ldots & \ldots & \ldots & 24\end{array}$

$\begin{array}{lllllll}\ldots \text {-. Aira crespitosa } & \ldots & \ldots & \ldots & \ldots & 23\end{array}$

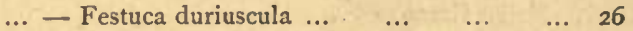

... - Poa nemoralis var. sempervirens ... $\quad \ldots \quad 32$

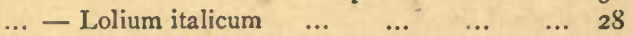

$\begin{array}{llllll}\ldots & \text { - Elymus geniculatus } & \ldots & \ldots & \ldots & 26\end{array}$

... - Arrhenatherum avenaceum $\quad \ldots \quad \ldots .24$

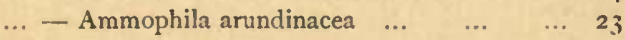


Marsh Bent Grass

Mat Grass

Meadow Grass, Alpine ... Annual ...

Evergreen

Floating Sweet

Hudson's Bay

Rough-stalked

Smooth-stalked

Stoloniferous

Water ...

Wood ..

Meadow Fescue Grass .. Foxtail Grass ...

, ," Tall

Millet Grass

Oat Grass, or Oat-like Grass ,Yellowish

Orchard Grass $\quad \ldots \quad \ldots$

Purple Bent $\quad \ldots \quad$... $\quad .$.

Quick Grass

Red Fescue Grass

Reed-like Canary Grass

Reedy Water Grass

Rough-stalked Meadow Grass ...

Rye Grass, Common Perennial

Sand Sea Lyme Grass ..

Sea Reed

Sheep's Fescue Grass

Slender Foxtail Grass

\section{Fescue Grass}

Smooth-stalked Meadow Grass

Soft Grass

Spiked Rye-Grass-like Fescue ..

Squitch, or Twitch Grass

Stoloniferous Meadow Grass

Suffolk Creeping Grass

Sweet-Scented Vernal Grass

Tall Meadow Fescue Grass

,, Oat-like Grass

Timothy Grass

Tussac Grass

Upright Sea Lyme Grass

Various-leaved Hard Fescue Grass

Water-Grass, Floating ..

, Meadow Grass

Wood Fescue Grass

, Meadow Grass

, Millet Grass

" Wheat Grass

Woolly Soft Grass

Yellowish Oat Grass

Yorkshire Fog
... See Agrostis alba

$\begin{array}{lllll}\ldots & \ldots & \ldots & \ldots & 22\end{array}$

$\begin{array}{lllll}\text { - Ammophila arundinacea } & . . & \ldots & \ldots & 23\end{array}$

$\begin{array}{llllllll}\ldots & \text { - Poa alpina } & \ldots & \ldots & \ldots & \ldots & \ldots & 30\end{array}$

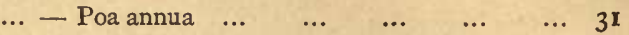

... - Poa nemoralis var. sempervirens ... ... 32

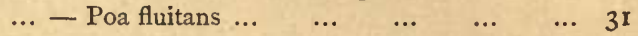

... - Poa nemoralis var. sempervirens ... $\quad \ldots \quad 32$

$\begin{array}{lllllll}\text {... - Poa trivialis ... } & \ldots & \ldots & \ldots & \ldots & 32\end{array}$

$\begin{array}{lllllll}\ldots \text {-. Poa pratensis } \quad \ldots & \ldots & \ldots & \ldots & 32\end{array}$

$\begin{array}{lllllll}\ldots & \text { - Poa trivialis } \ldots & \ldots & \ldots & \ldots & \ldots & 32\end{array}$

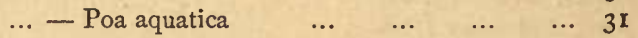

$\begin{array}{llllll}\ldots \text {... Poa nemoralis } \quad \ldots & \ldots & \ldots & \ldots & 3 \text { I }\end{array}$

$\begin{array}{llllll}\ldots \text {.. } & \text { Festuca pratensis } \ldots & \ldots & \ldots & \ldots & 27\end{array}$

... - Alopecurus pratensis $\quad \ldots \quad \ldots \quad \ldots \quad \ldots 3$

$\begin{array}{llllll}\ldots \text {.. Festuca elatior } & \ldots & \ldots & \ldots & \ldots & 26\end{array}$

$\begin{array}{llllll}\ldots & \text {.. Holcus lanatus } \quad \ldots & \ldots & \ldots & \ldots & 28\end{array}$

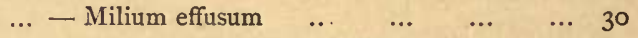

... - Arrhenatherum avenaceum $\quad \ldots \quad$... 24

$\begin{array}{lllll}\ldots \text {.. Trisetum flavescens } \quad \ldots & \ldots & \ldots & 32\end{array}$

$\begin{array}{llllll}\ldots \text {.. } & \text { - Dactylis glomerata } & \ldots & \ldots & \ldots & 25\end{array}$

$\begin{array}{lllllll}\ldots \text { - }- \text { Agrostis vulgaris } & \ldots & \ldots & \ldots & \ldots & 22\end{array}$

$\begin{array}{lllllll}\text {... - Agrostis vulgaris } & \ldots & \ldots & \ldots & \ldots & 22\end{array}$

$\begin{array}{lllllll}\ldots \text { - Festuca rubra } & \ldots & \ldots & \ldots & \ldots & 28\end{array}$

... - Phalaris arundinacea $\quad \ldots . \quad \ldots . \quad \ldots \quad 30$

$\begin{array}{lllllll}\ldots & \text { - Poa aquatica } & \ldots & \ldots & \ldots & \ldots & 3 \text { I }\end{array}$

$\begin{array}{lllllll}\ldots & \text { - Poa trivialis } & \ldots & \ldots & \ldots & \ldots & 32\end{array}$

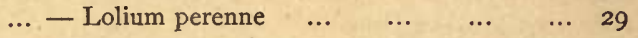

$\begin{array}{lllllll}\ldots & \text {-. Elymus arenarius } & \ldots & \ldots & \ldots & \ldots & 25\end{array}$

... - Ammophila arundinacea $\ldots . \quad \ldots \quad$... 23

$\begin{array}{lllllll}\ldots & \text { - Festuca ovina } \quad \ldots & \ldots & \ldots & \ldots & 27\end{array}$

$\begin{array}{llllll}\ldots \text {-. Alopecurus agrestis } \quad \ldots & \ldots & \ldots & 23\end{array}$

$\begin{array}{lllllll}\ldots & \text { - Festuca loliacea } \quad \ldots & \ldots & \ldots & \ldots & 27\end{array}$

$\begin{array}{lllllll}\ldots & \text { - Poa pratensis } \quad \ldots & \ldots & \ldots & \ldots & 32\end{array}$

$\begin{array}{llllll}\ldots & \text { - Holcus lanatus } \quad \ldots & \ldots & \ldots & \ldots & 28\end{array}$

$\begin{array}{llllll}\text {... - Festuca loliacea } & \ldots & \ldots & \ldots & \ldots & 27\end{array}$

$\begin{array}{lllllll}\ldots & \text { - Agrostis vulgaris } & \ldots & \ldots & \ldots & \ldots & 22\end{array}$

$\begin{array}{lllllll}\ldots & \text { - Poa trivialis } & \ldots & \ldots & \ldots & \ldots & 32\end{array}$

$\begin{array}{lllllll}\ldots & \text { - Agrostis vulgaris } & . & \ldots & \ldots & \ldots & 22\end{array}$

... - Anthoxanthum odoratum ... $\quad \ldots \quad$... 23

$\begin{array}{lllllll}\text {... - Festuca elatior } & \text {... } & \ldots & \ldots & \ldots & 26\end{array}$

... - Arrhenatherum avenaceum $\quad \ldots \quad \ldots 24$

$\begin{array}{lllllll}\ldots & \text { - Phleum pratense } & \ldots & \ldots & \ldots & \ldots & 30\end{array}$

$\begin{array}{llllll}\text {... - Dactylis cæspitosa } & \ldots & \ldots & \ldots & \ldots & 25\end{array}$

$\begin{array}{lllllll}\ldots & \text { - Elymus arenarius } & \ldots & \ldots & \ldots & \ldots & 25\end{array}$

... - Festuca heterophylla $\quad \ldots \quad \ldots \quad \ldots \quad \ldots \quad 27$

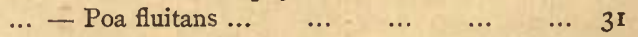

$\begin{array}{llllll}\ldots \text {... Poa aquatica } & . & \ldots & \ldots & \ldots & 3 \mathbf{r}\end{array}$

... - Brachypodium sylvaticum ... $\quad \ldots \quad \ldots .24$

$\begin{array}{llllll}\text {... - Poa nemoralis } \quad \ldots & \ldots & \ldots & \ldots & 3 \mathrm{r}\end{array}$

$\begin{array}{lllllll}\text {... - - Milium effusum } \quad \ldots & \ldots & \ldots & \ldots & 30\end{array}$

... - Brachypodium sylvaticum ... $\quad$... $\quad \ldots \quad 24$

$\begin{array}{lllllll}\ldots & \text { - Holcus lanatus } & \ldots & \ldots & \ldots & \ldots & \\ \end{array}$

$\begin{array}{llllll}\ldots & \text { - Trisetum flavescens } \quad \ldots & \ldots & \ldots & 32\end{array}$

$\begin{array}{lllllll}\text {.. } & \text { - Holcus lanatus } & \ldots & \ldots & \ldots & \ldots & 28\end{array}$ 


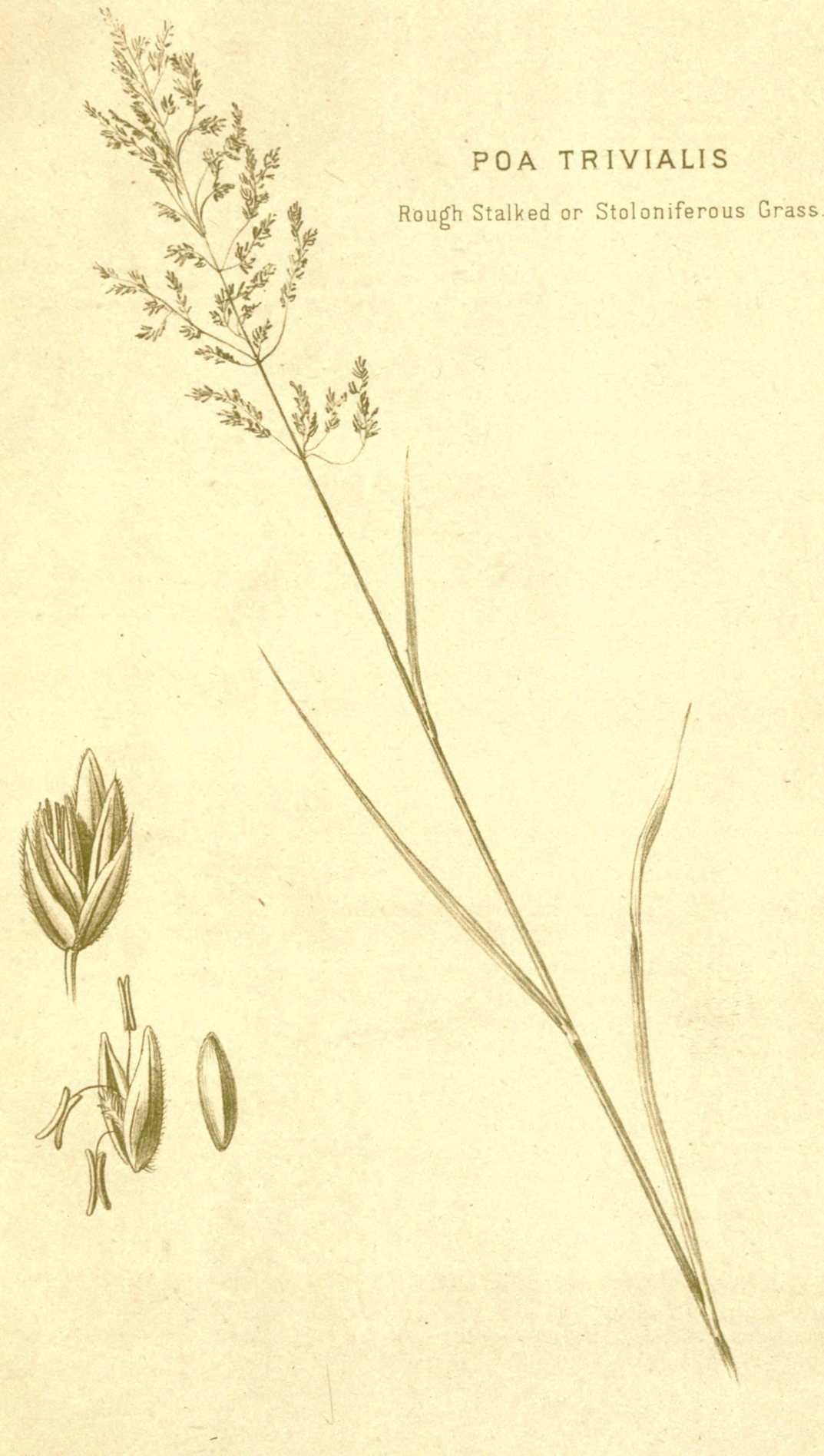





\section{II.-ARTIFICIAL GRASSES}

Birdsfoot Trefoil

\begin{tabular}{|c|c|c|c|}
\hline \multirow{2}{*}{\multicolumn{2}{|c|}{ Black Medick }} & \multicolumn{2}{|c|}{ Greater } \\
\hline & & $\ldots$ & $\ldots$ \\
\hline Broom & $\ldots$ & $\ldots$ & $\ldots$ \\
\hline Burnet & ... & $\ldots$ & $\ldots$ \\
\hline Clover, & , Alsike & $\ldots$ & $\ldots$ \\
\hline , & Crimson & n ... & $\ldots$ \\
\hline ," & Dutch V & White & $\ldots$ \\
\hline , & Hybrid & $\ldots$ & $\ldots$ \\
\hline ", & Italian & .. & $\ldots$ \\
\hline , & Red & $\ldots$ & $\ldots$ \\
\hline ," & Per & erennial & ... \\
\hline , & Scarlet & ... & $\ldots$ \\
\hline ," & White & $\ldots$ & $\ldots$ \\
\hline ", & Yellow & $\cdots$ & \\
\hline , & ", & Suc & ng \\
\hline
\end{tabular}

French Finger Grass ...

Furze

Gorse

Hop Trefoil

Lady Finger Grass

Lucerne

Lupuline ...

Milfoil

Nonsuch

Parsley

Plaintain ...

Rib Grass

Sainfoin ...

Tare

Vetch

Whin

$\cdots$

Yellow Trefoil

, Suckling Trefoil

... See Lotus corniculatus ... $\quad \ldots \quad \ldots . \quad \ldots \quad$ PAGE

$\begin{array}{lllllll}\text {... - Lotus major } \quad \ldots & \ldots & \ldots & \ldots & 34\end{array}$

$\begin{array}{llllll}\text {.. - Medicago lupulina ... } & \ldots & \ldots & \ldots & \ldots & 34\end{array}$

... - Cytisus scoparius ... $\quad$.. $\quad$.. $\quad \ldots \quad$.. 34

... - Poterium Sanguisorba $\quad \ldots \quad \ldots \quad \ldots \quad \ldots \quad 36$

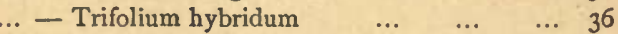

$\begin{array}{llllll}\text { - Trifolium incarnatum } & \ldots & \ldots & \ldots & 36\end{array}$

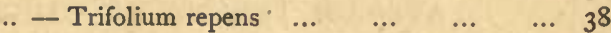

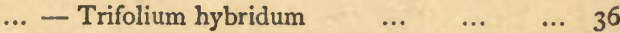

... - Trifolium incarnatum $\quad \ldots \quad \ldots \quad \ldots \quad \ldots \quad 36$

$\begin{array}{llllll}\text {... } & - \text { Trifolium pratense ... } & \ldots & \ldots & \ldots & 37\end{array}$

... - Trifolium pratense perenne $\quad$.. $\quad \ldots \quad 3^{8}$

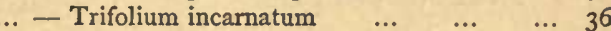

$\begin{array}{lllllll}\ldots & \text { - Trifolium repens } & \ldots & \ldots & \ldots & \ldots & 3^{8}\end{array}$

... - Medicago lupulina ... $\quad \ldots \quad$.. $\quad$ - $\quad \ldots \quad 34$

... - Trifolium minus vel filiforme $\quad$.. $\quad \ldots \quad 37$

... - Trifolium pratense perenne $\quad$.. $\quad \ldots .38$

$\begin{array}{llllll}\text {... - Onobrychis sativa } & \ldots & \ldots & \ldots & \ldots & 35\end{array}$

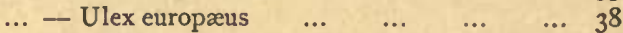

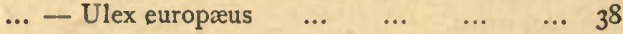

$\begin{array}{lllllll}\text {... } & \text { - Medicago lupulina ... } & \ldots & \ldots & \ldots & 34\end{array}$

$\begin{array}{lllllll}\text {... - Lotus comiculatus ... } & \ldots & \ldots & \ldots & 34\end{array}$

$\begin{array}{lllllll}\text {... - Medicago sativa } & \text {. } & \ldots & \ldots & \ldots & \ldots & 35\end{array}$

$\begin{array}{llllll}\text {... }- \text { Medicago lupulina ... } & \ldots & \ldots & \ldots & 34\end{array}$

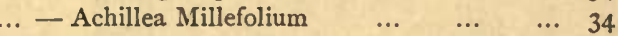

$\begin{array}{llllll}\text {... } & \text { - Medicago lupulina ... } & \ldots & \ldots & \ldots & 34\end{array}$

$\begin{array}{llllll}\text {... - Petroselinum sativum } & \ldots & \ldots & \ldots & 36\end{array}$

... - Plantago lanceolata $\quad$. $\quad \ldots \quad \ldots 3^{6}$

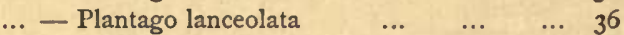

$\begin{array}{lllllll}\text {... } & - \text { - Onobrychis sativa } & \ldots & \ldots & \ldots & \ldots & 35\end{array}$

$\begin{array}{lllllll}\ldots & \text { - Vicia sativa } & \ldots & \ldots & \ldots & \ldots & 39\end{array}$

$\begin{array}{lllllll}\text {... - Vicia sativa } & \ldots & \ldots & \ldots & \ldots & 39\end{array}$

$\begin{array}{llllll}\ldots & \text { - Ulex europæus } \quad \ldots & \ldots & \ldots & \ldots & 38\end{array}$

... - $\begin{array}{llllll} & \text { - Achillea Millefolium } \quad \ldots & \ldots & \ldots & 34\end{array}$

... - Medicago lupulina ... $\quad \ldots \quad$... $\quad \ldots \quad 34$

... - Trifolium minus vel filiforme $\quad . . \quad \ldots \quad$.. 37

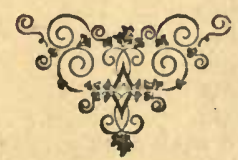


CULTIVATED GRASSES

\title{
IN THE ORDER OF THEIR FLOWERING
}

\author{
AND
}

\begin{abstract}
AVERAGE PERIODS AT WHICH THEY RIPEN THEIR SEEDS
\end{abstract}

\begin{tabular}{|c|c|c|c|c|c|c|c|c|c|c|c|}
\hline NAMES OF & GR & ASSE & & & & $\begin{array}{l}\text { Time of } \\
\text { Flowering }\end{array}$ & & & $\begin{array}{l}\text { Time of Ripening } \\
\text { the Seed }\end{array}$ & & Page \\
\hline Dactylis cæespitos & & & $\ldots$ & & First weel & $\mathrm{k}$ of Marcl & & & First week of June ... & & 25 \\
\hline Anthoxanthum of & dorat & & $\ldots$ & $\ldots$ & Second w & veek of $A p$ & & $\ldots$ & Fourth week of May & $\ldots$ & 23 \\
\hline Alopecurus prate & nsis & & $\ldots$ & $\ldots$ & Fourth we & reek of $\mathrm{Apr}$ & & $\ldots$ & Third week of June & .. & 23 \\
\hline Poa annua .... & $\ldots$ & & .. & ... & The whol & le Summer & & $\cdots$ & The whole Summer & . & $3 \mathbf{I}$ \\
\hline Poa pratensis & $\ldots$ & $\ldots$ & $\ldots$ & $\ldots$ & First weel & $\mathrm{k}$ of June & $\ldots$ & $\ldots$ & First week of July ... & $\ldots$ & 32 \\
\hline , alpina ... & $\ldots$ & & $\ldots$ & $\ldots$ & Ditto & & & $\ldots$ & $\begin{array}{lllll}\text { Ditto } & \ldots & \ldots & \ldots & \ldots\end{array}$ & $\ldots$ & 30 \\
\hline Festuca ovina & $\ldots$ & & $\ldots$ & & Second $w$ & reek of Jun & & $\ldots$ & $\begin{array}{llll}\text { Ditto } & \ldots & \ldots & \ldots\end{array}$ & $\ldots$ & 27 \\
\hline ", duriuscule & & & $\ldots$ & $\ldots$ & Ditto & ... $\quad \ldots$ & ... & $\ldots$ & $\begin{array}{lllll}\text { Ditto } & \ldots & \ldots & \ldots & \ldots \\
\end{array}$ & $\ldots$ & 26 \\
\hline rubra & & & $\ldots$ & $\ldots$ & Ditto & .. $\quad \ldots$ & & $\ldots$ & $\begin{array}{lllll}\text { Ditto } & \ldots & \ldots & \ldots & \ldots\end{array}$ & $\ldots$ & 28 \\
\hline Dactylis glomerat & & $\ldots$ & $\ldots$ & $\ldots$ & Ditto & $\ldots \quad \ldots$ & $\ldots$ & $\ldots$ & Third week of August ... & $\ldots$ & 25 \\
\hline Lolium perenne & $\ldots$ & & $\ldots$ & $\ldots$ & Ditto & $\ldots \quad \ldots$ & $\ldots$ & $\ldots$ & Second week of July & $\ldots$ & 29 \\
\hline , , , & ar. $\mathrm{t}$ & tenue & ... & $\ldots$ & Ditto & $\ldots \quad \ldots$ & $\ldots$ & $\ldots$ & $\begin{array}{lllll}\text { Ditto } & \ldots & \ldots & \ldots & \ldots\end{array}$ & $\ldots$ & 30 \\
\hline italicum & $\ldots$ & $\ldots$ & $\cdots$ & & Ditto & $\ldots$ & $\ldots$ & $\ldots$ & $\begin{array}{lllll}\text { Ditto } & \ldots & \ldots & \ldots & \ldots\end{array}$ & $\ldots$ & 28 \\
\hline Poa trivialis ... & $\ldots$ & $\ldots$ & $\ldots$ & $\ldots$ & Third we & ek of June & e... & $\ldots$ & $\begin{array}{lllll}\text { Ditto } & \ldots & \ldots & \ldots & \ldots\end{array}$ & $\ldots$ & 32 \\
\hline ", nemoralis & $\ldots$ & $\ldots$ & $\ldots$ & $\ldots$ & Ditto & $\ldots \quad \ldots$ & $\ldots$ & $\ldots$ & Fourth week of July & $\ldots$ & 31 \\
\hline " var. & sem & apervi & rirens & & Ditto & $\begin{array}{ll}\ldots & \ldots \\
\ldots & \ldots\end{array}$ & $\ldots$ & $\ldots$ & $\begin{array}{ccccc} & \\
\text { Ditto } & \ldots & \ldots & \ldots & \ldots\end{array}$ & $\ldots$ & 32 \\
\hline , fluitans ... & $\ldots$ & & $\ldots$ & & Ditto & $\ldots$ & $\ldots$ & $\ldots$ & $\begin{array}{lllll}\text { Ditto } & \ldots & \ldots & \ldots & \ldots\end{array}$ & $\ldots$ & $3 \mathbf{I}$ \\
\hline Phleum pratense & $\ldots$ & $\ldots$ & $\ldots$ & $\cdots$ & Ditto & $\ldots \quad .$. & $\ldots$ & $\ldots$ & $\begin{array}{llll}\text { Ditto } & \ldots & \ldots & \ldots\end{array}$ & $\ldots$ & 30 \\
\hline Milium effusum & $\ldots$ & $\ldots$ & $\ldots$ & $\ldots$ & Ditto & $\ldots$ & $\ldots$ & $\ldots$ & Second week of August & $\ldots$ & 30 \\
\hline Arrhenatherum a & venac & ceum & ... & $\ldots$ & Ditto & & $\ldots$ & $\ldots$ & Third week of July & $\ldots$ & 24 \\
\hline Festuca heteroph & ylla & $\ldots$ & $\ldots$ & $\ldots$ & Fourth we & reek of Jun & & $\ldots$ & Second week of August & & 27 \\
\hline Alopecurus agres & & $\ldots$ & $\ldots$ & $\ldots$ & First weel & of July & $\ldots$ & $\ldots$ & First week of October ... & $\ldots$ & 23 \\
\hline Brachypodium sy & lvatic & cum & $\ldots$ & $\ldots$ & Ditto & $\ldots \quad \ldots$ & .. & $\ldots$ & Fourth week of July & $\ldots$ & 24 \\
\hline Agrostis vulgaris & $\ldots$ & & ... & & Ditto & $\ldots \quad \ldots$ & $\ldots$ & $\ldots$ & Second week of August & $\ldots$ & 22 \\
\hline Holcus lanatus & $\ldots$ & $\ldots$ & $\ldots$ & $\ldots$ & Ditto & $\ldots \quad \ldots$ & $\ldots$ & $\ldots$ & Third week of July & $\ldots$ & 28 \\
\hline Festuca pratensis & & $\ldots$ & $\ldots$ & $\ldots$ & Ditto & $\ldots \quad \ldots$ & $\ldots$ & $\ldots$ & First week of August .. & $\ldots$ & 27 \\
\hline & & $\ldots$ & & $\ldots$ & Ditto & & $\ldots$ & $\ldots$ & Ditto .. & $\ldots$ & 26 \\
\hline Cynosurus cristat & & $\ldots$ & $\ldots$ & .. & Ditto & $\ldots \quad \ldots$ & & $\ldots$ & Ditto & $\ldots$ & 24 \\
\hline Elymus geniculat & & $\ldots$ & $\ldots$ & $\ldots$ & Second w & veek of July & & $\ldots$ & First week of August & $\ldots$ & 26 \\
\hline arenarius & & $\cdots$ & $\ldots$ & $\ldots$ & Ditto & & .. & $\ldots$ & Fourth week of August ... & $\ldots$ & 25 \\
\hline Trisetum flavesce & & $\ldots$ & $\ldots$ & $\ldots$ & Ditto & $\ldots \quad \ldots$ & $\ldots$ & $\ldots$ & Second week of August & $\ldots$ & 32 \\
\hline Ammophila arun & dinac & & $\ldots$ & $\ldots$ & Ditto & $\ldots \quad \ldots$ & $\ldots$ & $\ldots$ & $\begin{array}{lllll}\text { Ditto } & \ldots & \ldots & \ldots & \ldots\end{array}$ & $\ldots$ & 23 \\
\hline Phalaris arundina & cea & $\ldots$ & $\ldots$ & $\ldots$ & Ditto & $\ldots \quad \ldots$ & $\cdots$ & $\ldots$ & $\begin{array}{lll}\ldots & \ldots & \ldots\end{array}$ & $\ldots$ & 30 \\
\hline Agrostis alba ... & $\ldots$ & $\ldots$ & $\ldots$ & $\ldots$ & Ditto & $\ldots \quad \ldots$ & ... & $\ldots$ & Third week of August ... & $\ldots$ & 22 \\
\hline ica ... & $\ldots$ & $\ldots$ & $\ldots$ & .. & Ditto & .. $\quad \ldots$ & $\ldots$ & $\ldots$ & Second week of August & $\ldots$ & $3 \mathbf{I}$ \\
\hline Fest & $\ldots$ & $\cdots$ & .. & $\ldots$ & Ditto & $\ldots$ & $\ldots$ & $\ldots$ & $\ldots \quad \ldots \quad \ldots$ & $\ldots$ & 27 \\
\hline Hol & $\ldots$ & $\ldots$ & ".. & $\ldots$ & Ditto & & $\ldots$ & $\ldots$ & $\begin{array}{lll}\ldots & \ldots & \ldots \\
\ldots & \ldots & \ldots\end{array}$ & $\ldots$ & 28 \\
\hline Agrostis alba var & stol & lonife & & . & Third wee & ek of July & ... & $\ldots$ & Third week of August ... & $\ldots$ & 23 \\
\hline spitosa & $\ldots$ & $\ldots$ & $\ldots$ & $\ldots$ & Ditto & ... $\quad \ldots$ & $\ldots$ & $\ldots$ & Second week of September & $\ldots$ & 23 \\
\hline Festuca gigantea & $\ldots$ & $\ldots$ & $\ldots$ & $\ldots$ & Ditto & $\therefore \quad \ldots$ & $\ldots$ & $\ldots$ & Fourth week of August ... & $\ldots$ & 26 \\
\hline
\end{tabular}





